Budapesti Corvinus Egyetem

Általános és Kvantitatív Közgazdaságtan Doktori Iskola

\title{
Stabil halmazok hozzárendelési játékokban
}

Doktori értekezés

Témavezetők: Solymosi Tamás, Tasnádi Attila

Bednay Dezső

Budapest 2019 



\section{Tartalomjegyzék}

\begin{tabular}{ll}
\hline Bevezetés & 1
\end{tabular}

1. Stabil halmazok és hozzárendelési játékok 3

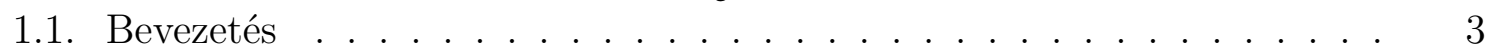

1.2. A mag stabilitása . . . . . . . . . . . . . . . . . . . . . . . . 13

1.3. Háló tulajdonság és következményei . . . . . . . . . . . . . . . . . . . . 19

1.4. Stabil halmaz létezése . . . . . . . . . . . . . . . . . . . . . . . 23

2. A stabil halmazok karakterizációja $\quad 34$

2.1. Karakterizációl. . . . . . . . . . . . . . . . . . . . . . . . . . . . . . . . . .

2.2. A karakterizáció következményei . . . . . . . . . . . . . . . . . . . 53

\begin{tabular}{ll}
\hline 3. & 69
\end{tabular}

3.1. Stabil halmazok megadása . . . . . . . . . . . . . . . . . . . . . . 69

3.2. Kapcsolat a határhozzájárulás vektorokkal . . . . . . . . . . . . . . . . 74

\begin{tabular}{ll}
\hline 4. Alkuegyensúly & 78
\end{tabular}

4.1. Az alkujáték . . . . . . . . . . . . . . . . . . . . . 80

4.2. Kapcsolat a stabil halmazokkal . . . . . . . . . . . . . . . . . . . . . . 82

\begin{tabular}{|ll}
\hline 5. Többoldalú hozzárendelési játékok & 87
\end{tabular}

5.1. Definíciók . . . . . . . . . . . . . . . 87

5.2. A mag stabilitása . . . . . . . . . . . . . . . . . . . . . . . . . . . . . . . . . . . . . . . . . .

5.3.2+2+2-es eset . . . . . . . . . . . . . . . . . . . . . . . . . . . . . . . 91

\begin{tabular}{|l|l}
\hline Ábrák jegyzéke & 95
\end{tabular}

\begin{tabular}{lr}
\hline Hivatkozások & 96
\end{tabular} 


\section{Bevezetés}

\section{A dolgozat felépítése}

A dolgozat öt fejezetből áll és a kooperatív játékelmélet egyik első megoldáskoncepciójával a stabil halmazokkal foglalkozik a hozzárendelési játékok osztályán. Az 1. fejezetben bemutatjuk az állítások kimondásához szükséges definíciókat, ismertetjük a vonatkozó irodalmat, valamint néhány, a témában született eredményre (Solymosi \& Raghavan, 2001; Núñez \& Rafels, 2013) adunk új, egyszerübb bizonyítást.

A másik négy fejezet mindegyike már egy-egy új eredményre épül. A 2. fejezetben található dolgozatnak a legfontosabb része. Az előző fejezetben található új bizonyítások mintájára megadjuk a stabil halmazok egy karakterizációját a hozzárendelési játékok osztályán. Az első fejezetben található bizonyítások igazából ezt a tételt készítik elö. A fejezet második részében (valamint majd a következő két fejezetben is) ennek a karakterizációnak a következményeivel foglalkozunk. Megmutatjuk, hogy hogyan következnek belőle, nagyon egyszerüen az előző fejezet tételei, valamint kimondunk több új, a stabil halmazok tulajdonságaival kapcsolatos eredményt is.

A 3. fejezetben a hozzárendelési játékoknak egy részosztályával az 1-eladós hozzárendelési játékokkal foglalkozunk. Ezen osztályon az előző fejezetbeli eredményeknél többet is tudunk mondani a stabil halmazokról. Itt konkrétan megadjuk az összes stabil halmazt, mint bizonyos tulajdonságú görbéket. Valamint megadjuk a kapcsolatukat a kooperatív játékelmélet egy fontos fogalmával, a határhozzájárulás vektorokkal. Ebben a fejezetben mutatjuk be a Bednay (2014) cikk eredményeit. A bizonyítás egy kicsit eltér a cikkbeliekhez képest, mert a cikkel ellentétben itt az előző fejezetek több eredményére is hivatkozunk, amelyekre a karakterizáció bizonyításához már szükségünk volt, pusztán ehhez a részhez viszont valamilyen speciális eset is elég lenne.

A 4. fejezetben ismertetjük Harsanyi (1974) kritikáját a stabil halmazokkal kapcsolatban, valamint az általa javasolt nemkooperatív alkujátékot (illetve annak egy változatát), melynek a egyensúlyi stratégiái, véleménye szerint jobban megfogná a fogalmat, amelyet a stabil halmazokkal próbáltak. A 2. fejezetben található karakterizáció segítségével megmutatjuk, hogy a hozzárendelési játékok esetén ennek a nemkooperatív játéknak az egyensúlyi stratégiaprofiljai pontosan a stabil halmazokat adják meg, így ezen játékosztályon a Harsányi által megfogalmazott probléma a stabil halmazokkal nem áll fenn. Ez a rész szinte teljesen megegyezik a Bednay (2012) cikkel.

Az 5. fejezetben a hozzárendelési játékok egy általánosításával, a többoldalú hozzárendelési játékokkal foglalkozunk. A szükséges definíciók ismertetése után megmutatjuk, hogy Solymosi \& Raghavan (2001)-es a mag stabilitásáról szóló tétele általánosít- 
ható erre a játékosztályra is. Ez az eredmény korábban csak a legkisebb nemtriviális esetben volt ismert Atay \& Núñez (2019). A bizonyításunk azon kívül, hogy sokkal általánosabb, lényegesen rövidebb és egyszerübb is. Az Atay \& Núñez (2019)-féle esetre adunk egy külön bizonyítást is. Bár ez, az általános bizonyításnál, kicsit bonyolultabb, még így is lényegesen egyszerübb mint a régi, viszont megmutatja a játék magjának egy érdekes tulajdonságát, amely a sima hozzárendelési játékok esetén fennáll, többoldalú esetben viszont csak a legkisebb nemtriviális esetben. 


\section{Stabil halmazok és hozzárendelési játékok}

\subsection{Bevezetés}

Klasszikus könyvükben Von Neumann \& Morgenstern (1944) az elosztások egy olyan halmazát tekintették egy kooperatív játék megoldásának (mai terminológiával stabil halmazának), amelyben semelyik két elosztás nem dominálja egymást, ugyanakkor együttesen dominálják a halmazon kívüli összes elosztást. Egyszerre ezt a két stabilitási követelményt tipikusan vagy nagyon sok, ráadásul bonyolult szerkezetű elosztás-halmaz teljesíti, vagy egyetlen egy sem. E negatívumok ellenére a stabil halmazok iránti érdeklődés nem csökken, hiszen az alapelgondolás jól alkalmazható a viselkedési normák modellezésére különféle gazdasági és társadalmi helyzetekben (lásd pl. Ehlers (2007), Greenberg (1990)).

A stabil halmaz(ok) létezése eddig még csak nagyon speciális játéktípusokra bizonyított például a 3- ill. a 4-személyes játékokra(Von Neumann \& Morgenstern, 1944 . Bondareva et al. 1979), a konvex játékok esetében a mag az egyetlen stabil halmaz (Shapley, 1971), NTU esetben az ordinálisan konvex játékokra Peleg (1986) mutatta meg, hogy a mag az egyetlen stabil halmaz). Lucas (1968a) híres 10-személyes példájából viszont tudjuk, hogy bizonyos játékokban egyetlen stabil halmaz sincs. Ráadásul, erre a példára támaszkodva Shapley \& Shubik (1969) megadott egy olyan 10-szereplős, igen természetes piacmodellhez tartozó játékot, amelynek ugyancsak nincs stabil halmaza. Ezért különösen is érdekes, hogy vajon egy speciális, de jellegében alapvető piactípushoz (amelyben a szereplők szigorúan szétválaszthatók eladókra, ill. vevőkre; az áruk oszthatatlanok; a tranzakciók csak bilaterális kapcsolatban történhetnek; az egyedi hasznosságok átruházhatók) tartoz ó játékok, az ún. hozzárendelési játékok rendelkeznek-e mindig stabil halmazzal. Erre a kérdésre már a hozzárendelési játékokat bevezető Shapley \& Shubik (1972) is választ kívánt adni. A hozzárendelési játékok egy speciális esetében az úgynevezett kesztyüjátékokban Shapley (1959) megadott stabil halmazokat, ennek a speciális esetnek egy speciális esetében amikor csak egy vevő van sikerült az összes stabil halmazt megadnia, ám ezeket nem sikerült általánosítaniuk. Az általános esetet később sem sikerült megoldaniuk, Shapley javasolt is egy halmazt Shubik (1984) könyvében, ami „stabilnak tűnt”, de a stabilitást nem sikerült bebizonyítania. Egy speciális esetet vizsgált Solymosi \& Raghavan (2001). Megadták a hozzárendelési játékok egy olyan részosztályát, ahol a mag (a semmilyen elosztás által nem dominált elosztások halmaza) stabil halmaz, következésképpen az egyetlen stabil halmaz. Núñez \& Rafels (2013) belátták, hogy a Shapley által javasolt halmaz (Shubik, $1984)$ stabil. A hozzárendelési játékokhoz hasonló probléma esetén a házaspárosítások- 
nál (Gale \& Shapley, 1962), amely probléma tekinthető a hozzárendelési játékok nem átruházható hasznosságú változatának Ehlers (2007) megadta a stabil halmazoknak egy karakterizációját, Wako (2010) megmutatta, hogy a házaspárosítás problémában mindig létezik stabil halmaz, és ez a halmaz egyértelmü. Az alábbiakban elöször Solymosi (2007) jegyzete alapján összefoglaljuk a szükséges fogalmakat és alaperedményeket.

\subsubsection{Definíció (TU-játék). Egy $(P, v)$ pár TU-játék ha:}

1. $P \neq \emptyset$ véges halmaz a játékosok halmaza

2. $v: 2^{P} \rightarrow \mathbb{R}$ és $v(\varnothing)=0$ koalíciós függvény

Azaz egy TU-játék a következő: van véges sok játékosunk, és egy függvényünk, ami a játékosok minden részhalmazához egy-egy számot rendel, ennyi hasznot képes elérni az adott koalíció, valamilyen átadható értékmérőben kifejezve. Erre általában mint pénz fogunk hivatkozni.

Azt már tudjuk, hogy melyik koalíció mekkora hasznot képes elérni, most nézzük, hogy a koalíció tagjai mennyit kaphatnak ezért. Vizsgáljuk meg az ilyen kifizetések tulajdonságait:

1.1.2. Definíció. Azt mondjuk, hogy a $(P, v)$ játékban az $\boldsymbol{x}=\left(x_{i}\right)_{i \in P} \in \mathbb{R}^{|P|}$ kifizetésvektor

- elérhető az $S$ koalíció számára, ha $\sum_{i \in S} x_{i} \leq v(S)$;

- elfogadható az $S$ koalíció számára, ha $\sum_{i \in S} x_{i} \geq v(S)$;

- elönyösebb az $S$ számára, mint az $\boldsymbol{y}=\left(y_{i}\right)_{i \in P}$ kifizetés-vektor, ha $x_{i}>y_{i}$ minden $i \in S-r e$;

- az S koalíción keresztül dominálja az $\boldsymbol{y}$ kifizetés-vektort, ha az S számára az $\boldsymbol{x}$ elérhetö, és előnyösebb mint az $\boldsymbol{y}$, (jelölés: $\boldsymbol{x} \operatorname{dom}_{S} \boldsymbol{y}$ );

- nem dominált az $S$ koalición keresztül, ha nincs az $S$ számára elérhető olyan $\boldsymbol{z}$ kifizetés-vektor, amelyre $\boldsymbol{z} \operatorname{dom}_{S} \boldsymbol{x}$;

- dominálja az $\boldsymbol{y}=\left(y_{i}\right)_{i \in P}$ kifizetés-vektort, ha létezik egy olyan $S$ koalíció, amelyre $\boldsymbol{x} \operatorname{dom}_{S} \boldsymbol{y},($ jelölés: $\boldsymbol{x} \operatorname{dom} \boldsymbol{y}$ );

- nem dominált, ha egyetlen S koalíción keresztül sem dominált. 
A jelölések egyszerüsítése végett az $\boldsymbol{x}$ vektorban az $S$ koalíció által kapott összkifizetést $x(S)$-sel jelöljük, azaz $x(S)=\sum_{i \in S} x_{i}$.

A vektorok közti dominanciához hasonlóan bevezthetjük a halmazok közti dominanciát is. Azt mondjuk, hogy a kifizetésvektorok egy $\mathcal{X}$ halmaza dominálja az $\mathcal{Y}$ halmazt, ha $\mathcal{Y}$ minden elemét dominálja $\mathcal{X}$ valamelyik eleme, azaz ha $\forall y \in \mathcal{Y} \exists x \in \mathcal{X}: x$ dom $y$. Az $\mathcal{X}$ halmaz által dominált kifizetésvektorokat $D(\mathcal{X})$-szel fogjuk jelölni.

A dominancia relációval kapcsolatban érdemes megjegyezni, hogy egy adott $S$ koalíción keresztüli dominancia tranzitív, mivel ha $\boldsymbol{x} \operatorname{dom}_{S} \boldsymbol{y}$ és $\boldsymbol{y} \operatorname{dom}_{S} \boldsymbol{z}$ teljesül, az azt jelenti, hogy $x_{i}>y_{i}>z_{i}$ fennáll minden $i \in S$-re, így $x_{i}>z_{i}$ teljesül minden $i \in S$-re. Az első dominanciából pedig következik, hogy $x(S) \leq v(S)$, így az $\boldsymbol{x}$ vektor tényleg dominálja $\boldsymbol{z}$-t.

Ha viszont csak a „sima” dominanciát nézzük és nem követeljük meg, hogy ugyanazon a koalíción keresztül történjen, akkor a tranzitivitás nem teljesül.

1. Példa. Legyen $P=\{1,2,3\}$

$v(123)=(12)=10 ; \quad v(13)=6$, a többi koalíció értéke pedig legyen 0 .

Legyen továbbá $\boldsymbol{x}=(3,7,0) ; \boldsymbol{y}=(2,6,2)$ és $\boldsymbol{z}=(0,10,0)$, ekkor könnyen látszik, hogy $\boldsymbol{x} \operatorname{dom}_{\{1,2\}} \boldsymbol{y}$ és $\boldsymbol{y} \operatorname{dom}_{\{1,3\}} \boldsymbol{z}$ teljesül, $\boldsymbol{x}$ viszont nem dominálja $\boldsymbol{z}$-t. Ehhez elég megnéznünk, hogy $\boldsymbol{x}$ vektor egyedül az 1-es játékosnak előnyösebb $\boldsymbol{z}$-nél, az ő értéke viszont 0 , így számára egyedül az $\boldsymbol{x}$ vektor nem elérhető. A későbbiekben a dominanciareláción alapuló stabil halmazoknál pont a tranzitivitás hiánya fog állandó nehézséget jelenteni, ezért is lehetnek fontosak a 2.2.9, és 2.2.10. következmények, valamint a 2.2.11. állítás, amelyekkel egy tranzitivitás-szerü tulajdonságot fogunk belátni.

A dominancia relációval kapcsolatban egy másik fontos megjegyzés, hogy általában nem kell minden koalíciót vizsgálni, elég a hatékony koalíciókat, amelyek értékei nagyobbak, mint bármely partíciójukban szereplő koalíciók értékeinek összege. Ezt fogalmazzuk meg a következő állításban:

1.1.3. Állítás. Legyen $S \subseteq P$ egy nem hatékony koalíció a $(P ; v)$ játékban, azaz létezik $S$-nek egy $S_{1} ; S_{2} ; \ldots ; S_{r}$ particiója (olyan páronként diszjunkt halmazok, amelyek uniója $S)$, amelyre $\sum_{i=1}^{r} v\left(S_{i}\right) \geq v(S)$. Ekkor, ha egy $\boldsymbol{y}$ vektor dominál egy $\boldsymbol{x}$ vektort az $S$ koalíción keresztül, akkor dominálja valamelyik $S_{i}$ koalíción keresztül is.

BIZONYÍTÁs.

Mivel $\boldsymbol{y}$ dominálja $\boldsymbol{x}$-et az $S$ koalíción keresztül, így $S$ minden tagja számára $\boldsymbol{y}$ előnyösebb mint $\boldsymbol{x}$. Ez természetesen igaz $S$ minden részhalmazára, azaz minden $S_{i}$-re is. $\sum_{i=1}^{r} y\left(S_{i}\right)=y(S) \leq v(S) \leq \sum_{i=1}^{r} v\left(S_{i}\right)$ miatt van olyan $i$, amelyre $y\left(S_{i}\right) \leq v\left(S_{i}\right)$. Erre az $S_{i}$ koalícióra $\boldsymbol{y} \operatorname{dom}_{S_{i}} \boldsymbol{x}$. 
Egy társulás létrejöttéhez elengedhetetlen, hogy a benne résztvevők meg tudjanak egyezni az együtt elérhető legnagyobb összhaszon mindegyikük számára elfogadható elosztásában. Az általunk vizsgált játékokban a társadalomnak érdeke a nagykoalíció (az összes játékosból álló koalíció) megalakulása, mert így többet képesek összesen termelni. Éppen ezért a nagykoalíció által elérhető $v(P)$ egységet szeretnénk szétosztani a játékosok között. A nagykoalíció számára elérhető kifizetés-konfigurációkon belül a koalíciók általi elfogadhatóság szempontjából a következő halmazokat szokták vizsgálni.

1.1.4. Definíció. Azt mondjuk, hogy a $(P, v)$ játékban az $\boldsymbol{x}=\left(x_{i}\right)_{i \in P}$ kifizetés-vektor

- szétosztás, ha $\sum_{i \in P} x_{i}=v(P)$, vagyis a $P$ nagykoalíció számára elfogadható és elérhetö;

- félelosztás, ha $\sum_{i \in P} x_{i} \leq v(P)$ és $x_{i} \geq v(\{i\})$ minden $i \in P$-re, azaz olyan, a nagykoalíció számára elérhetö kifizetésvektor, amelyik minden egyszemélyes koalíció (vagyis játékos) számára elfogadható;

- elosztás, ha $\sum_{i \in P} x_{i}=v(P)$ és $x_{i} \geq v(\{i\})$ minden $i \in P$-re, azaz olyan szétosztás, amelyik minden egyszemélyes koalíció (vagyis játékos) számára elfogadható;

- mag-elosztás, ha $\sum_{i \in P} x_{i}=v(P)$ és $\sum_{i \in S} x_{i} \geq v(S)$ minden $S \subseteq P$-re, azaz olyan szétosztás, amelyik minden koalíció számára elfogadható.

Jelölje $\mathcal{I}_{(P, v)}^{*}$ a szétosztások halmazát, $\mathcal{I}_{(P, v)}^{\prime}$ a félelosztások halmazát, $\mathcal{I}_{(P, v)}$ az elosztások halmazát, és $\mathcal{C}_{(P, v)}$ a mag-elosztások halmazát, röviden a $(P, v)$ játék magját. A későbbiekben, ha egyértelmű melyik játékról van szó elhagyjuk a játékra vonatkozó $(P, v)$ részt. $\mathrm{Az} \mathcal{I}^{\prime} \backslash \mathcal{I}$ halmazra szigorú félelosztáshalmazként, a magot meghatározó egyenlőtlenségekre pedig magegyenlőtlenségekként fogunk hivatkozni.

A dolgozat folyamán a könnyebb átláthatóság kedvéért feltesszük, hogy az egyszemélyes koalíciók értéke 0 . Ez nem jelent megszorítást a játékosztályra, mivel bármely $(P, v)$ játékhoz definiálhatunk egy $\left(P, v_{0}\right)$ játékot, a $v$ játék 0-normalizáltját a következőképpen: $v_{0}(S)=v_{S}-\sum_{i \in S} v(S)$. Ebben a játékban minden egyszemélyes koalíció kifizetése 0, és ha a kifizetésvektorokat is transzformáljuk a játékhoz hasonlóan azaz minden $\boldsymbol{x}$ vektorhoz hozzárendelünk egy $\boldsymbol{x}^{0}$ vektort, amelyre $x_{i}^{0}=x_{i}-v(\{i\})$, könnyen látszik, hogy az $\boldsymbol{x}$ vektor pontosan akkor elosztás, szétosztás, stb a $v$ játékban, ha $\boldsymbol{x}^{0}$ az a $v_{0}$ játékban, továbbá $\boldsymbol{x}$ pontosan akkor dominálja $\boldsymbol{y}$-t a $v$ játékban valamely koalíción keresztül, ha $\boldsymbol{x}^{0}$ dominálja $\boldsymbol{y}^{0}$-t a $v_{0}$ játékban ugyanazon a koalíción keresztül. Ennek az előnye, hogy ha ilyen játékokkal foglalkozunk, akkor a minden játékos számára való elfogadhatóság egyszerüen a nemnegativitással ekvivalens. 
Szétosztás minden játékban van. Félelosztás és elosztás viszont akkor és csak akkor, ha $v(P) \geq \sum_{i \in P} v(\{i\})$, ami egy igen gyenge feltevés a szétosztható $v(P)$ nagyságára vonatkozóan. Mag-elosztások létezéséhez viszont már egy ennél jóval szigorúbb feltételnek kell teljesülnie. Az általunk vizsgált hozzárendelési játékokban ez a feltétel mindig teljesül, a mag tehát sosem üres (Shapley, Shubik, 1972). A mag-elosztások pedig jellemezhetők úgy, mint azok a szétosztások, amiket semmilyen szétosztás nem dominál. A mag ezen definíciójának mintájára definiálhatjuk bármilyen $\mathcal{X} \subseteq \mathbb{R}^{P}$ halmaz magját, mint a halmaznak az a része, amit semelyik $\mathcal{X}$-beli vektor nem dominál:

\subsubsection{Definíció ( $\mathcal{X} \subseteq \mathbb{R}^{P}$ halmaz magja).}

$$
\mathcal{C}_{(P, v)}(\mathcal{X})=\{\boldsymbol{x} \in \mathcal{X} \mid \nexists \boldsymbol{y} \in \mathcal{X}: \boldsymbol{y} \operatorname{dom} \boldsymbol{x}\}
$$

Ha egyértelmű, melyik játékról van szó, akkor a játékot jelölő $(P, v)$ párt a maghoz hasonlóan itt is el fogjuk hagyni.

Von Neumann \& Morgenstern (1944) alapvetően olyan játékokat vizsgáltak, amelyekben nincsen mag-elosztás, ezért ők az elosztások egyenkénti nem domináltsága helyett egy ennél gyengébb stabilitás fogalmat vezettek be.

1.1.6. Definíció (Stabil halmaz). Egy $\mathcal{V} \subseteq \mathcal{I}$ halmaz stabil, ha teljesíti a következő két tulajdonságot:

- Belső stabilitás: $\nexists \boldsymbol{x}, \boldsymbol{y} \in \mathcal{V}: \boldsymbol{x}$ dom $\boldsymbol{y}$

- Külső stabilitás: $\forall \boldsymbol{y} \in \mathcal{I} \backslash \mathcal{V} \quad \exists \boldsymbol{x} \in \mathcal{V}: \boldsymbol{x}$ dom $\boldsymbol{y}$

Más jelölésekkel a belső stabilitás azt jelenti, hogy $\mathcal{V}$ halmaz megoldása a $\mathcal{X} \cap D(\mathcal{X})=\varnothing$ egyenletnek, a külső stabilitás pedig azt, hogy megoldása az $D(\mathcal{X}) \supseteq \mathcal{I} \backslash \mathcal{X}$ tartalmazásnak. A kettő együtt, azaz a $\mathcal{V}$ halmaz stabilitása pedig úgy fogalmazható meg, hogy $\mathcal{V}$ megoldása a $\mathcal{X}=\mathcal{I} \backslash D(\mathcal{X})$ egyenletnek.

Fontos megjegyezni, hogy míg egy kifizetésvektorról el lehet dönteni, hogy elosztásvektore, vagy mag-elosztás-e, addig a stabil halmazra ugyanezt nem tudjuk megtenni. Az hogy egy vektor benne van-e egy stabil halmazban nem csak attól az egy vektortól függ, hanem az összes többitől is.

Von Neumann \& Morgenstern (1944) szerint egy stabil halmaz tekinthető egyfajta normának, amelyben a társadalom által jónak tekintett kifizetések vannak. A belső stabilitás ebben az esetben azt jelenti, hogy egyik ilyen igazságos elosztás esetén sem tud fellépni egy koalíció sem, és kiharcolni egy másikat. A külső stabilitás pedig azt jelenti, hogy ha van egy rossz (nem a stabil halmazbeli) elosztásunk, akkor annak a vektornak a rosszaságát le tudjuk vezetni, egy jó vektorból, amely dominálja. 
A teljes elosztáshalmaz nyilván mindig teljesíti a külső stabilitást, de csak igen elfajult esetben lesz belsőleg is stabil. Egy egyelemü elosztáshalmaz viszont belsőleg mindig stabil, de csak nagyon elfajult játékban lesz külsőleg is stabil. Alapvető tehát a kérdés, hogy egy adott játéktípusban létezik-e mindig stabil halmaz. Lucas (1971), Lucas (1992) áttekintő tanulmányai szerint nem túl bőséges a pozitív eredmények köre. Megemlítünk néhányat:

- Von Neumann \& Morgenstern (1944) bizonyította, hogy minden 3-személyes játék rendelkezik legalább egy stabil halmazzal, sőt teljesen leírták a stabil halmazok jellegét is;

- Bondareva et al. (1979) megmutatták, hogy minden 4-személyes játék rendelkezik legalább egy stabil halmazzal, az összes stabil halmaz jellemzése viszont nem ismert;

- Lucas (1968a) mutatott egy 10-személyes játékot, amelynek egyetlen stabil halmaza sincs. .

A mag, mint a semmilyen szétosztás által nem dominált elosztások halmaza, nyilván mindig teljesíti a belső stabilitást. Kérdés, hogy mikor stabil külsőleg is. Könnyen beláthatók az alábbi észrevételek:

\subsection{7. Állítás. Bármely TU-játékban}

1. minden stabil halmaz zárt;

2. a mag (akár üres akár nem) részhalmaza bármelyik stabil halmaznak;

3. egyetlen stabil halmaz sem valódi része egy másik stabil halmaznak;

4. az elözőekből következően, ha egy játékban a mag egy stabil halmaz, akkor a mag az egyetlen stabil halmaz.

Elég természetesen adná magát a második és a negyedik pont megfordítása, azaz hogy egy játékban az összes stabil halmaz metszete a játék magja, illetve, hogy ha csak egy stabil halmaz van, akkor az a játék magja. Lucas (1968b) megmutatta, hogy ez nem igaz. Megadott egy 5 személyes játékot, amelynek egyetlen stabil halmaza van, amely szigorúan tartalmazza a magot, ráadásul a maggal ellentétben nem is konvex. Ugyanebben a cikkben a stabil halmazok egy másik furcsa tulajdonságára is hoz egy példát. Megad egy 8 személyes játékot, amelyben hiába vannak szimmetrikus játékosok, szimmetrikus stabil halmaza viszont nincsen. 
Azt, hogy általában a fenti felsorolásnál „sokkal szebb” eredményeket nem kaphatunk a stabil halmazok szerkezetével kapcsolatban jól mutatja Shapley (1959) eredménye. Tetszőleges $n$ dimenziós korlátos és zárt halmazhoz (még az összefüggőséget sem követeljük meg) megadható egy $n+3$ személyes játék, amelyben stabil az általunk megadott halmaz és egy másik ettől diszjunkt zárt halmaz uniója. Azaz akármilyen korlátos és zárt halmazt adunk meg, található egy játék, amelynek valamely stabil halmazában az általunk megadott halmazt viszont fogjuk látni. Nash (1958) megjegyzi, ez azt jelenti, hogy az aláírásunk (feltéve természetesen, hogy korlátos és zárt) része egy 5 személyes játék stabil halmazának.

Az általunk vizsgált játékosztályon viszont mint később látni fogjuk sokkal jobb a helyzet, a fenti furcsaságok ott nem fordulhatnak elő.

A maghoz hasonlóan a stabil halmaz fogalmát is általánosíthatjuk:

1.1.8. Definíció. Legyen $\mathcal{X} \subseteq \mathbb{R}^{P}$. Egy $\mathcal{V} \subseteq \mathcal{X}$ halmaz stabil az $\mathcal{X}$ halmazra nézve, röviden $\mathcal{X}$-stabil, ha teljesíti a következő két tulajdonságot:

- Belső stabilitás: $\nexists \boldsymbol{x} ; \boldsymbol{y} \in \mathcal{V}: \boldsymbol{x} \operatorname{dom} \boldsymbol{y}$

- Külső stabilitás: $\forall \boldsymbol{y} \in \mathcal{X} \backslash \mathcal{V} \exists \boldsymbol{x} \in \mathcal{V}: \boldsymbol{x} \operatorname{dom} \boldsymbol{y}$

Az ilyen általánosított stabil halmazokra is kimondhatóak hasonló tulajdonságok, mint a „rendes” stabil halmazokra:

1. minden $\mathcal{X}$-stabil halmaz zárt $\mathcal{X}$-re nézve;

2. $\mathcal{X}$ halmaz magja részhalmaza bármelyik $\mathcal{X}$-stabil halmaznak;

3. egyetlen $\mathcal{X}$-stabil halmaz sem valódi része egy másik $\mathcal{X}$-stabil halmaznak;

4. az előzőekből következően, ha egy játékban $\mathcal{C}(\mathcal{X})$ egy $\mathcal{X}$-stabil halmaz, akkor ez az egyetlen $\mathcal{X}$-stabil halmaz.

A későbbiekben sokszor kényelmesebb lesz a félelosztáshalmazzal dolgozni mint az elosztáshalmazzal, ezért nagyon hasznos lesz a következő állítás:

1.1.9. Állítás. Egy halmaz pontosan akkor stabil (az elosztáshalmazra nézve stabil), ha a félelosztáshalmazra nézve stabil.

BiZONYÍTÁS.

Mindkét irányt meg kell vizsgálnunk. 
- Minden $\mathcal{V}$ stabil halmaz $\mathcal{I}^{\prime}$-stabil: a belső stabilitás nyilvánvaló, mert az nem függ az alaphalmaztól. $\mathcal{V}$ stabilitása miatt tudjuk, hogy dominálja az $\mathcal{I} \backslash \mathcal{V}$ halmazt. Az I'-stabilitáshoz meg kell mutatnunk, hogy az összes szigorú félelosztást (azaz az $\mathcal{I}^{\prime} \backslash \mathcal{I}$ halmazt) is dominálja.

Vegyünk egy $\boldsymbol{x}$ egy szigorú félelosztást, és növeljük meg $\boldsymbol{x}$ minden koordinátáját $\frac{v(P)-x(P)}{|P|}$-vel. Ekkor egy $\boldsymbol{y}$ elosztást kapunk. Könnyen látható, hogy $\boldsymbol{y}$ elosztás dominálja $\boldsymbol{x}$-et a nagykoalíción keresztül. ha $\boldsymbol{y} \in \mathcal{V}$, akkor találtunk egy elemét $\mathcal{V}$ nek, ami dominálja $\boldsymbol{x}$-et. Ha $\boldsymbol{y} \notin \mathcal{V}$, akkor $\mathcal{V}$ stabilitása miatt $\exists \boldsymbol{z} \in \mathcal{V}: \boldsymbol{z}$ dom $\boldsymbol{y}$, de mivel $\boldsymbol{y}>\boldsymbol{x}$, így $\boldsymbol{z}$ dominálja $\boldsymbol{x}$-et is ugyanazon a koalíción keresztül, tehát találtunk egy $\mathcal{V}$ beli vektort, amely dominálja $\boldsymbol{x}$-et.

- Minden $\mathcal{V}$ halmaz, amely $\mathcal{I}^{\prime}$-stabil az stabil is egyben: ebben az esetben nyilvánvaló, hogy $\mathcal{V}$ dominálja az $\mathcal{I} \backslash \mathcal{V}$ halmazt, azt viszont meg kell mutatni, hogy $\mathcal{V} \subseteq \mathcal{I}$. Tegyük fel, hogy létezik $\boldsymbol{x} \in \mathcal{V} \cap\left(\mathcal{I}^{\prime} \backslash \mathcal{I}\right)$. Az előző ponthoz hasonlóan növeljük meg $\boldsymbol{x}$ minden koordinátáját, hogy egy $\boldsymbol{y}$ elosztást kapjunk. Mivel $\boldsymbol{y} \operatorname{dom}_{P} \boldsymbol{x}$, így $\boldsymbol{y}$ nem lehet eleme $\mathcal{V}$-nek a belső stabilitás miatt. Ekkor viszont létezik egy $\boldsymbol{z} \in \mathcal{V}$ vektor, ami dominálja $\boldsymbol{y}$-t és így $\boldsymbol{x}$-et is, ami ellentmond $\mathcal{V}$ belső stabilitásának.

A stabil halmazokat egy speciális játékosztályon, a hozzárendelési játékok osztályán fogjuk vizsgálni.

1.1.10. Definíció (Hozzárendelési játék). Egy $(P ; v)$ játékra akkor mondjuk, hogy hozzárendelési játék, ha a játékosok halmazának van egy $P=M \cup N, M \cap N=\varnothing$ partíciója és található hozzá olyan nemnegatív $A=\left[a_{i j}\right]_{i \in M ; j \in N}$ mátrix, amelyre minden $S \subseteq P$ koalíció esetén

$$
v(S)=v_{A}(S):=\max _{\mu \in \Pi(S \cap M ; S \cap N)} \sum_{(i ; j) \in \mu} a_{i j}
$$

Ahol $\Pi(X ; Y)$ az $X$ és $Y$ halmazok közti párositások (egy $X^{\prime} \subseteq X$ és egy $Y^{\prime} \subseteq Y$ halmaz közti bijekciók) halmaza.

Egy hozzárendelési játékot a következőképpen tudunk elképzelni: sorokhoz tartoznak az eladók, az oszlopokhoz a vevők. Minden vevő egy dolgot akar venni, és minden eladó egyet akar eladni. Az $a_{i j}$ mátrixelem az a szám, amennyivel többre értékeli a $j$-edik vevő az $i$-edik eladó áruját mint az eladó, azaz amennyi a társadalom összhaszna ha megvalósul az üzlet kettejük közt. Egy koalíció értéke annyi, amennyi társadalmi összhasznot ők egymás közt üzletelve maximálisan el tudnak érni. Feltehető, hogy az $A$ 
mátrix nemnegatív, mert minden koalíció értékénél csak a maximális súlyú párosítások értéke számít, de azokban negatív értékek úgysem szerepelhetnek. A továbbiakban a jelölés egyszerüsítése végett hozzárendelési játékoknál a szétosztás-, félelosztás- és elosztáshalmaznál valamint a magnál a játékot jelölő $(P ; v)$ játékos, koalíciós függvény pár helyett csak az $A$ mátrixot fogjuk kiírni, ami meghatározza a játékot, ha egyértelmü, melyik játékról van szó, akkor azt is elhagyjuk. Feltesszük továbbá, hogy a mátrix négyzetes, mivel ha nem az, akkor megfelelő számú 0-s sor vagy oszlop hozzávételével ez elérhető. Valamint feltesszük, hogy a fóátlóban egy maximális súlyú párosítás található, mivel a sorok és oszlopok átrendezésével ez mindig elérhető.

A hozzárendelési játékok egyik speciális tulajdonsága, hogy csak az egyszemélyes illetve a vegyes kétszemélyes (egy eladóból és egy vevőből álló) koalíciók a hatékonyak. Ebből következik, hogy ha egy (fél)elosztás dominál egy másikat, akkor dominálja egy vegyes kétszemélyes koalíción keresztül is. A kifizetésvektorokban ezért különválasztjuk az eladók és a vevők kifizetését például az $(\boldsymbol{u} ; \boldsymbol{v})$ vektorban $\boldsymbol{u}$ az eladók-, $\boldsymbol{v}$ a vevők kifizetéseit tartalmazó vektor lesz. Az $i$. eladó és $j$. vevő alkotta koalíción keresztüli dominanciát pedig dom $_{i j}$-vel jelöljük. Érdemes megjegyezni, hogy a stabil halmazokra vonatkozó későbbi eredmények nem csak a hozzárendelési játékokra igazak, hanem minden olyan játékra, amelyben csak az egyszemélyes és a vegyes kétszemélyes koalíciók hatékonyak. Az ilyen játékokat úgy kaphatjuk meg, hogy veszünk egy hozzárendelési játékot, majd az egy- és vegyes kétszemélyes koalíciókon kívül a többit szabadon lecsökkenthetjük. Az egyetlen kivétel ez alól némely esetben a nagykoalíció értéke, mivel ha azt megváltoztatjuk, akkor megváltozik az elosztáshalmaz is. Ha lecsökkentjük a nagykoalíció értékét, akkor például a mag egyből üres lesz.

A hozzárendelési játékok egyik legfontosabb tulajdonságát mutatja a következő tétel:

1.1.11. Tétel (Shapley, Shubik, 1972). Legyen A egy tetszóleges nemnegatív mátrix. Ekkor

1. az A mátrixhoz tartozó hozzárendelési játék magja nemüres;

2. bármely hozzárendelési játék magja háló, azaz $\left(\boldsymbol{u}^{1} ; \boldsymbol{v}^{1}\right),\left(\boldsymbol{u}^{2} ; \boldsymbol{v}^{2}\right) \in \mathcal{C}$ esetén $\left(\boldsymbol{u}^{1} \vee\right.$ $\left.\boldsymbol{u}^{2} ; \boldsymbol{v}^{1} \wedge \boldsymbol{v}^{2}\right),\left(\boldsymbol{u}^{1} \wedge \boldsymbol{u}^{2} ; \boldsymbol{v}^{1} \vee \boldsymbol{v}^{2}\right) \in \mathcal{C}$, ahol $\vee$ a koordinátánkénti maximumot, $\wedge a$ koordinátánkénti minimumot jelöli. Az ily módon konstruált vektorokat a későbbiekben az $\left(\boldsymbol{u}^{1} ; \boldsymbol{v}^{1}\right)$ és $\left(\boldsymbol{u}^{2} ; \boldsymbol{v}^{2}\right)$ vektorok hálókombinációjának fogjuk nevezni.

3. Az elözö pontból következöen van két olyan mag-elosztás, amely a játékosok magbeli extrém kifizetéseiböl áll: az egyikben minden eladó a minimumot és minden vevő a maximumot kapja, a másik speciális mag-elosztásban pedig fordítva, azaz 


$$
\begin{aligned}
& \exists(\overline{\boldsymbol{u}} ; \underline{\boldsymbol{v}}) \in \mathcal{C}: \bar{u}_{i}=\max \left\{u_{i}:(\boldsymbol{u} ; \boldsymbol{v}) \in \mathcal{C}\right\} \quad ́ s \underline{v}_{j}=\min \left\{v_{j}:(\boldsymbol{u} ; \boldsymbol{v}) \in \mathcal{C}\right\} \text { illetve } \\
& \exists(\underline{\boldsymbol{u}} ; \overline{\boldsymbol{v}}) \in \mathcal{C}: \underline{u}_{i}=\min \left\{u_{i}:(\boldsymbol{u} ; \boldsymbol{v}) \in \mathcal{C}\right\} \text { és } \bar{v}_{j}=\max \left\{v_{j}:(\boldsymbol{u} ; \boldsymbol{v}) \in \mathcal{C}\right\}
\end{aligned}
$$

Az utolsó pontot érdemes lehet egy kicsit jobban megnézni. A háló csak annyit tud, hogy két elem hálókombinációja szintén a hálóban van, ezt többször felhasználva természetesen el tudjuk érni, hogy ha véges sok vektort veszünk a hálóból, akkor ennek a véges sok vektornak az extrém kifizetéseit, ahol minden eladó a minimumot, vevő a maximumot kapja, szintén tartalmazza a háló. A magnak azonban jellemzően végtelen sok eleme van, végtelen sok elemet azonban nem tudunk „hálókombinálni”. Erre viszont nincs is szükségünk, mivel tudjuk, hogy a mag korlátos és zárt, így minden egyes koordinátához találhatunk egy magelemet, amelyben az adott koordináta minimális/maximális, és elég ezt a véges sok vektort kombinálnunk.

Hozzárendelési játékok esetén könnyen látszik, ha veszünk egy maximális értékü párosítást és egy tetszőleges elemét a magnak, akkor minden vegyespáros, amelyik szerepel a párosításban pontosan annyit kap, amennyi az értékük. Ez azért van, mert ha összeadjuk egy maximális értékü párosításhoz tartozó magegyenlőtlenségeket, az összeg egyenlőségre fog teljesülni. Mivel a mag része a szétosztáshalmaznak, ez azt jelenti, hogy minden egyes összeadott egyenlőtlenség is egyenlőségre teljesül. A későbbiekben fontos lesz nekünk ez a részhalmaz, ahol egy maximális párosításban szereplö párok pontosan az értéküket kapják. Ezt a halmazt adja meg a következő definíció:

1.1.12. Definíció (Principal section). Egy az A mátrix által meghatározott hozzárendelési játékban a $\mu$ maximális súlyú párosításhoz tartozó principal section a következő halmaz:

$$
\mathcal{B}_{A, \mu}=\left\{(\boldsymbol{u} ; \boldsymbol{v}) \in \mathcal{I}_{A} \mid \forall i \in M: u_{i}+v_{\mu(i)}=a_{i \mu(i)}\right\}
$$

Azaz az elosztáshalmaznak az a része, amelyben a $\mu$ maximális súlyú párositásban szereplö párosok pontosan annyit kapnak amennyi az értékük.

A későbbiekben ha egyértelmü, hogy melyik játékról, illetve párosításról van szó akkor az $A, \mu$ részt el fogjuk hagyni.

A principal section általában csak egy nagyon kis része az elosztáshalmaznak. Míg az elosztáshalmaz egy $|P|-1$ dimenziós szimplex addig a principal section csak egy körülbelül feleannyi dimenziós téglatest. A principal section nagy előnye az lesz, hogy az elosztáshalmazzal ellentétben zárt a hálókombináció képzésére. 


\subsection{A mag stabilitása}

Ebben a részben azt fogjuk megvizsgálni, hogy mikor stabil egy hozzárendelési játék magja. Adunk egy másik bizonyítást Solymosi \& Raghavan (2001) következő tételére. A bizonyítás megtalálható már Bednay (2009) szakdolgozatban is, később függetlenül ugyanezt a bizonyítást felfedezte Atay (2017) is.

1.2.1. Tétel. [Solymosi, Raghavan, 2001] Egy hozzárendelési játékban a mag pontosan akkor stabil, ha a generáló mátrix fóátlódomináns, azaz a maximális párositás minden eleme sor-, és oszlopmaximum is egyben.

Jelöljük a mátrix főátlójából (ahol feltevésünk szerint egy maximális súlyú párosítás található) készített vektort $\boldsymbol{d}$-vel, a csupa 0-ból álló vektort pedig $\mathbf{0}$-val. Nyilvánvaló, hogy a fóátlódominancia ekvivalens azzal, hogy a mag tartalmazza a $(\mathbf{0} ; \boldsymbol{d})$ és $(\boldsymbol{d} ; \mathbf{0})$ elemeket. A mag nem dominálja ezt a két elosztást, mivel minden $(\boldsymbol{u} ; \boldsymbol{v})$ magelem nemnegatív, továbbá minden $i$-re igaz, hogy $u_{i}+v_{i}=a_{i i}$, így sem az $i$. eladó, sem az $i$. vevő nem kaphat $a_{i i}=d_{i}$-nél többet. Ezzel beláttuk, hogy a mag stabilitásának szükséges feltétele, hogy a mátrix főátlódomináns legyen. A nehezebb kérdés az elégségesség.

A dolgozat későbbi részében adunk két másik bizonyítást is a tételre. A 2.1.2, tételnek lesz egy egyszerü következménye 2.2.1. állítás), valamint az 5.2.3. tétel speciális esete. Annak, hogy miért látjuk be mégis külön, több oka is van. Egyrészt ez a bizonyítás sokkal egyszerúbb, mint a 2.1.2. tételé, másrészt az 5.2.3. tétel bizonyításánál kicsit többet is megmutat: ebből a bizonyításból látszik a hozzárendelési játék magjának egy speciális tulajdonsága, aminek segítségével minden magon kívüli elemhez meg tudjuk mondani az összes vegyespárost, amin keresztül dominálja a mag. Ez a tulajdonság a többoldalú hozzárendelési játékok esetében csak a legkisebb nemtriviális, a $2+2+2$-es játékoknál teljesül 5.3.1. Állítás).

A dominancia reláció bevezetése után az 1.1.3. állításban láttuk, hogy ha két vektor közti dominanciát vizsgáljuk nem minden koalíció érdekes csak a hatékonyak. Ha a mag stabilitását vizsgáljuk, akkor tovább szúkíthető az „érdekes” koalíciók halmaza. Ha van egy nem magbeli elem, akkor azt egy magelem csak olyan koalíción keresztül dominálhatja, amelyhez tartozó magegyenlőtlenséget egyenlőségre teljesíti. A következő lemmában azt mutatjuk meg, hogy minden nem magbeli elemhez található ilyen koalíció. Ezt az állítást a hozzárendelési játékoknál bővebb játékosztályra látjuk be.

1.2.2. Lemma. Legyen $(P ; v)$ egy nemnegatív kooperatív játék, amelynek nemüres a magja. Ekkor minden nem magbeli elosztás megszeg egy olyan magegyenlötlenséget, amely valamelyik magelemre egyenlőségként teljesül. 


\section{BIZONYÍTÁs.}

Az állitást a koalíciós függvény értékei között szereplő nem 0 értékek száma szerinti teljes indukcióval bizonyítjuk. Ha minden koalíció értéke 0, akkor a mag és az elosztáshalmaz is ugyanabból az egy elemből áll, amiben minden játékos kifizetése 0 , így az $\mathcal{I} \backslash \mathcal{C}$ halmaz üres, tehát az állítás igaz.

Tegyük fel, hogy az olyan játékokra igaz az állítás, amelyekben legfeljebb $k$ darab koalíció értéke nem 0 . Vegyünk egy olyan játékot, amelyben éppen $k+1$ darab koalíció értéke nem 0. Tudjuk, hogy a nem magbeli $\boldsymbol{x}$ elosztás megszeg egy $S$ koalícióhoz tartozó magegyenlőtlenséget (ezért nem magbeli). $0 \leq x(S)<v(S)$ miatt az $S$ koalíció értéke pozitív. Ha a magnak van olyan eleme, amelyre ez az egyenlőtlenség egyenlöségként teljesül, akkor készen is vagyunk. Ha nincs, akkor az egyenlőtlenség nem határolja a magot, így ha lecsökkentjük $v(S)$ értékét 0-ra, akkor az így kapott egyenlőtlenségek által meghatározott halmaz nem változik. Jelöljük $w$-vel a $v$ játékból a $v(S)$ érték lenullázásával kapott játékot. Ezzel a jelöléssel a fent leírtak azt jelentik, hogy $\mathcal{C}_{(P ; v)}=$ $\mathcal{C}_{(P ; w)}$. $w$-ben viszont eggyel kevesebb koalíció értéke nem 0 , így az indukciós feltevés miatt a $w$ játék magjában (ami ugyanaz mint a $v$ játék magja) van olyan elem és koalíció, amely koalícióhoz tartozó egyenlőtlenséget az $\boldsymbol{x}$ megszegi, a magbeli elemre pedig az ezen koalícióhoz tartozó egyenlőtlenség egyenlőségként teljesül. Ekkor viszont nyilván ugyanez igaz a $v$ játékban is, amivel beláttuk az állítást.

A mag stabilitásának megmutatásához szükségünk lesz az alábbi definícióra:

1.2.3. Definíció. $(\boldsymbol{u} ; \boldsymbol{v}) \in \mathcal{C}_{A}, \tau \in \mathbb{R}$ ekkor legyen $\left(\boldsymbol{u}^{(\tau)} ; \boldsymbol{v}^{(\tau)}\right)=\left(\operatorname{med}\left(0, u_{1}+\tau, a_{11}\right) \ldots\left(\operatorname{med}\left(0, u_{n}+\tau, a_{n n}\right) ;\right.\right.$ $\left.\operatorname{med}\left(0, v_{1}-\tau, a_{11}\right) \ldots \operatorname{med}\left(0, v_{n}-\tau, a_{n n}\right)\right)$, ahol $\operatorname{med}(x, y, z)$ az $x, y$ és $z$ értékek mediánját jelöli.

Ez azt jelenti, hogy ha van egy $(\boldsymbol{u} ; \boldsymbol{v})$ magelemünk, akkor minden eladó kifizetését megnöveljük és minden eladó kifizetését lecsökkentjük $\tau$-val, kivéve ha ezzel egy $(i ; i)$ páros egyik tagjának a kifizetése negatívvá válna (ekkor a másiké nagyobb lenne mint $a_{i i}$, ekkor ezt a párost csak eddig a határig változtatjuk.

1.2.4. Lemma. Ha A föátlódomináns és $(\boldsymbol{u} ; \boldsymbol{v}) \in \mathcal{C}_{A}$, akkor $\left(\boldsymbol{u}^{(\tau)} ; \boldsymbol{v}^{(\tau)}\right) \in \mathcal{C}_{A} \quad \forall \tau \in \mathbb{R}$ esetén.

BIZONYÍTÁs.

Tegyük fel, hogy nem igaz a lemma, ekkor $\exists \tau, i, j: u_{i}^{(\tau)}+v_{j}^{(\tau)}<a_{i j}$. Mivel $(\boldsymbol{u}, \boldsymbol{v})$ eleme a magnak, így $u_{i}+v_{j} \geq a_{i j}$. A fenti egyenlőtlenség tehát csak akkor teljesülhet, ha $u_{i}^{(\tau)}+v_{j}^{(\tau)}<u_{i}+v_{j}$. Ez $\left(\boldsymbol{u}^{(\tau)}, \boldsymbol{v}^{(\tau)}\right)$ definíciója miatt csak akkor teljesülhet, ha 
$u_{i}^{(\tau)}=a_{i i} \operatorname{vagy} v_{j}^{(\tau)}=a_{j j}$. Ebben az esetben viszont a főátlódominancia miatt már ez az egy koordináta is legalább akkora mint $a_{i j}$, ami ellentmond a feltevésünknek.

Most már be tudjuk látni az 1.2.1. tételt.

BIZONÍYÍTÁS 1.2.1. TÉTEL).

A belső stabilitás triviális a mag definíciója miatt: a magban azok az elosztások vannak, amelyeket nem dominál semmilyen szétosztás, speciálisan semmilyen mag-elosztás sem. Külső stabilitás: Azt kell belátni, hogy minden $(\boldsymbol{u} ; \boldsymbol{v}) \in \mathcal{I} \backslash \mathcal{C}$ elosztást dominál egy magbeli. az 1.2.2. Lemma miatt $\exists(i, j), \quad\left(\boldsymbol{u}^{\prime} ; \boldsymbol{v}^{\prime}\right) \in \mathcal{C}: u_{i}+v_{j}<a_{i j}=u_{i}^{\prime}+v_{j}^{\prime}$ Ekkor $\tau=\frac{u_{i}+a_{i j}-v_{j}}{2}-u_{i}^{\prime}$-re $\left(\boldsymbol{u}^{\prime(\tau)} ; \boldsymbol{v}^{\prime(\tau)}\right) \operatorname{dom}_{(i, j)}(\boldsymbol{u} ; \boldsymbol{v})$

az 1.2.4. Lemma miatt $\left(\boldsymbol{u}^{\prime(\tau)} ; \boldsymbol{v}^{\prime(\tau)}\right) \in \mathcal{C}$, ami azt jelenti, hogy találtunk egy magbeli elosztást, ami dominálja $(\boldsymbol{u} ; \boldsymbol{v})$-t.

A következő példákon keresztül megmutatjuk, hogy geometriailag mit jelent a játék magja, és a dominancia. Két eladó és két vevő van a táblázatban szereplő 4 szám a hozzárendelési játékot megadó mátrix. Az eladók (akikhez a sorok tartoznak kifizetésit $u_{1}$-gyel illetve $u_{2}$-vel, a vevők (akikhez az oszlopok tartoznak) kifizetéseit $v_{1}$-gyel illtve $v_{2}$-vel jelöljük. A könnyebb átláthatóságért, hogy melyik játékos kifizetését mivel jelöljük a mátrixtól balra, illetve fölötte ki is írjuk. A későbbi példákban is ilyen módon fogjuk megadni a játékokat.

2. Példa. \begin{tabular}{c|cc|} 
& $v_{1}$ & $v_{2}$ \\
\hline$u_{1}$ & 7 & 3 \\
$u_{2}$ & 2 & 4 \\
\hline
\end{tabular}

Itt a nagykoalíció értéke 11. Az elosztáshalmaz az 1. ábrán látható tetraéder, amelynek a csúcsai azok a vektorok, amelyekben egy játékos kifizetése 11, a többié 0 . Formálisan $\mathcal{I}=\left\{\left(u_{1}, u_{2} ; v_{1}, v_{2}\right) \in \mathbb{R}_{+}^{4}: u_{1}+u_{2}+v_{1}+v_{2}=11\right\}$. Innentől $\mathbb{R}_{+}$-szal fogjuk jelölni a nemnegatív valós számok halmazát. A principal section a színes síkmetszet, ahol az első vevő-első eladó páros 7 egységen, míg a másik két játékos a maradék 4-en osztozik. $\mathcal{B}=\left\{\left(u_{1}, u_{2} ; v_{1}, v_{2}\right) \in \mathbb{R}_{+}^{4}: u_{1}+v_{1}=7, \quad u_{2}+v_{2}=4\right\}$. A két szaggatott sík adja meg azokat a pontokat, amelyekre a másik két (a nem fóátlóban lévő elemekhez tartozó) magegyenlőtlenség egyenlőségre teljesül. A játék magja a principal sectionnek ezen két sík közti része, a zöld levágott sarkú téglalap. $\mathcal{C}=\left\{\left(u_{1}, u_{2} ; v_{1}, v_{2}\right) \in \mathcal{B}\right.$ : $\left.u_{1}+v_{2} \geq 3, \quad u_{2}+v_{1} \geq 2\right\}$.

A principal sectiont a 2 , ábrán külön is ábrázoltuk. A vízszintes tengelyen balról jobbra található az első vevő kifizetése $\left(u_{1}\right)$, mivel az első vevő és első eladó a principal sectionben összesen 7-et kap, így az első eladó kifizetése is a vízszintes tengelyen található, csak az jobbról balra nő. Hasonlóan a függőleges tengelyen alulról felfelé 
található a második eladó kifizetése, míg fölülről lefelé a második vevoó. A magnak a $45^{\circ}$-os oldalai ahol az $(1 ; 2)$-es illetve $(2 ; 1)$-es vegyespároshoz tartozó magegyenlőtlenségek aktívak dominálják a két piros háromszöget ezen két koalíción keresztül. Egy-egy pontra be is jelöltük, hogy milyen irányba képesek dominálni. A bal felső oldal minden pontja dominálja a tőle szigorúan balra felfelé levő pontokat, míg a jobb alsó oldal a tőle szigorúan jobbra lefelé lévőket. az 1.2.4. lemma tartalma is könnyen látszik ezen a példán, ha kivesszük egy tetszőleges pontját a magnak és elindulunk az egy meredekségü egyenes mentén, amennyiben „falba ütköznénk”, azt a koordinátát nem növeljük, hanem haladunk tovább a principal section szélén,egész addig, amíg el nem érjük a bal alsó illetve jobb felső csúcsot, akkor közben végig a magban maradtunk.

1. ábra. $2+2$ játékos stabil mag, elosztáshalmaz

$(11,0 ; 0,0)$

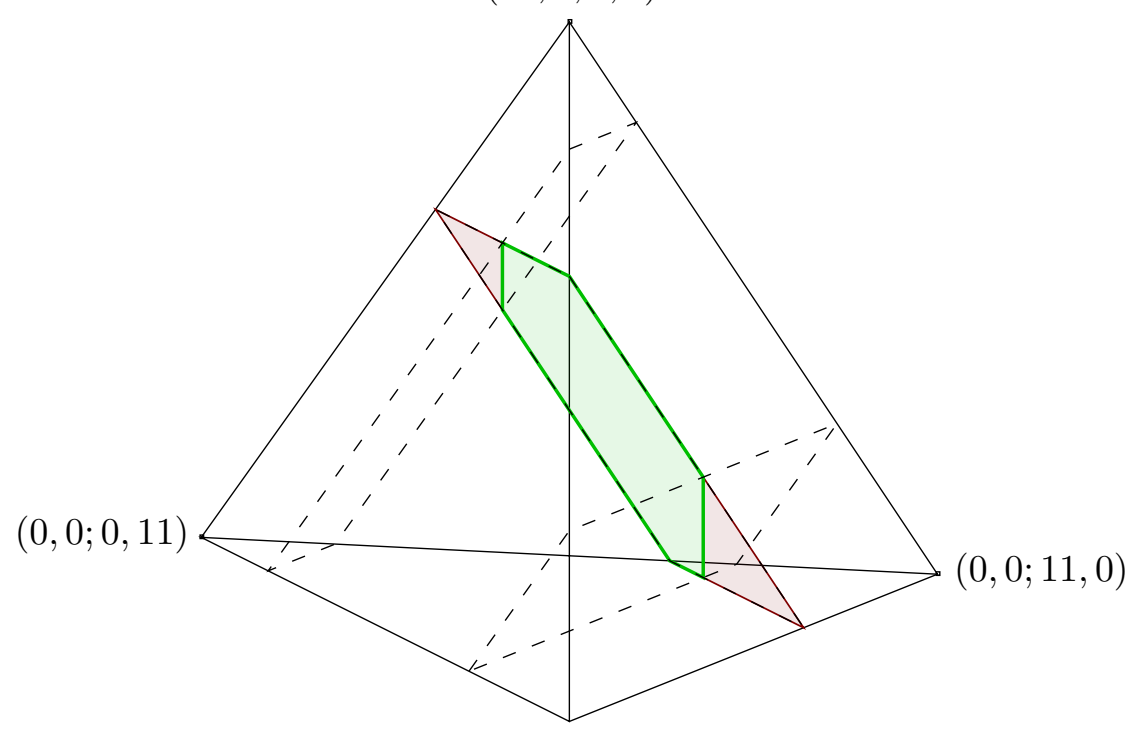

$(0,11 ; 0,0)$

2. ábra. $2+2$ játékos stabil mag, principal section

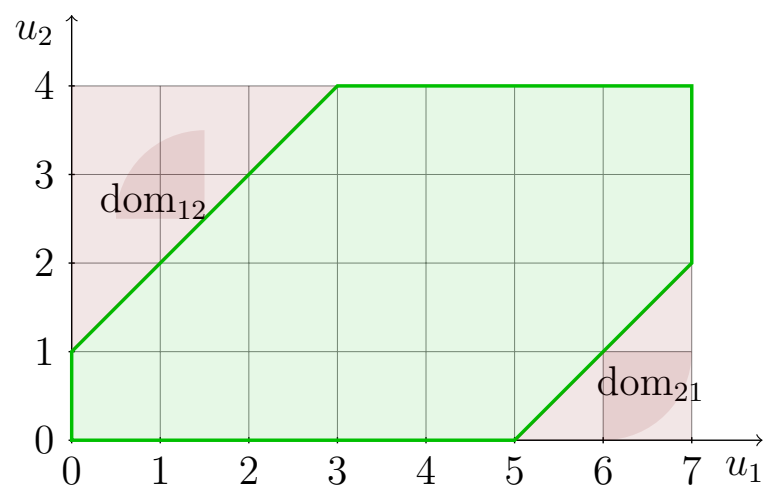


Könnyen meggondolható, hogy a $2+2$ személyes példák mindig így néznek ki. A principal section egy téglalap, a játék magját pedig úgy kaphatjuk meg belőle, ha levágjuk két sarkát két $45^{\circ}$-os egyenessel. az 1.2.2. lemma tartalma sem látszik olyan jól, mert minden vegyespároshoz tartozó magegyenlőtlenség határolja a magot, valamely magelemre egyenlőséként teljesül. Több játékosra viszont ez már nem feltétlenül van így, ahogy az a következő $3+3$ fős példából is látszódni fog.

\section{Példa.}

\begin{tabular}{c|ccc|} 
& $v_{1}$ & $v_{2}$ & $v_{3}$ \\
\hline$u_{1}$ & 8 & 0 & 4 \\
$u_{2}$ & 6 & 8 & 1 \\
$u_{3}$ & 4 & 0 & 8 \\
\hline
\end{tabular}

a 3 . ábrán a 3 . példa principal sectione és magja látható. A principal section az egész kocka. A mag, az az alakzat, ami a pontozott síkok (ahol aktívak a magegyenlőtlenségek) menti vágások után megmarad a kockából. A magnak a principal sectionnel közös lapjait kiszíneztük, hogy jobban látszódjon. Ezen az ábrán már látszik, hogy az előző példával ellentétben szükségünk van az 1.2.2. lemmára, mivel a mag itt nem minden vegyespároson keresztül tud dominálni. Például a $(0,0,8 ; 8,8,0)$ elosztás megszegi a második eladó-harmadik vevő vegyespároshoz tartozó magegyenlőtlenséget, de a mag összes pontjára ez az egyenlőtlenség inaktív, mivel a tagjai minden mag-elosztásban legalább 2-t kapnak, a koalíció értéke pedig csak 1. Viszont ha elhagyjuk ezt a feltételt, akkor látszik, hogy nem változik a játék magja, mert a hozzá tartozó sík nem határolja a magot. az 1.2.4 lemma pedig ebben az esetben azt jelenti, hogy ha a mag bármely pontjából $(1 ; 1 ; 1)$ irányú egyenes mentén indulunk el, és ha beleütközünk a kocka oldalába, akkor megfelelő koordinátát nem növeljük tovább csak a többit, akkor végig a magon belül haladunk. Ebből következik egy másik érdekessége is az ábránknak, ami kicsit összeköti a 2. példával. A játék magját akármelyik lapra levetítve a vetület pont olyan lesz, mint 2 eladó-2 vevő esetén volt a mag, azaz egy levágott sarkú téglalap. A $2+2$ személyes példával ellentétben viszont itt nem minden ilyen „levágás” mentén tud dominálni a mag, elég ha a már említett $u_{2}, u_{3}$ által kifeszített síkra való vetületet nézzük. az 1.2.2. lemma pont azt mondta, ki hogy lesz egy jó vetületünk, ahol a vágás mentén tud dominálni a mag pont mint $2+2$ játékos esetén.

Végül egy $2+2$ személyes példában nézzük meg mi történik, ha nem főátlódomináns a játékot generáló mátrix.

\begin{tabular}{cc|cc|} 
& & $v_{1}$ & $v_{2}$ \\
\hline 4. Példa. & $u_{1}$ & 7 & 3 \\
$u_{2}$ & 5 & 4 \\
\hline
\end{tabular} 


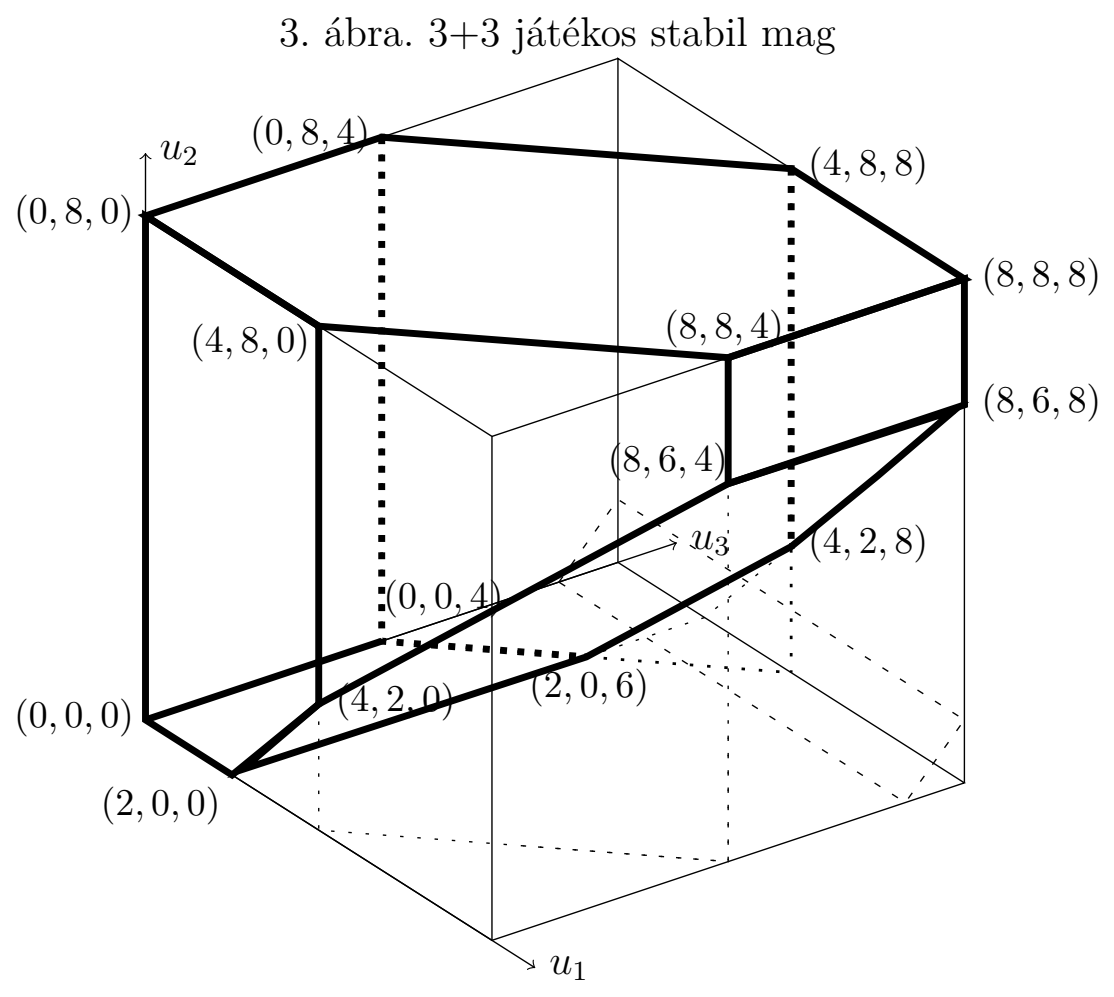

a 4 . példában a 2, példához képest a 2-est megváltoztattuk 5-ösre, a maximális értékü párosítás ettől nem változott, viszont így a mátrix már nem fóátlódomináns, mivel $5=a_{21}>a_{22}=4$. Itt is csak a principal sectiont ábrázoltuk. Mivel nem fóátlódomináns a mátrix, így a mag nem tartalmazza az ábra jobb felső sarkát, az $u_{1}=7, u_{2}=4$ pontot. Ezt a pontot a mag nem is dominálja (söt azokat sem ahol $6<u_{1} \leq 7$ és $u_{2}=4$ ). Ha viszont a maghoz hozzávesszük ezt a felső szakaszt, akkor könnyen látszik, hogy egy stabil halmazt kapunk (a téglalapon kívüli részt dominálja a bal alsó sarkot a jobb felsővel összekötő görbe, a téglalapon belül pedig a mag pontosan azt a felső szakaszt nem dominálja, amelyikkel kiegészítettük. Könnyen lehet látni, hogy $2+2$ játékos esetén ezt mindig meg is tehetjük, ha a magot kiegészítjük a mag vevő- ill eladóoptimális pontjait a principal section ilyen pontjait összekötő szakaszokkal, akkor mindig stabil halmazt fogunk kapni. Több játékos esetén azonban már kérdés leht az is, hogy hogyan egészítsük ki, és a stabilitás sem látszik ilyen könnyen. Ennek a fejezetnek a végén ezt a példát fogjuk általánosítani. Az ottani bizonyításokhoz szükségünk lesz a már említett háló tulajdonságra, és annak néhány következményére, ezért a következő fejezetben előbb ezt fogjuk megvizsgálni. 
4. ábra. $2+2$ játékos nem stabil mag, principal section

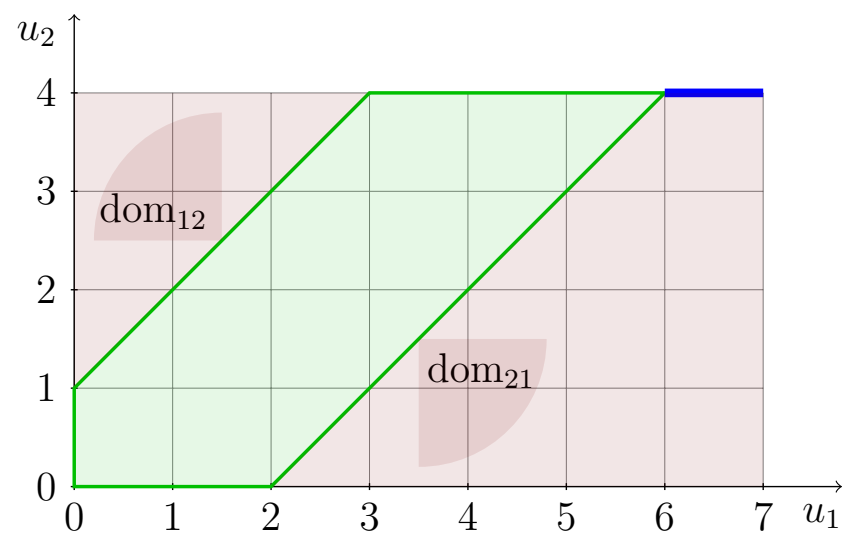

\subsection{Háló tulajdonság és következményei}

A 1.1.11. tételben már megemlítettük a háló tulajdonságot, és hogy a hozzárendelési játék magja rendelkezik vele, de a mag stabilitásának bizonyításában még nem játszott szerepet. A stabil halmaz létezésénél és karakterizációjánál azonban kulcsfontosságú, ezért külön alfejezetben foglalkozunk vele, és néhány következményével. Az ebben a részben található állítások és bizonyítások igazából apróságok, de ha nem hozzárendelési játékokkal foglalkoznánk, akkor a háló tulajdonságot nem is tudnánk rendesen definiálni, így a későbbiekben nem állna rendelkezésre a fö fegyverünk.

1.3.1. Definíció. Egy $\mathcal{X} \subseteq \mathbb{R}^{m} \times \mathbb{R}^{n}$ halmaz háló, ha bármely $\left(\boldsymbol{x}^{1} ; \boldsymbol{y}^{1}\right),\left(\boldsymbol{x}^{2} ; \boldsymbol{y}^{2}\right) \in \mathcal{X}$ elemére $\left(\boldsymbol{x}^{1} \vee \boldsymbol{x}^{2} ; \boldsymbol{y}^{1} \wedge \boldsymbol{y}^{2}\right) ;\left(\boldsymbol{x}^{1} \wedge \boldsymbol{x}^{2} ; \boldsymbol{y}^{1} \vee \boldsymbol{y}^{2}\right) \in \mathcal{X}$

A már tárgyalt 2. példán, nézzük meg, hogy ez geometriailag mit is jelent. A játékot meghatározó mátrix a következő volt:

\begin{tabular}{c|cc|} 
& $v_{1}$ & $v_{2}$ \\
\hline$u_{1}$ & 7 & 3 \\
$u_{2}$ & 2 & 4 \\
\hline az & 5 & ábrán
\end{tabular}

az 5 , ábrán megint a principal sectiont ábrázoltuk a már említett módon. Ahogy azt már korábban is láttuk a játék magja a hatszög. Az, hogy a mag egy háló a következőt jelenti: akárhogy veszünk két pontot a magból (például az eladók $(\boldsymbol{u})$ szempontjából a $(3,3)$ és $(6,1)$ pontokat) a magnak része ezen két pont két hálókombinációja is, azaz azok a pontok amikben az eladók a két elosztás közül rosszabbul, a vevők jobban járnak és fordítva Esetünkben ezek a $(3,3) \vee(6,1)=(6,3)$ és $(3,3) \wedge(6,1)=(3 ; 1)$ pontok. Általában a két pont által a tengelyekkel párhuzamosan kifeszített téglatestnek az eladók szempontjából maximális és minimális csúcsa. 
5. ábra. Háló ábra

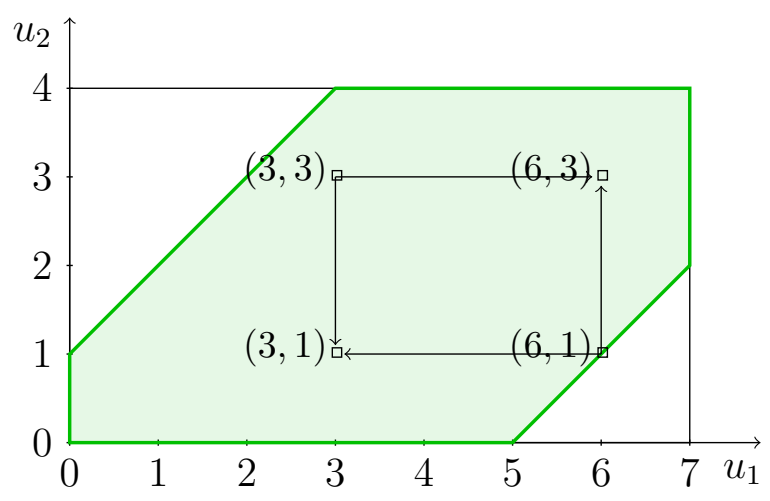

A háló tulajdonságnak szoros kapcsolatát a dominanciával (és ezen keresztül a maggal és a stabil halmazzal) mutatják be a következő állítások.

1.3.2. Állítás. Ha egy vektor dominálja két másik vektor valamely hálókombinációját, akkor a két vektor közül is legalább az egyiket dominálja.

\section{BiZONYÍTÁS.}

Legyen $(\boldsymbol{x} ; \boldsymbol{y})$ a domináló vektor, $\left(\boldsymbol{u}^{1} ; \boldsymbol{v}^{1}\right),\left(\boldsymbol{u}^{2} ; \boldsymbol{v}^{2}\right)$ a másik két vektor, a dominált hálókombinációjuk pedig $\left(\boldsymbol{u}^{1} \vee \boldsymbol{u}^{2} ; \boldsymbol{v}^{1} \wedge \boldsymbol{v}^{2}\right)$ (szimmetria miatt a másik hálókombinációra hasonlóan megy a bizonyítás). Láttuk, hogy hozzárendelési játékokban ha egy vektor dominál egy másikat, akkor egyszemélyes koalíción, vagy vegyespároson keresztül is dominálja.

- Ha egyszemélyes koalíción keresztül dominál $(\boldsymbol{x} ; \boldsymbol{y})$, akkor ugyanezen az egyszemélyes koalíción keresztül dominálja $\left(\boldsymbol{u}^{1} ; \boldsymbol{v}^{1}\right)$ és $\left(\boldsymbol{u}^{2} ; \boldsymbol{v}^{2}\right)$ közül azt, amelyiknek ez a koordinátája kisebb.

- Ha egy $(i ; j)$ vegyespároson keresztül dominál $(\boldsymbol{x} ; \boldsymbol{y})$, akkor ugyanezen a vegyespároson keresztül dominálja $\left(\boldsymbol{u}^{1} ; \boldsymbol{v}^{1}\right)$ és $\left(\boldsymbol{u}^{2} ; \boldsymbol{v}^{2}\right)$ közül azt, amelyiknek a $v_{j}$ koordinátája kisebb, mivel ez a koordináta megegyezik $v_{j}^{1} \wedge v_{j}^{2}$-vel, továbbá az ehhez a vektorhoz tartozó $u_{i}$ koordináta nem lehet nagyobb, mint $u_{i}^{1} \vee u_{i}^{2}$.

1.3.3. Állítás. Ha az elosztáshalmaznak (vagy féleloszáshalmaznak) egy tetszöleges halmaz által nem dominált része belső stabil, akkor háló is. Azaz tetszőleges $\mathcal{X} \subseteq \mathbb{R}^{|P|}$ esetén ha $\mathcal{I} \backslash D(\mathcal{X})$ vagy $\mathcal{I}^{\prime} \backslash D(\mathcal{X})$ belső stabil, akkor háló is. 


\section{BIZONYÍTÁS.}

$\mathcal{I} \backslash D(\mathcal{X})$-re mutatjuk meg, a másikra pontosan ugyanúgy megy a bizonyítás. Vegyük $\mathcal{I} \backslash D(\mathcal{X})$-nek két elemét, és azoknak egy hálókombinációját.

- Ha ez a hálókombináció elosztás, akkor nem dominálhatja $\mathcal{X}$-beli elem, mert ha dominálná, akkor az 1.3.2. állítás miatt dominálná az egyik $\mathcal{I} \backslash D(\mathcal{X})$-beli vektort is, ami lehetetlen. Ez viszont azt jelenti, hogy a hálókombináció eleme $\mathcal{I} \backslash \mathcal{X}$-nek, pont amit meg akartunk mutatni.

- Ha a hálókombináció nem elosztás, akkor vagy ez, vagy a másik hálókombináció szigorú félelosztás kell hogy legyen. Nézzük ezt a szigorú félelosztásvektort. Ezt nem dominálja $\mathcal{X}$-beli vektor, mert akkor az 1.3.2. állítás miatt az dominálná valamelyik $\mathcal{I} \backslash D(\mathcal{X})$-beli vektort is. Növeljük meg ennek a szigorú félelosztásnak minden koordinátáját úgy, hogy egy elosztást kapjunk, és vizsgáljuk ezt a vektort.

- Ez dominálja a megnövelés előtti vektort a nagykoalíción keresztül, így az 1.3 .2 . állítás miatt dominálja valamelyik eredeti $\mathcal{I} \backslash D(\mathcal{X})$-beli vektort is. Ezért $\mathcal{I} \backslash D(\mathcal{X})$ belső stabilitása miatt nem lehet ebben a halmazban.

- Másrészt mivel a növelés előtti hálókombinációt nem dominálta $\mathcal{X}$-beli vektor, így az annál nagyobb vektorokat sem, azaz a megnövelt elosztásunkat sem, ezért viszont a megnövelt vektor eleme $\mathcal{I} \backslash D(\mathcal{X})$ halmaznak,

ez viszont ellentmondás, így $\mathcal{I} \backslash D(\mathcal{X})$ bármely két elemének hálókominációja elosztás kell, hogy legyen.

Ennek az egyszerủ állításnak a következménye, hogy a hozzárendelési játékok magja és stabil halmazai is hálót alkotnak.

\subsection{4. Állítás. Egy hozzárendelési játék magja és stabil halmazai is hálót alkotnak} BIZONYÍTÁS.

Mivel $\mathcal{C}=\mathcal{I} \backslash D\left(\mathcal{I}^{*}\right)$, és ha $\mathcal{V}$ stabil halmaz, akkor $\mathcal{V}=\mathcal{I} \backslash D(\mathcal{V})$, és mindkét halmaz belső stabil, így az 1.3.3 állításból azonnal adódik az állítás.

Érdemes már itt megjegyezni, hogy nyilvánvaló, hogy tetszőleges hozzárendelési játék esetén a principal section hálót alkot, míg az elosztáshalmaz csak nagyon elfajult esetben lesz az. Ezért lesz sokkal egyszerübb a stabil halmaz létezésének a bizonyítása, ahol gyorsan belátjuk, hogy annál a konkrét halmaznál elég a principal sectiont vizsgálni, mint a karakterizációnál található bizonyítás, mivel ott nem tudunk egy hálóra szorítkozni. 
A háló tulajdonságnak több érdekes geometriai következménye is van, melyeket a későbbi bizonyításokban használni is fogunk.

1.3.5. Állítás. $H a\left(\boldsymbol{x}^{1} ; \boldsymbol{y}^{1}\right) ;\left(\boldsymbol{x}^{2} ; \boldsymbol{y}^{2}\right) ;\left(\boldsymbol{x}^{3} ; \boldsymbol{y}^{3}\right) \in \mathcal{X}$ hálónak, akkor $\operatorname{med}\left(\left(\boldsymbol{x}^{1} ; \boldsymbol{y}^{1}\right) ;\left(\boldsymbol{x}^{2} ; \boldsymbol{y}^{2}\right) ;\left(\boldsymbol{x}^{3} ; \boldsymbol{y}^{3}\right)\right) \in \mathcal{X}$, ahol med a koordinátánkénti mediánt jelöli

BizONYÍTÁs.

Az állítás következik a med $(x ; y ; z)=(x \wedge y) \vee(y \wedge z) \vee(z \wedge x)=(x \vee y) \wedge(y \vee z) \wedge(z \vee x)$ egyenlőségből a háló tulajdonság többszöri felhasználásával.

Ez geometriailag kétféleképpen is megfogalmazhatjuk. Vagy azt mondjuk, hogy ha van három vektorunk, és ebből csinálunk egy negyediket, úgy, hogy vesszük koordinátánként a középsőt, ennek az új vektornak is a hálóban kell lennie. Kicsit másképp ez azt jelenti, hogy ha három pont eleme egy hálónak, akkor ha levetítjük ezek közül az egyiket a másik kettő által kifeszített téglatestre, az így kapott pont is eleme kell, hogy legyen a hálónak.

1.3.6. Megjegyzés. Teljesen hasonlóan belátható, hogy ha egy hálóból kiveszünk $r$ darab pontot, és készítünk ezekből egy újat úgy, hogy az eladók koordinátánként az i. legnagyobb, a vevők az $i$. legkisebb értéket kapják, az igy kapott vektor is eleme a hálónak.

1.3.7. Állítás. Legyen $\mathcal{X}$ egy korlátos és zárt háló, és $(\underline{\boldsymbol{u}} ; \overline{\boldsymbol{v}})$ az első koordinátákban minimális a többiben maximális pontja, azaz $\underline{u}_{i}=\min _{(\boldsymbol{u} ; \boldsymbol{v}) \in \mathcal{X}} u_{i}$ és $\bar{v}_{j}=\max _{(\boldsymbol{u} ; \boldsymbol{v}) \in \mathcal{X}} v_{j}$, és hasonlóan $(\overline{\boldsymbol{u}} ; \underline{\boldsymbol{v}})$ az első koordinátákban maximális a többiben minimális eleme. Ekkor az alábbi 3 tulajdonság ekvivalens:

\section{1. $\mathcal{X}$ összefüggő}

2. létezik $(\underline{\boldsymbol{u}} ; \overline{\boldsymbol{v}})$ és $(\overline{\boldsymbol{u}} ; \underline{\boldsymbol{v}})$ pontokat összekötő $\mathcal{X}$-beli görbe.

3. $\mathcal{X}$ bármely két pontját összeköti $\mathcal{X}$-beli koordinátánként monoton görbe.

BIZONYÍTÁs.

Az $1 \Rightarrow 2$ és $3 \Rightarrow 1$ irányok nyilvánvalóak, így elég a $2 \Rightarrow 3$-at bizonyítani.

Legyen $\left(\boldsymbol{x}^{1} ; \boldsymbol{y}^{1}\right),\left(\boldsymbol{x}^{2} ; \boldsymbol{y}^{2}\right) \in \mathcal{X}$, és legyen $\left(\boldsymbol{x}^{3} ; \boldsymbol{y}^{3}\right)=\left(\boldsymbol{x}^{1} \wedge \boldsymbol{x}^{2} ; \boldsymbol{y}^{1} \vee \boldsymbol{y}^{2}\right)$. Elég megmutatni, hogy létezik az $\left(\boldsymbol{x}^{1} ; \boldsymbol{y}^{1}\right)$ és az $\left(\boldsymbol{x}^{3} ; \boldsymbol{y}^{3}\right)$, valamint az $\left(\boldsymbol{x}^{3} ; \boldsymbol{y}^{3}\right)$ és $\left(\boldsymbol{x}^{2} ; \boldsymbol{y}^{2}\right)$ pontokat összekötő koordinátánként monoton görbe, mert a kettő uniója az $\left(\boldsymbol{x}^{1} ; \boldsymbol{y}^{1}\right)$ és $\left(\boldsymbol{x}^{2} ; \boldsymbol{y}^{2}\right)$ pontokat összekötő görbe. Az elsőt fogjuk megmutatni, a második szimmetria miatt ugyanúgy megy. Legyen az $(\underline{\boldsymbol{u}} ; \overline{\boldsymbol{v}})$ és $(\overline{\boldsymbol{u}} ; \underline{\boldsymbol{v}})$ pontokat összekötö monoton görbe $(\boldsymbol{u}(t) ; \boldsymbol{v}(t))_{t \in[0 ; 1]}$. Legyen $\left(\boldsymbol{u}^{\prime}(t) ; \boldsymbol{v}^{\prime}(t)\right)=\operatorname{med}\left(\left(\boldsymbol{x}^{1} ; \boldsymbol{y}^{1}\right) ;(\boldsymbol{u}(t) ; \boldsymbol{v}(t)) ;\left(\boldsymbol{x}^{3} ; \boldsymbol{y}^{3}\right)\right)$. Ek-

kor az 1.3.5. állítás miatt az $\left(\boldsymbol{u}^{\prime}(t) ; \boldsymbol{v}^{\prime}(t)\right)_{t \in[0 ; 1]}$ görbe $\mathcal{X}$-ben van, ami az $\left(\boldsymbol{x}^{1} ; \boldsymbol{y}^{1}\right)$ és 
$\left(\boldsymbol{x}^{3} ; \boldsymbol{y}^{3}\right)$ pontokat köti össze. Hiányzik még a görbe monotonitása. Ehhez legyen $\left(\boldsymbol{u}^{\prime \prime}(t) ; \boldsymbol{v}^{\prime \prime}(t)\right)=\left(\bigwedge_{s \leq t} \boldsymbol{u}^{\prime}(s) ; \bigvee_{s \leq t}\left(\boldsymbol{v}^{\prime}(s)\right)\right.$. Itt nem probléma, hogy végtelen sok elemnek vesszük a hálókombinációját, mivel minden koordinátában létezik olyan elem, ahol a maximum és a minimum fölvétetik, így ez ugyanaz mintha legfeljebb $|P|$ elem hálókombinációját vennénk. Az $\left(\boldsymbol{u}^{\prime \prime}(t) ; \boldsymbol{v}^{\prime \prime}(t)\right)_{t \in[0 ; 1]}$ görbe pedig a definíciójából adódóan koordinátánként monoton, része $\mathcal{X}$-nek és az $\left(\boldsymbol{x}^{1} ; \boldsymbol{y}^{1}\right)$ és $\left(\boldsymbol{x}^{3} ; \boldsymbol{y}^{3}\right)$ pontokat köti össze.

\subsection{Stabil halmaz létezése}

a 4 példában a mátrix nem volt foátlódomináns, ezért az 1.2.1. tétel miatt a játék magja nem stabil. A jobb felső szakasz hozzávételével viszont sikerült kiegészítenünk stabil halmazzá. Ebben a részben megmutatjuk, hogy általában hogy lehet a magot kiegészíteni stabil halmazzá. Ezt a kiegészítését Shapley javasolta, ami később (Shubik, $1984)$ könyvében jelent meg. Általános esetben a külső stabilitást nem tudták bizonyítani, ezt később Núñez \& Rafels (2013) tették meg. Ez a időben körülbelül ugyanakkor készült kicsit hamarabb is, de a másik jelent meg. Mi ezt a másik saját bizonyítást mutatjuk, meg, ami rövidebb, és ahogy a következő fejezetben a karakterizációnál látni fogjuk, elég jól általánosítható.

a 4 példában könnyen látszik, hogy a kiegészített stabil halmaz éppen a principal section magja. Erről a halmazról fogjuk belátni, hogy stabil. Ezt a halmazt a következő egyenlötlenségekkel lehet megadni:

\subsubsection{Definíció.}

$$
\begin{gathered}
\mathcal{C B}_{A, \mu}=\mathcal{C}\left(\mathcal{B}_{A, \mu}\right)= \\
=\left\{(\boldsymbol{u} ; \boldsymbol{v}) \in \mathcal{B}_{A, \mu} \mid \forall i \in M, j \in N: u_{i}=a_{i \mu(i)} \text { vagy } v_{j}=a_{\mu^{-1}(j) j} \text { vagy } u_{i}+v_{j} \geq a_{i j}\right\}
\end{gathered}
$$

A többi jelöléshez hasonlóan az $A$ és $\mu$ indexeket $\mathcal{B}_{A, \mu}$-nél és $\mathcal{C B}_{A, \mu}$-nél is el fogjuk hagyni, ha egyértelmű, hogy melyik játékról, illetve párosításról van szó. Továbbra is feltesszük, hogy a fóátlóban található a $\mu$ maximális értékủ párosítás. A fóátlóban szereplő értékekből készített vektort $\boldsymbol{d}$-vel jelölve, a principal section vevő- és eladóoptimális csúcsai a $(\mathbf{0} ; \boldsymbol{d})$ illetve a $(\boldsymbol{d} ; \mathbf{0})$ koordinátájú csúcsok.

Könnyen látszik, hogy az itt definiált halmaz, tényleg a principal section magja, mivel egy adott $(i ; j)$ vegyespáros azt a részét nem tudja dominálni $\mathcal{B}$-nek, ahol vagy együtt legalább annyit kapnak, amennyi az értékük, vagy valamelyikük megkapja a maximiumot, amit $\mathcal{B}$-n belül kaphat. 
Shapley (Shubik, 1984) valamint Núñez \& Rafels (2013) nem így definiálták a halmazt, hanem mint különböző részjátékok magjainak az uniója. Ehhez vették a játékosoknak a különböző koalícióit, és ezen részhalmaz játékosainak odaadták a teljes összeget amit a $\mu$ párosításban a párjukkal együtt megszereznek (ha a egy, a maximális értékü párosításbeli páros mindkét tagja benne van a halmazban, akkor mindkettő megkapja), majd ezeket a játékosokat elhagyják és az őket tartalmazó koalíciók értékét lecsökkentik a kifizetett összeg nagyságával. Minden ilyen koalícióhoz tartozik egy részjáték, amit $\mu$ kompatibilisnek hívtak, ha a nagykoalíció értéke az eredeti játékban megegyezik a játékból elhagyandó játékosoknak kifizetendő mennyiség és a megmaradó játékosok értékének összegével (azaz ha akiket elhagyunk nem kapnak „túl sokat”). Az ilyen $\mu$ kompatibilis részjátékok magjainak uniója adta meg az általuk vizsgált halmazt. Csak később, a belső stabilitás bizonyításánál mutatták meg, hogy ez éppen az általunk definiált halmaz.

Shubik (1984) példáján megmutatjuk, hogy ez mit is jelent:

5. Példa. \begin{tabular}{c|cccc}
$m_{2}$ & 0 & 4 & 0 & 1 \\
$m_{3}$ & 1 & 0 & 3 & 0 \\
$m_{4}$ & 0 & 5 & 0 & 3 \\
\hline
\end{tabular}

Itt 4 eladó és 4 vevő van, a táblázatban szereplő $4 \times 4$-es táblázat a játékot generáló mátrix, bal oldalt és fent a megfelelő sorokhoz és oszlopokhoz tartozó játékosok neve található. A maximális értékü $\mu$ párosításról könnyen látszik, hogy a fóátlóban van, a nagykoalíció értéke 14. Vegyük például az $m_{1}$ játékosból álló egyszemélyes koalíciót. A hozzá tartozó részjáték a következőképpen néz ki: az $m_{1}$ játékoshoz a $\mu$ maximális értékü párosításban 4-es érték tartozott, így neki odaadjuk ezt a 4-et, majd kitöröljük az első sort, és a maradék $3 \times$ 4-es mátrix alapján számoljuk a koalíciók értékét. Ez a részjáték kompatibilis az eredetivel, mivel $m_{1}$ kapott 4-et, a maradék értéke pedig 10, így még mindig pontosan az eredeti nagykoalíció értékét osztjuk szét. Az $\left\{m_{1}, n_{1}\right\}$ koalícióhoz tartozó részjáték nem lenne kompatibilis, mivel ott $m_{1}$ és $n_{1}$ is kap 4-4 egységet töröljük az első sort és oszlopot, de a maradék értéke 10, így összesen $4+4+10$ et kellene szétosztani, ami több, mint az eredeti 14. Az $\left\{m_{1}, n_{2}\right\}$-höz tartozó részjáték is kompatibilis, mert kifizetünk nekik 4-et, 4-et, töröljük az első sort és a második oszlopot, a maradék $3 \times 3$-as mátrixban a maximális értékű párosítás értéke 6 lesz, tehát összesen $4+4+6$-ot kell szétosztani, ami pont 14 . Viszont az $\left\{m_{2}, n_{1}\right\}$-hez tartozó részjáték már nem kompatibilis, mert $m_{2}$ és $n_{1}$ megkapja a 4-et, 4-et, töröljük az első oszlopot és a második sort, a maradék $3 \times 3$-as mátrixban a maximális értékű párosítás értéke 
10 (amiben a két 5-ös van), így összesen $4+4+10$-et kellene kifizetni, ami több mint az eredeti 14 .

Geometriailag amikor egy ilyen részjátékot nézünk az azt jelenti, hogy megnézzük, hogy a principal section melyik lapján kell kiegészítenünk még a magot, és pont ezeknek a részjátékoknak a magjával egészítjük ki.

Mi azért nem így definiáltuk a halmazt, mert nem lesz szükségünk a $\mu$ kompatibilis részjátékokra. Szerintünk ez a definíció nem fogja meg igazán a stabil halmazok lényegét. Ebben a fejezetben még nem annyira látszik ennek a magyarázata, de a következő, fejezetben a karakterizációnál már érezhető lesz, mivel ott nincs rögzítve egy párosítás, így a $\mu$ kompatibilis részjáték definiálása is nehézkes lenne. A nagy különbség Shapley (Shubik, 1984) bizonyítás terve valamint Núñez \& Rafels (2013) bizonyítása, és az itt bemutatott saját bizonyítás között az, hogy ők a kompatibilis részjátékokkal dolgoztak, és a problémás külső stabilitás bizonyításakor egy lépésben kifizettek néhány játékost elhagyták őket, így egy kompatibilis részjátékhoz jutottak és elég volt ezen belátni a külső stabilitást. Geometriailag ez azt jelenti, hogy a teljes principal section helyett elég volt egy lapjával foglalkozni, így egyre kevesebb dimenziós téglatestük lett.

Mi is használni fogunk egyfajta redukciót, de mi nem a teljes összeget fogjuk kifizetni a játékosoknak, hanem csak egy részét. Ezzel nem hagyjuk el őket teljesen nem lesz kisebb a principal section dimenziója csak a téglatest lesz kisebb. Geometriailag a nagy téglatestről át fogunk térni két pontja által kifeszített kisebb téglatestre. és elég lesz ezen belátni a külső stabilitást.

A mag stabilitásához képest a problémát a 4 a ábrán is látható a magról lelógó dolgok jelentik. Núñez \& Rafels (2013) bizonyításában ezt úgy oldják meg, hogy lemennek a megfelelő lapra, ahol az már nem a magból lelógó dolog lesz, hanem az adott lapon maga a mag, mi pedig áttérünk egy kisebb résztéglatestre, ezzel levágjuk az ilyen kilógó dolgokat. A másik módszerrel ellentétben ezt majd át fogjuk tudni vinni a következő fejezetbe is, ahol nem lesz kiemelt párosítás, így principal section és annak lapjai sem, az elosztáshalmazon belül viszont még mindig át fogunk tudni térni két pont közti kisebb részre így levágva a problémás részeket. Bár az elsoztáshalmaz háló tulajdonságának hiánya miatt ez az itteninél egy kicsit nehezebb lesz.

1.4.1. Tétel. $\mathcal{C B}_{A, \mu}$ halmaz stabil az A mátrixhoz tartozó hozzárendelési játékban, és az egyetlen olyan stabil halmaz, amely része a $\mu$ párositáshoz tartozó principal sectionnek.

Az állítás második fele már a Shubik (1984)-nál is megtalálható (pontosabban az, hogy a principal sectonön belül nem lehet más stabil halmaz ha $\mathcal{C B}$ stabil mivel a stabilitást nem tudták bizonyítani). Ez azért van, mert ha $\mathcal{B}$-ben keresünk egy stabil halmazt, 
akkor annak $\mathcal{B}$-stabilnak is kell lennie, amiből következik, hogy tartalmazza $\mathcal{B}$ magját, ami nem más mint $\mathcal{C B}$. Viszont ha ez a halmaz stabil, akkor nem lehet részhalmaza más stabil halmaznak, így ez az egyetlen stabil halmaz.

$\mathcal{C B}$ stabilitásának bizonyításhoz először belátunk néhány, $\mathcal{C B}$ szerkezetére vonatkozó állítást.

\subsubsection{Lemma. $\mathcal{C B}$ háló.}

\section{BizONYÍTÁs.}

Legyen $\left(\boldsymbol{x}^{1} ; \boldsymbol{y}^{1}\right),\left(\boldsymbol{x}^{2} ; \boldsymbol{y}^{2}\right) \in \mathcal{C B}$. Megmutatjuk, hogy az $\left(\boldsymbol{x}^{1} \vee \boldsymbol{x}^{2} ; \boldsymbol{y}^{1} \wedge \boldsymbol{y}^{2}\right)$ hálókombináció is eleme $\mathcal{C B}$-nak (a másik hálókombinációra hasonlóan be lehet látni). Azt kell megmutatnunk, hogy minden $(i ; j)$ párra $x_{i}^{1} \vee x_{i}^{2}+y_{j}^{1} \wedge y_{j}^{2} \geq a_{i j}$, vagy $x_{i}^{1} \vee x_{i}^{2}=a_{i i} \operatorname{vagy}$ $y_{j}^{1} \wedge y_{j}^{2}=a_{j j}$.

Szimmetria miatt feltehető, hogy $y_{j}^{1} \geq y_{j}^{2}$. Tudjuk, hogy $\left(\boldsymbol{x}^{2} ; \boldsymbol{y}^{2}\right) \in \mathcal{C B}_{A}$, így az $x_{i}^{2}+y_{j}^{2} \geq a_{i j}, \quad x_{i}^{2}=a_{i i}, \quad y_{j}^{2}=a_{j j}$ feltételek közül legalább egy fennáll.

- ha $x_{i}^{2}+y_{j}^{2} \geq a_{i j}$ teljesül, akkor $x_{i}^{1} \vee x_{i}^{2}+y_{j}^{1} \wedge y_{j}^{2} \geq x_{i}^{2}+y_{j}^{1} \wedge y_{j}^{2}=x_{i}^{2}+y_{j}^{2} \geq a_{i j}$ egyenlőtlenségek miatt kész vagyunk.

- ha $x_{i}^{2}=a_{i i}$, akkor $x_{i}^{1} \vee x_{i}^{2}=x_{i}^{2}=a_{i i}$ miatt kész vagyunk.

- ha $y_{j}^{2}=a_{j j}$, akkor $y_{j}^{1} \wedge y_{j}^{2}=y_{j}^{2}=a_{j j}$ miatt vagyunk kész.

1.4.3. Lemma. $\mathcal{C B}$ bármely két pontját összeköti $\mathcal{C B}$-beli koordinátánként monoton görbe.

\section{BIZONYÍTÁs.}

az 1.3.7. állítás miatt elég megmutatni, hogy a $(\mathbf{0} ; \boldsymbol{d})$ és $(\boldsymbol{d} ; \mathbf{0})$ pontokat összeköti $\mathcal{C B}$ beli görbe. Legyen $(\boldsymbol{x} ; \boldsymbol{y}) \in \mathcal{C}_{A}$ és 1.2.3. definíció szerint készítsük el az $\left(\boldsymbol{u}^{(\tau)}, \boldsymbol{v}^{(\tau)}\right)$ görbét $\tau \in\left[-w_{A}(P) ; w_{A}(P)\right]$. Ez a görbe részhalmaza $\mathcal{C} \mathcal{B}$-nek, mivel egy vegyespárosra csak akkor nem teljesül egy magegyenlötlenség, ha többet vonunk le az egyik koordinátából, mint amennyit a másikhoz hozzáadnánk. Ez viszont csak akkor fordulhat elö, ha a növelni kívánt koordinátának már elértük a principal sectionbeli maximumát. A görbe konstrukciójából következik, hogy monoton, és $\left(\boldsymbol{u}^{\left(-w_{A}(P)\right)}, \boldsymbol{v}^{\left(-w_{a}(P)\right)}\right)=(\mathbf{0} ; \boldsymbol{d})$ valamint $\left(\boldsymbol{u}^{\left(w_{A}(P)\right)}, \boldsymbol{v}^{\left(w_{a}(P)\right)}\right)=(\boldsymbol{d} ; \mathbf{0})$

Az a rész, hogy $(\mathbf{0} ; \boldsymbol{d})$ és $(\boldsymbol{d} ; \mathbf{0})$ pontokat összeköti $\mathcal{C} \mathcal{B}$-beli görbe szerepel Shubik (1984)-nál is pont ugyanígy. 
Most már beláthatjuk az 1.4.1. tételt. A belső stabilitás, és az, hogy $\mathcal{C B}$ dominálja a principal sectionön kívüli részt szerepel Shubik (1984)-nál is pont úgy, ahogy itt. A végén viszont nála annyi van, hogy most már csak az maradt, hogy $\mathcal{C B}$ dominálja $\mathcal{B} \backslash \mathcal{C B}$-t és itt vége is, ami igazából a tétel nehéz része.

AZ 1.4.1. TÉTEL BIZONYÍTÁSA.

$\mathcal{C B}$ halmaz belső stabilitása következik a definíciójából, mivel egy halmaz magja, így egyik eleme sem dominálhat másikat, ezért elég a külső stabilitást megmutatni.

Először belátjuk, hogy $\mathcal{C B}$ dominálja az elosztáshalmaz $\mathcal{B}$-n kívüli részét. Ez teljesen hasonló az 1.2.1. tétel bizonyításához. Vegyünk egy $(\boldsymbol{u} ; \boldsymbol{v}) \in \mathcal{I} \backslash \mathcal{B}$ vektort. Erre a vektorra valamelyik $(k ; k)$ vegyespároshoz (ami a maximális súlyú párosításban van) tartozó magegyenlőtlenség nem teljesül. az 1.4 .3 . lemma alapján találunk egy $(\mathbf{0} ; \boldsymbol{d})$ és $(\boldsymbol{d} ; \mathbf{0})$ pontokat összekötő $\mathcal{C} \mathcal{B}$-beli görbét. Ezen görbe minden pontjára a $(k ; k)$ vegyespároshoz tartozó magegyenlőtlenség egyenlöségként teljesül. Vegyük ennek a görbének azt az $(\boldsymbol{x} ; \boldsymbol{y})$ elemét, amelyre $x_{i}=u_{i}+\frac{a_{k k}-u_{i}-v_{j}}{2}$ és $y_{j}=v_{j}+\frac{a_{k k}-u_{i}-v_{j}}{2}$. Ez az $(\boldsymbol{x} ; \boldsymbol{y})$ vektor dominálja $(\boldsymbol{u} ; \boldsymbol{v})$-t a $(k ; k)$ vegyespároson keresztül.

Innentől jön a Shubik (1984)-nál hiányzó rész. Elég sok vektor és jelölés található a bizonyításban, ezért a bizonyítás után egy vázlatos ábrán megpróbáljuk megmutatni, hogy geometriailag mi is történik, aminek segítségével talán könnyebb a bizonyítást is követni.

Megmutatjuk, hogy a $\mathcal{B} \backslash \mathcal{C B}$ halmazt dominálja $\mathcal{C B}$. Ehhez feltesszük, hogy van olyan $(\boldsymbol{u} ; \boldsymbol{v}) \in \mathcal{B} \backslash \mathcal{C B}$ vektor, amit nem dominál $\mathcal{C B}$, majd az 1.3 .2 állítás többszöri felhasználásával mutatunk egy másik vektort, aminek domináltságából következik $(\boldsymbol{u} ; \boldsymbol{v})$ domináltsága, de kevesebb vegyespároshoz tartozó 1.4.1. definícióbeli) egyenlőtlenséghármast szeg meg $(\boldsymbol{u} ; \boldsymbol{v})$-nál. Ezt a lépést elég sokszor ismételve ellentmondáshoz jutunk. Innentől elég sokszor vesszük két elem hálókombinációját, de mivel a principal sectionön belül vegyunk ez nem jelent problémát, a hálókombináció nem vezet ki a halmazból.

Tegyük fel, hogy létezik $(\boldsymbol{u} ; \boldsymbol{v}) \in \mathcal{B} \backslash \mathcal{C B}$ vektor, amelyet nem dominál $\mathcal{C B}$. Mivel $(\boldsymbol{u} ; \boldsymbol{v}) \notin \mathcal{C B}$, így megszeg egy $(i ; j)$ vegyespároshoz tartozó egyenlőtlenség-hármast, azaz $u_{i}<a_{i i}, \quad v_{j}<a_{j j} \quad$ és $u_{i}+v_{j}<a_{i j}$. az 1.4.3. lemmában beláttuk, hogy $\mathcal{C B}$ összefüggö, így van olyan $(\boldsymbol{x} ; \boldsymbol{y})$ eleme, amelyre $x_{i}>u_{i}, \quad y_{j}>v_{j}, \quad x_{i}-y_{j}=u_{i}-v_{j}$ és az ilyen tulajdonságú $(\boldsymbol{x} ; \boldsymbol{y})$-ok közül az $x_{i}+y_{j}$ összeg minimális. Tudjuk továbbá, hogy erre a pontra $x_{i}+y_{j}>a_{i j}$, mert különben $(\boldsymbol{x} ; \boldsymbol{y})$ dominálná $(\boldsymbol{u} ; \boldsymbol{v})$-t. Most készítünk egy új, $\left(\boldsymbol{u}^{2} ; \boldsymbol{v}^{2}\right)$ vektort.

- Ha $(\boldsymbol{u} \vee \boldsymbol{x} ; \boldsymbol{v} \wedge \boldsymbol{y}) \notin \mathcal{C B}$ akkor legyen ez a vektor az $\left(\boldsymbol{u}^{2} ; \boldsymbol{v}^{2}\right)$ 
- Ha $(\boldsymbol{u} \vee \boldsymbol{x} ; \boldsymbol{v} \wedge \boldsymbol{y}) \in \mathcal{C B}$, akkor abban az esetben ha ez a pont nincs $\mathcal{C B}$-ben. Ha benne van, akkor válasszunk egy $\left(\boldsymbol{x}^{\prime} ; \boldsymbol{y}^{\prime}\right) \in \mathcal{C B}$ pontot úgy, hogy $x_{i}^{\prime}=x_{i}-\epsilon$ legyen egy nagyon kis $\left(x_{i}-u_{i}\right.$-nál és $y_{j}-v_{j}$-nél kisebb) $\epsilon$-ra, majd legyen $\left(\boldsymbol{u}^{2} ; \boldsymbol{v}^{2}\right)=$ $\left(\boldsymbol{u} \vee \boldsymbol{x}^{\prime} ; \boldsymbol{v} \wedge \boldsymbol{y}^{\prime}\right)$. Ebben az esetben $\left(\boldsymbol{u}^{2} ; \boldsymbol{v}^{2}\right)$ biztos nem eleme $\mathcal{C B}$-nek, mert ha az lenne, akkor az 1.4.3. lemma miatt van $\left(\boldsymbol{x}^{\prime} ; \boldsymbol{y}^{\prime}\right)$ és $\left(\boldsymbol{u}^{2} ; \boldsymbol{v}^{2}\right)$ pontokat összekötő $\mathcal{C B}$ beli görbe. Ennek a görbének minden pontjában az $i$. vevö kifizetése $x_{i}^{\prime}=x_{i}-\epsilon$, így az a pontja amelyikben a $j$. vevő kifizetése $y_{j}-\epsilon$ jobb lett volna $(\boldsymbol{x} ; \boldsymbol{y})$ nál annak megválasztásakor, mivel ez is eleme $\mathcal{C B}$-nek, de itt az $(\mathrm{i} ; \mathrm{j})$ vegespáros kifizetése kisebb, mint $(\boldsymbol{x} ; \boldsymbol{y})$-ban

Mindkét esetben kaptunk egy $\left(\boldsymbol{u}^{2} ; \boldsymbol{v}^{2}\right) \notin \mathcal{C B}$ pontot. az 1.3.2. állítás miatt elég megmutatnunk, hogy $\mathcal{C B}$ halmaz dominálja $\left(\boldsymbol{u}^{2} ; \boldsymbol{v}^{2}\right)$-t, abból már következik hogy $(\boldsymbol{u} ; \boldsymbol{v})$-t is dominálja, mert $\left(\boldsymbol{u}^{2} ; \boldsymbol{v}^{2}\right)$ vektort két vektor hálókombinációjaként kaptuk, így ha valami dominálja ezt, akkor az dominálja a másik kettő közül is valamelyiket, de mivel $(\boldsymbol{x} ; \boldsymbol{y})$ és $\left(\boldsymbol{x}^{\prime} ; \boldsymbol{y}^{\prime}\right) \in \mathcal{C B}$ volt, így csak $(\boldsymbol{u} ; \boldsymbol{v})$-t dominálhatja.

Most $(\boldsymbol{u} ; \boldsymbol{v})$ helyett $\left(\boldsymbol{u}^{2} ; \boldsymbol{v}^{2}\right)$-ról kell belátnunk, hogy dominálja $\mathcal{C B}$. Ez azért jó nekünk, mert amelyik egyenlőtlenség hármast $(\boldsymbol{u} ; \boldsymbol{v})$ teljesítette, azt $\left(\boldsymbol{u}^{2} ; \boldsymbol{v}^{2}\right)$ is teljesíti. az 1.4.2. lemmában igazából azt láttuk be, hogy ha két vektor teljesíti ugyanazt az egyenlőtlenség hármast, akkor ezek hálókombinációi is, továbbá $u_{i}^{2}+v_{j}^{2}>u_{i}+v_{j}$, azaz az új vektor egy kicsit „kevésbé szegi meg” az $(i ; j)$ vegyespároshoz tartozó magegyenlőtlenséget, de ami most igazán lényeges, hogy eddig csak azt tudtuk mondani, hogy azokra az $(\boldsymbol{s} ; \boldsymbol{t}) \in \mathcal{C B}$ pontokra, amelyekre $s_{i}>u_{i}$ és $t_{j}>v_{j}$ teljesülnie kell az $s_{i}+t_{j}>a_{i j}$ egyenlőtlenségnek, addig $\left(\boldsymbol{u}^{2} ; \boldsymbol{v}^{2}\right)$-vel ugyanitt $s_{i} \geq u_{i}^{2}$-re mondhatjuk ki ugyanezt (mert $u_{i}^{2}>u_{i}$ ).

Csináljuk meg az előző lépést $\left(\boldsymbol{u}^{2} ; \boldsymbol{v}^{2}\right)$-ból kiindulva szimmetrikusan a másik hálókombinációt véve. Az így kapott elem legyen $\left(\boldsymbol{u}^{3} ; \boldsymbol{v}^{3}\right)$. Most már igaz az, hogy minden $(\boldsymbol{s} ; \boldsymbol{t}) \in \mathcal{C B}$ elosztásra, amelyre $s_{i} \geq u_{i}^{3}$ és $t_{j} \geq v_{j}^{3}$ teljesülnie kell az $s_{i}+t_{j}>a_{i j}$ egyenlőtlenségnek. Legyen $\epsilon_{2}=\min _{(s ; t) \in \mathcal{C B}: s_{i} \geq u_{i}^{3}, t_{j} \geq v_{j}^{3}} s_{i}+t_{j}-a_{i j}$. Ez az érték létezik (mivel egy korlátos és zárt halmazon minimalizálunk egy folytonos függvényt) és pozitív (ami nem biztos, hogy igaz, ha $\left(\boldsymbol{u}^{3} ; \boldsymbol{v}^{3}\right)$ helyett $(\boldsymbol{u} ; \boldsymbol{v})$-t vesszük).

Ha az előző lépést ismételgetjük, akkor most már tudunk mondani egy konkrét értéket, hogy ha az új $\left(\boldsymbol{u}^{k} ; \boldsymbol{v}^{k}\right)$ nem teljesíti az $(i ; j)$ pároshoz tartozó magegyenlőtlenséget, akkor legalább $\frac{\epsilon_{2}}{2}$-vel több kifizetést kapnak, mint $\left(\boldsymbol{u}^{k-1} ; \boldsymbol{v}^{k-1}\right)$-ben (ha nincs szükség $\left(\boldsymbol{x}^{\prime} ; \boldsymbol{y}^{\prime}\right)$-re akkor mondhattunk volna $\epsilon_{2}$-t is, de ha szükség van rá, akkor az $\epsilon$ meghatározásánál vegyük bele azt a feltételt is, hogy legyen kisebb mint $\frac{\epsilon_{2}}{2}$ ).

Így véges sok lépésben kapunk egy olyan $\mathcal{B} \backslash \mathcal{C B}$-beli elosztást, amely kevesebb vegyespároshoz tartozó egyenlőtlenség hármast szeg meg mint $(\boldsymbol{u} ; \boldsymbol{v})$. Most csináljuk meg 
ugyanezt az új elosztással... Így véges sok lépés után kapunk egy $\mathcal{B} \backslash \mathcal{C B}$ elosztást, amely nem szeg meg egyenlőtlenség hármast, ami ellentmondás.

A bizonyítás megértésében segít, ha ábrázoljuk az $(i ; j)$ vegyespáros kifizetését megadó síkon, hogy mit is csinálunk.

6. ábra. $\mathcal{C B}$ stabil bizonyítása 1

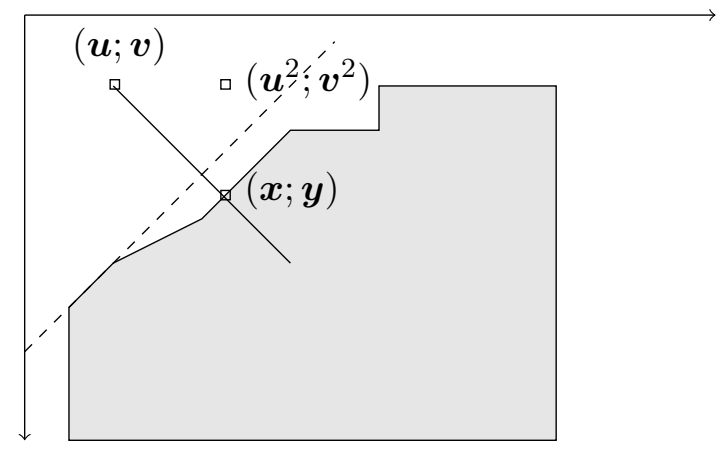

a 6 , ábrán az i. eladó kifizetése $\left(u_{i}\right.$ és $x_{i}$ koordináták) szerepelnek a vízszintes tengelyen balról jobbra, a j. vevő kifizetése $\left(v_{j}\right.$ és $\left.y_{j}\right)$ pedig a függólegesen felülről lefelé. Elsőre furcsa lehet, hogy a $j$. vevő kifizetése miért lefelé nő. Azért választottuk így, mert a principal sectionön belül a megfelelö eladó vevő páros összkifizetése fix, így a j. eladó kifizetése „rendesen” alulról fölfele nő, a bal alsó sarok így az eladók számára minimális a jobb felső pedig a maximális kifizetést adó vektor. A szaggatott vonal mentén aktív az $(i ; j)$ pároshoz tartozó magegyenlőtlenség, a szürke síkidom pedig a $\mathcal{C B}$ halmaz vetülete a síkra. A pontos alakja most nem érdekel minket, elég ha annyit tudunk róla, hogy bármely két pontját összeköti monoton $\mathcal{C} \mathcal{B}$-beli görbe. A bal felső pont az $(\boldsymbol{u} ; \boldsymbol{v})$, amit dominálni akarunk, azt tudjuk róla, hogy nincs $\mathcal{C} \mathcal{B}$-ben, mert megszegi az $(i, j)$ párhoz tartozó egyenlőtlenséghármast, azaz a szaggatott vonaltól balra felfele van, és nincs a principal section alsó illetve jobb oldalán. Elöször meghatározzuk az $(\boldsymbol{x} ; \boldsymbol{y})$ pontot, úgy, hogy az $(\boldsymbol{u} ; \boldsymbol{v})$ pontból elindítunk egy -1 meredekségű félegyenest, és ahol elöször metszi $\mathcal{C B}$-t ott van $(\boldsymbol{x} ; \boldsymbol{y})$. Ilyen pont biztos van, mert a $\mathcal{C B}$ halmaz eladók számára minimális és maximális pontját összeköti egy monoton görbe. Ezt valahol el kell metszenie az egyenesnek. Ez a pont biztos, hogy a szaggatott vonaltól szigorúan jobbra lefele van, ellenkező esetben $(\boldsymbol{x} ; \boldsymbol{y})$ dominálná $(\boldsymbol{u} ; \boldsymbol{v})$-t és kész is lennénk.

Utána vesszük $(\boldsymbol{u} ; \boldsymbol{v})$ és $(\boldsymbol{x} ; \boldsymbol{y})$ hálókombinációját. a 6. ábrán az első egyszerűbb eset van, amikor ez a hálókombináció nem eleme $\mathcal{C B}$-nek. Ekkor ez a hálókombináció lesz $\left(\boldsymbol{u}^{2} ; \boldsymbol{v}^{2}\right)$. Innentől elég megmutatni, hogy $\left(\boldsymbol{u}^{2} ; \boldsymbol{v}^{2}\right)$-t dominálja $\mathcal{C B}$. Az $\left(\boldsymbol{u}^{2} ; \boldsymbol{v}^{2}\right)$ pont viszont már közelebb van a szaggatott vonalhoz, mint az eredeti. Most nézzük a második problémásabb esetet. 
7. ábra. $\mathcal{C B}$ stabil bizonyítása 2

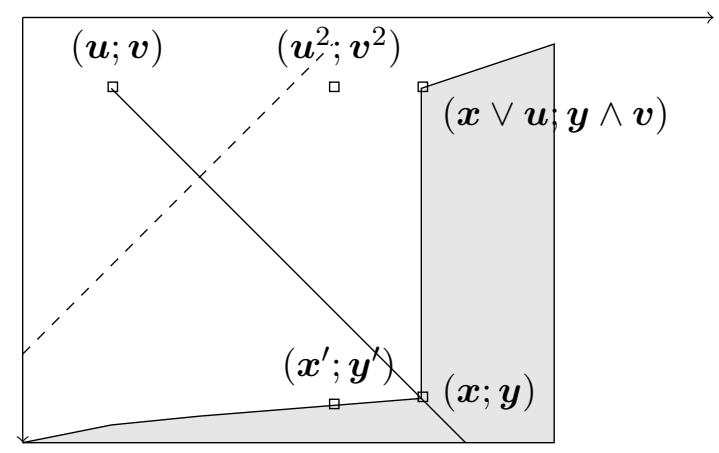

A problémásabb eset, amikor a hálókombináció nincs $\mathcal{C B}$-ben. Ezt vázoljuk fel a 7 . ábrán. Itt nincs szerencsénk és a hálókombináicó eleme $\mathcal{C B}$-nek. Ekkor sincs nagy baj, mert veszünk $(\boldsymbol{x} ; \boldsymbol{y})$-tól egy kicsit balra egy másik pontját $\mathcal{C B}$-nek ez az $\left(\boldsymbol{x}^{\prime} ; \boldsymbol{y}^{\prime}\right)$. Ilyen biztos van, mert $(\boldsymbol{x} ; \boldsymbol{y})$-t köti össze $\mathcal{C} \mathcal{B}$-beli görbe a vevőoptimális bal alsó sarokkal. Pont ezért az is biztos, hogy $y_{j}^{\prime} \geq y_{j}$ azaz az új pont az eredetinél nem lehet feljebb az ábrán. Most vesszük $\left(\boldsymbol{x}^{\prime} ; \boldsymbol{y}^{\prime}\right)$ pontnak és $(\boldsymbol{u} ; \boldsymbol{v})$-nek a megfelelő hálókombinációját ez lesz $\left(\boldsymbol{u}^{2} ; \boldsymbol{v}^{2}\right)$. Ez a vektor nem lehet eleme $\mathcal{C B}$-nek, mert ha az lenne, akkor lenne monoton $\mathcal{C B}$-beli görbe $\boldsymbol{x}^{\prime} ; \boldsymbol{y}^{\prime}$ és $\left(\boldsymbol{u}^{2} ; \boldsymbol{v}^{2}\right)$ között (a vetületünkön ez egy függőlges szakasz lenne), ennek viszont van olyan pontja ami az $(\boldsymbol{u} ; \boldsymbol{v})$ és $(\boldsymbol{x} ; \boldsymbol{y})$ pontokat összekötő szakaszt $(\boldsymbol{u} ; \boldsymbol{v})$-hez közelebb metszené, ami nem lehet $(\boldsymbol{x} ; \boldsymbol{y})$ választása miatt, mivel $(\boldsymbol{x} ; \boldsymbol{y})$-t pont úgy választottuk, hogy a vetületen a -1 meredekségü egyenesen a legközelebb legyen $(\boldsymbol{u} ; \boldsymbol{v})$-hez. Ebben az esetben is kaptunk egy új pontot, ami közelebb van a szaggatott vonalhoz (esetleg már a másik oldalán is) mint az eredeti.

Egy apró technikai dolog maradt, hogy elképzelhető lenne, hogy hiába lépkedük egyre közelebb a szaggatott vonalhoz sose érjük el és lépünk át rajta. Itt kellett még egy kicsit figyelni. Az ábrán ha $\mathcal{C B}$-nek az $(\boldsymbol{u} ; \boldsymbol{v})$-től nem szigorúan balra lefelé lévő részét nézzük, akkor az végig a szaggatott vonal alatt kell hogy legyen, ellenkezö esetben a megfelelő pont dominálná $(\boldsymbol{u} ; \boldsymbol{v})$-t. Egy apró kivétel van, $(\boldsymbol{u} ; \boldsymbol{v})$-től pontosan lefelé illetve jobbra még éppen elérheti a vetület a szaggatott vonalat, ahogy a 6. ábrán is. Viszont amikor megcsináljuk ezt a lépést, és „,jobbra lépünk egy kicsit”, akkor már ez sem fordulhat elő. Ha ugyazezt a lépést a másik hálókombinációval is elvégezzük, akkor a másik oldalon sem lehet ilyen.

Innentől feltehetö, hogy $\mathcal{C B}$ vetületének a dominálni kívánt ponttól balra lefelé eső része szigorúan a szaggatott vonal alatt van. Ebben az esetben ennek a résznek van egy minimális távolsága a szaggatott vonaltól, így tudunk mondani egy távolságot amennyit minden lépésben legalább haladunk, így előbb-utóbb át kell lépnünk a vonalon. 
Felmerülhet egy elég természetes kérdés $\mathcal{C B}$ szerkezetével kapcsolatban. az1.2.1. tétel bizonyítása során megmutattuk, hogy bármely vegyespáros kifizetését megadó síkra levetítjük a magot ugyanúgy néz ki, mint egy $2+2$ játékossal rendelkező hozzárendelési játék magja. Ha ugyanez igaz lenne $\mathcal{C B}$-re is, azaz hogy minden vetület ugyanúgy néz ki mint egy $2+2$-es játékban a $\mathcal{C B}$ halmaz, azaz a levágott sarkú téglalap mag plussz egy vagy két szakasz, akkor sokkal egyszerübben is beláthattuk volna a tételt. A következő példából látszik, hogy ez nem teljesül.

6. Példa.

\begin{tabular}{c|ccc|} 
& $v_{1}$ & $v_{2}$ & $v_{3}$ \\
\hline$u_{1}$ & 4 & 6 & 0 \\
$u_{2}$ & 0 & 4 & 0 \\
$u_{3}$ & 3 & 0 & 4 \\
\hline
\end{tabular}

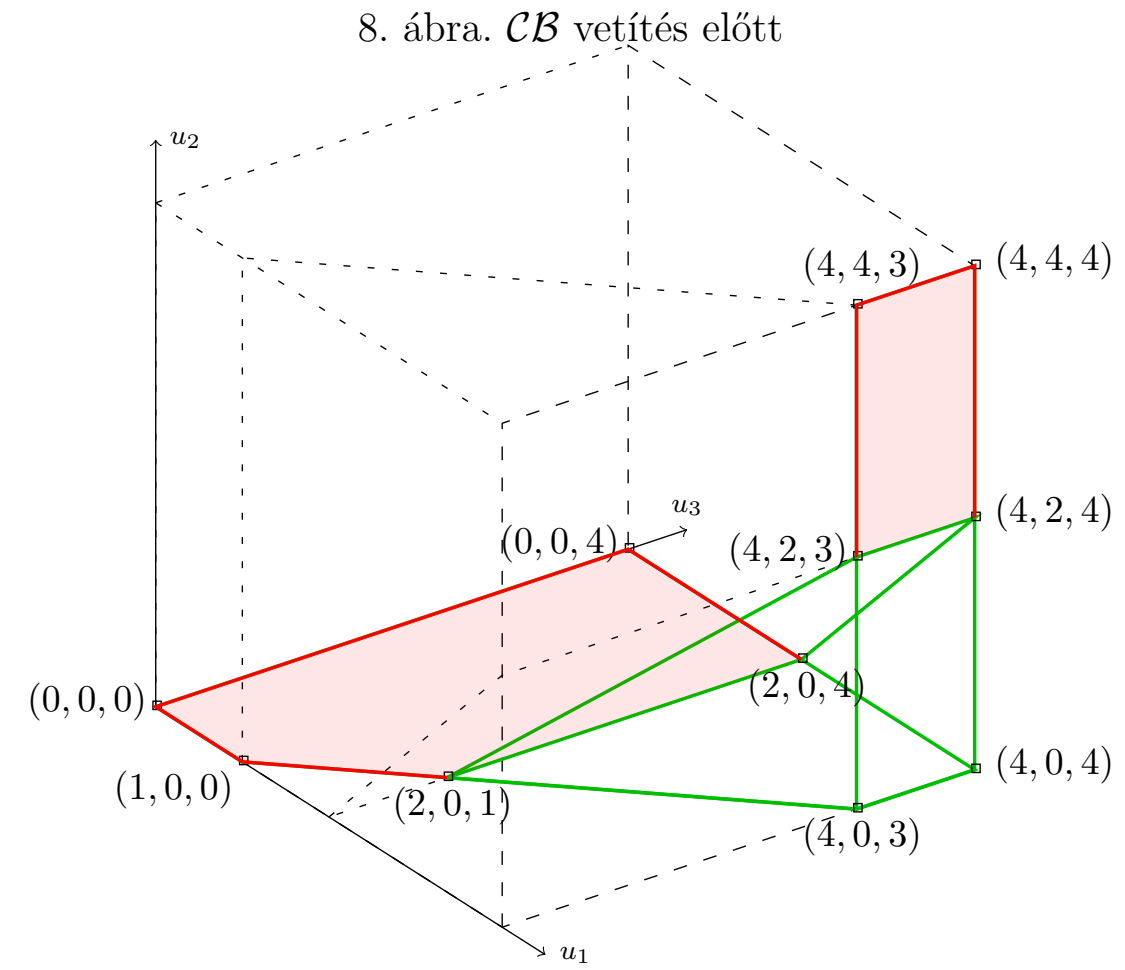

a 8 ábrán a játék magja a $(2,0,1),(4,0,3),(4,0,4),(2,0,4),(4,2,3)$ és $(4,2,4)$ pontok által meghatározott poliéder, $\mathcal{C B}$-t pedig úgy kapjuk meg, hogy hozzávesszük a $(0,0,0),(1,0,0),(2,0,1),(2,0,4),(0,0,4)$ pontok által meghatározott „levágott sarkú téglalapot" és a $(4,2,3),(4,2,4),(4,4,4),(4,4,3)$ téglalapot. Ennek a halmaznak a jobb elülső lapra (2. és 3. koordináta által kifeszített sík) való vetülete szerepel a 9. ábrán. Ilyet nem kaphatunk egy $2+2$-es játék $\mathcal{C B}$ halmazaként, mivel azok levágott sarkú téglalapokból (a játék magja) és legfeljebb két szakaszból állnak. 


\section{9. ábra. $\mathcal{C B}$ vetülete}

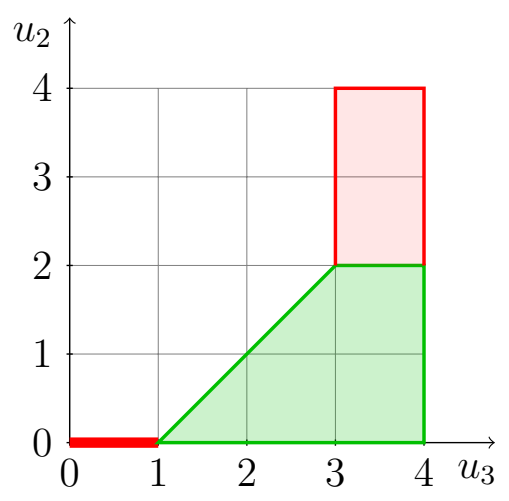

Egy másik érdekes kérdés lehet, hogy $\mathcal{B}$ és ezen keresztül a $\mathcal{C B}$ halmaz definiálásakor volt egy kiemelt maximális súlyú párosításunk. Mi a helyzet, ha több ilyen párosítás is van? Mindegy, hogy melyiket választjuk? A válasz nem. Könnyen látszik, hogy ha másik párosítást választunk, általában más lesz a principal section vevő- és eladóoptimális csúcsa, így ezek magja is különbözni fog. A következő példában ezt mutatjuk be.

7. Példa. $\left[\begin{array}{ll}8 & 6 \\ 6 & 4\end{array}\right]$

Látszik, hogy mindkét párosítás maximális értékü. A játék magja a $(2,0 ; 6,4)$ és $(6,4 ; 2,0)$ pontokat összekötő szakasz. Ha a fóátlóbeli párosítást választjuk ki, és az ehhez tartozó $\mathcal{C B}_{A}, \nu$ halmazt készítjük el, akkor a magot a $(0,0 ; 8,4)$ és $(2,0 ; 6,4)$ pontokat valamint a $(6,4 ; 2,0)$ és $(8,4 ; 0,0)$ pontokat összekötő szakaszokkal egészítjük ki stabil halmazzá, ha viszont a másik párosítást, akkor a $(0,0 ; 6,6)$ és $(2,0 ; 6,4)$ pontokat valamint a $(6,4 ; 2,0)$ és $(6,6 ; 0,0)$ pontokat összekötő szakaszokkal. Ez a kettőt együtt ábrázoltuk az elosztás-tetraéderben a 10, ábrán. A különböző kiegészítéseket különböző színekkel jelöltük.

a 11 e és a 12 ábrákon pedig külön külön ábrázoltuk a két stabil halmazt a megfelelő principal sectionökben.

Könnyen meg lehet mutatni, hogy nem csak ez a két stabil halmaz van, hanem végtelen sok. A magot nem csak ezen a két módon egészíthetjük ki stabil halmazzá, hanem a mag vevő optimális pontjából tetszőleges a vevők kifizetésében monoton nővő az eladókéban monoton csökkenő görbével, amelynek a végén mindkét eladó kifizetése 0. A másik oldalon hasonlóan csak fordított leosztással. a 10, ábrán ez a piros illetve kék vonalak által meghatározott háromszögekbeli monoton görbéket jelent, amelyek vége a háromszög harmadik oldalán van.

Most, hogy láttuk, nem csak $\mathcal{C B}$ típusú stabil halmazok vannak, sőt a 7 . példában láttuk, hogy a végtelen sokból csak 2 stabil halmaz ilyen, érdemes tovább folytatni 
10. ábra. Két $\mathcal{C B}$ stabil halmaz együtt

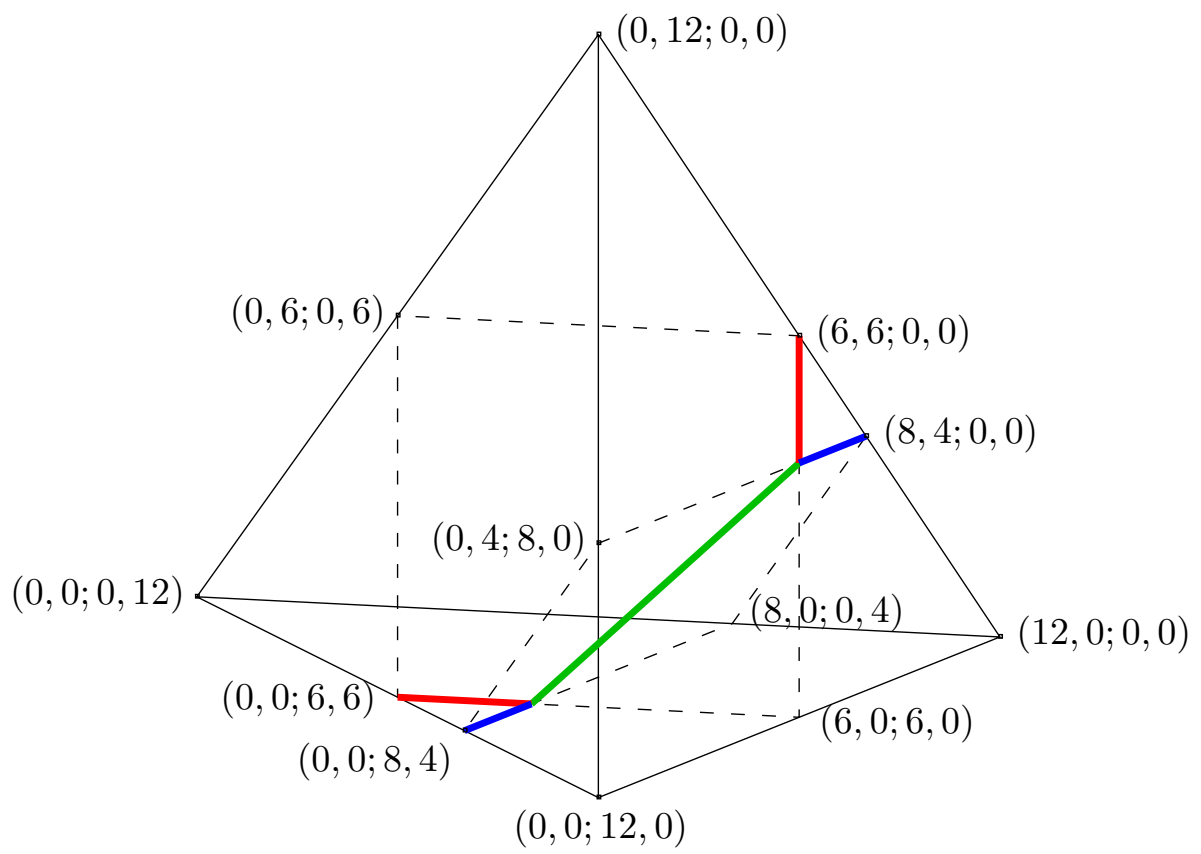

11. ábra. Első $\mathcal{C B}$ halmaz

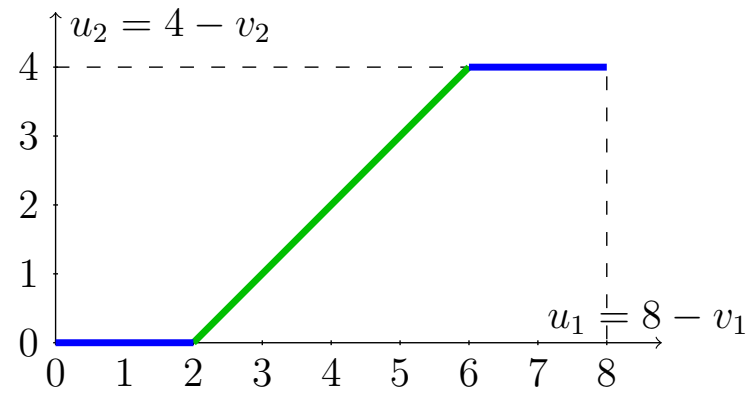

a keresést. A példában leírt stabil halmazok valamilyen értelemben elég hasonlóak, mindegyik egy-egy monoton görbe, amelynek az egyik végén az eladók, a másikon a vevők nem kapnak semmit. Kérdés, hogy általában is van ilyen hasonlóság, tudunk-e általában mondani valamit a stabil halmazok szerkezetéről? Ezt fogjuk megvizsgálni a következő részben. 
12. ábra. Második $\mathcal{C B}$ halmaz

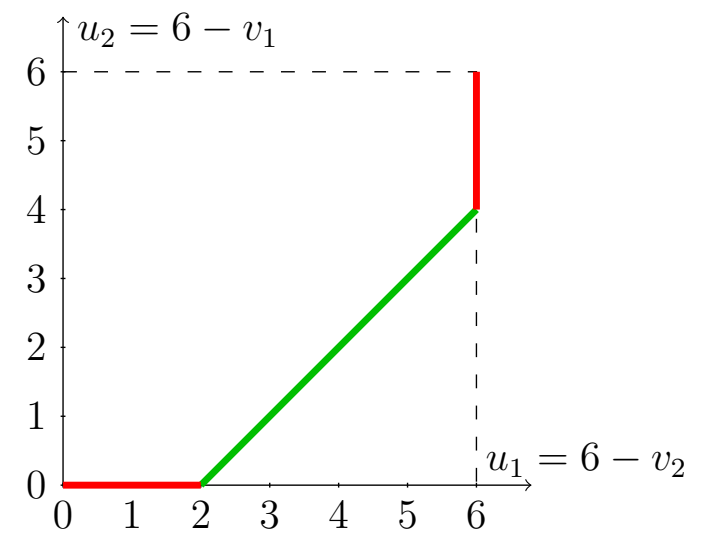

\section{A stabil halmazok karakterizációja}

\subsection{Karakterizáció}

Ha jobban megnézzük a külső stabilitás bizonyítását, láthatjuk hogy $\mathcal{C B}$ összefüggősége és háló tulajdonsága volt fontos. Azt hogy a halmaz elemei melyik egyenlötlenségeket teljesítik és melyikeket nem, két helyen használtuk. Elöször akkor, amikor a második részhez képest egyszerüen megmutattuk, hogy $\mathcal{C B}$ dominálja a $\mathcal{B}$-n kívüli elosztásokat. Ez azért volt fontos, mert a második részben amikor már $\mathcal{B}$-beli elemekkel dolgoztunk, nyugodtan vehettük bármely két elem hálókombinációját, az is egy $\mathcal{B}$-beli elosztás volt. Ugyanez az elosztáshalmazon nem lett volna igaz. Akkor használtuk továbbá, amikor megmutattuk hogy véges sokszor kell elvégezni a hálókombinációs lépést az ellentmondáshoz.

Ebben az alfejezetben ezt a bizonyítást fogjuk általánosítani, megadunk három tulajdonságot, amivel helyettesíthető a külső stabilitás. Ezeknek a tulajdonságoknak a meglétét sok esetben könnyebb ellenőrizni, valamint további érdekes következményeik vannak a stabil halmazok szerkezetére vonatkozóan.

A stabil halmazok karakterizációjával kapcsolatban érdekes lehet megnézni mi a helyzet a hozzárendelési játékokhoz sok szempontból nagyon hasonló házaspárosításos játékoknál (Gale \& Shapley, 1962). Ezen játékosztályon ismert a (NeumannMorgenstern értelemben) stabil halmazoknak egy „majdnem karakterizációja” (Ehlers, 2007). Azért csak majdnem, mert megad néhány szükséges feltételt, és ha csak egy halmaz van, ami kielégíti ezeket, akkor az a halmaz biztos, hogy stabil. Viszont ha több ilyen is van, akkor elképzelhetö, hogy nem lesz az.

A házaspárosítás modellje nem TU játék, nincs egy olyan jószág amit a játékosok egymás közt átadhatnak, és mindenkinek ugyanannyit ér. A játékosok ott is két 
diszjunkt csoportra oszthatóak, nevezzük ezt a két csoportot fiúknak és lányoknak. Ahelyett, hogy egy összeget osztanánk szét köztük, egy (nem feltétlen teljes) párosítást fogunk csinálni. Mindkét nem tagjainak van egy szigorú preferenciasorrendje a másik nemre vonatkozóan, hogy kivel mennyire szeretnének egy párba kerülni. Az a lehetöség is közte van pluszban hogy nincs párjuk. A dominanciát a hozzárendelési játékhoz hasonlóan tudjuk értelmezni két párosítás között. Egy párosítás dominál egy másikat, valamilyen $S$ koalíción keresztül, ha az $S$ tagjai csak egymás között létre tudnak hozni, egy olyan párosítást, amely mindegyikük számára jobb, mint az eredeti. Az, hogy csak egymás közt csinálhatnak párokat felel meg az elérhetőségnek, az, hogy mindegyikük számára jobbnak kell lennie, pedig annak TU esetben a domináló vektornak elönyösebbnek kell lennie.

Nagyon sok hasonlóság van a két modell között. Könnyen látszik, hogy a házaspárosítás esetében is, ha egy párosítás dominál egy másikat, akkor dominálja egy egy-, vagy vegyes kétszemélyes (fiú-lány) koalíción keresztül is. További hasonlóság, hogy a mag (a semmilyen párosítás által nem dominált párosítások halmaza) nem üres és háló szerkezetű, ahol a háló szerkezetet hasonlóan definiáljuk, mint a TU játékok esetében. Két párosítás hálókombinációján azt a két másik párosítást értjük, ahol az egyikben az összes fiú a kettő közül a számára rosszabb, lányt, az összes lány pedig a számára jobb fiút kapja és fordítva. Többek között ezekért az eredményekért kapott 2012-ben Nobel-díjat Shapley. A hozzárendelési játékot tekinthetjük valamilyen értelemben olyan házaspárosítási játéknak, ahol a felek pénzzel „kompenzálhatják egymást". Házaspárosításoknál általában a magot szokták vizsgálni, és a mag elemeit szokták stabil párosításoknak hívni, mivel ezeket a párosításokat nem érdeke senkinek felborítani. Mi ezzel szemben maradtunk a TU játékoknál bevezetett terminológiánál, és a nem dominált párosítások halmazát magnak fogjuk hívni, stabil halmaznak pedig a Neumann-Morgenstern értelemben stabil halmazokat.

Ehlers (2007) karakterizációjában hasonló tulajdonságok vannak, mint amilyeneket mi is használtunk a korábbiakban, ám mint látni fogjuk ilyen formában nem lesz igaz a hozzárendelési játékok esetében. A karakterizáció a következőket mondta ki:

2.1.1. Tétel (Ehlers (2007)). Házaspárositások esetén minden stabil halmaz

1. tartalmazza a játék magját

2. háló

3. bármely két elemében pontosan ugyanazok a játékosok vannak párosítva.

Továbbá erre a három tulajdonságra nézve maximális. 
És a fordított irány: abban az esetben ha csak egyetlen ilyen halmaz van, akkor az stabil.

Ehlers mutat példát is arra, hogy van olyan eset, amikor több halmaz is maximális erre a három tulajdonságra, de van köztük olyan, amelyik nem stabil.

Nézzük meg, működik-e ugyanez hozzárendelési játékokra! Az első tulajdonság, hogy tartalmazza a játék magját, általánosabban is igaz bármely játékra. A második tulajdonságot láttuk hozzárendelési játékokra az 1.3.4. állításban. A harmadik tulajdonsággal azonban van egy kis probléma, TU esetben nem világos, minek felel meg, hogy ugyanazok vannak párosítva. Hasonló tulajdonság lehet, hogy valamelyik principal sectionnek részhalmaza (mindig ugyanazok a párok osztoznak csak egymás közt az általuk elérhető mennyiségen. Esetleg egy kicsit megengedőbb változat, miszerint csak olyan játékos kifizetése lehet pozitív, aki valamelyik magelemben pozitív mennyiséget kap, azaz mindig ugyanazok osztoznak egymás közt, de itt már azt is megengedjük, hogy akár egy játékos kapjon mindent. Könnyen látható, hogy ezek közül egyik sem lesz jó, mert az egész principal sectionre mindkét esetben teljesül mindhárom tulajdonság, de az csak diagonális mátrix esetén lesz belső stabil.

Ehlers karakterizációja nem válaszol arra a kérdésre, hogy házaspárosításoknál egyáltalán létezik-e mindig stabil halmaz. Ezt a kérdést Wako (2010) válaszolta meg. Megmutatta, hogy mindig létezik stabil halmaz, ráadásul egyetlen stabil halmaz van. Láthatjuk, hogy ez egy lényeges különbség a két játékosztály között, mivel ahogy a 7. példában láttuk hozzárendelési játékoknál lehet több stabil halmaz is. Wako ötlete elég természetes. Keressünk egy stabil halmazt! Azt tudjuk, hogy tartalmazza a játék magját. Az össze párosítás közül kidobhatjuk azokat, amelyeket dominál a mag, mert azok biztos nem lesznek a stabil halmazban a belső stabilitása miatt. A külső stabilitás miatt, a stabil halmaz biztosan tartalmazza ennek a kisebb halmaznak a magját. Most megint kidobhatjuk azokat a párosításokat, amiket ez a nagyobb halmaz dominál...

A stabil halmaz készítésénél egyszerre két irányból haladunk, van egy egyre bővülő halmaz, amely biztos részhalmaza a stabil halmaznak, és egy szúkülö, amely tartalmazza a stabil halmazt. Wakonak sikerült megmutatnia hogy ez a két halmaz egy idő után összeér, mindkét irányból ugyanahhoz a halmazhoz jutunk, ami éppen ezért az egyetlen stabil halmaz.

Sajnos azonban hozzárendelési játékok esetében ez az ötlet sem múködik, mert a szúkülő halmaz tartalmazza a stabil halmazok unióját, a táguló pedig része a stabil halmazok metszetének, így ha több stabil halmaz is van, akkor a két irány nem fog összeérni.

Térjünk vissza a hozzárendelési játékokhoz! 
Innentől ha azt mondjuk, hogy egy vektor két másik között van, az azt fogja jelenteni, hogy minden egyes koordinátája a másik két vektor megfelelő koordinátái között van nem feltétlen szigorúan. Kicsit másképpen az $\boldsymbol{x}$ vektor az $\boldsymbol{y}$ és $\boldsymbol{z}$ között van, ha $\boldsymbol{x}=\operatorname{med}(\boldsymbol{x} ; \boldsymbol{y} ; \boldsymbol{z})$, ahol az eddigiekhez hasonlóan med a koordinátánkénti mediánt jelöli. Egy halmaznak két pont közti részén pedig a halmaz azon pontjait értjük, amelyek a két pont között vannak. Most, hogy ezen túl vagyunk kimondhatjuk a fejezet és talán az egész dolgozat legfontosabb eredményét.

2.1.2. Tétel. Bármely hozzárendelési játékban egy $\mathcal{V} \subseteq \mathcal{I}$ halmaz pontosan akkor stabil, ha

1. belső stabil,

2. összefüggö,

3. tartalmaz egy olyan elosztást, amelyben mindent az eladók és egy olyat, amelyben mindent a vevők kapnak,

4. tartalmazza bármely két pontja közti félelosztások magját.

Ezek közül az első három, amelyből természetesen a második és a harmadik érdekes szükségességét Shapley (1959) az itt következő bizonyításhoz nagyon hasonlóan belátta a hozzárendelési játékok egy speciális osztályára, a kesztyűjátékokra. Ezek olyan hozzárendelési játékok, amelyeket generáló (nem feltétlen négyzetes) mátrix minden eleme 1. Elégséges feltételt is adott egy halmaz stabilitására, de egyszerre szükséges és elégséges feltételt nem.

A negyedik tulajdonság hasonló az előző alfejezetben megadott $\mathcal{C B}$ halmaz definíciójához. Azt mondja ki, hogy ha $\left(\boldsymbol{x}^{1} ; \boldsymbol{y}^{1}\right)$ és $\left(\boldsymbol{x}^{2} ; \boldsymbol{y}^{2}\right)$ eleme $\mathcal{V}$-nek, és veszünk egy $\left(\boldsymbol{x}^{3} ; \boldsymbol{y}^{3}\right)$ félelosztást, amely ezen kettő közt van, és minden $(i ; j)$ vegyespárosra teljesül az $x_{i}^{3}=x_{i}^{1} \vee x_{i}^{2}$ vagy az $y_{j}^{3}=y_{j}^{1} \vee y_{j}^{2}$ vagy az $x_{i}^{3}+y_{j}^{3} \geq a_{i j}$ egyenlőtlenség, akkor $\left(\boldsymbol{x}^{3} ; \boldsymbol{y}^{3}\right)$ szintén eleme a $\mathcal{V}$ halmaznak. A definícióban fontos, hogy a FÉLelosztások magja szerepel, és nem elosztásoké. a 2.1.8. megjegyzésben láthatunk is példát arra, hogy ha a félelosztás szót elosztásra cserélnénk már nem biztos, hogy stabil lenne $\mathcal{V}$. Azért van szükségünk a félelosztásokra, mert ha az1.4.1. tételhez hasonlóan szeretnénk belátni az állítást, akkor abba a problémába ütközünk, hogy két elosztás hálókombinációja nem biztos hogy elosztás lesz. Ugyanez nyilván a félelosztásokra sem igaz, de két félelosztásnak az egyik hálókombinációja félelosztás lesz, így ha jól választunk hálókombinációt, az nem vezet ki a félelosztás halmazból. Ebben a negyedik feltételben elrejtve szerepel, 
hogy a halmaz két pontja közti félelosztások magja csak elosztásvektorokat tartalmazhat, szigorú félelosztásokat nem, mivel ha lenne benne szigorú félelosztás is, annak is $\mathcal{V}$-ben kellene lennie, viszont a tétel elején kikötöttük, hogy $\mathcal{V} \subseteq \mathcal{I}$.

Ez a tulajdonság az újdonság. Shapley (1959) cikkében a négy közül ez nem jelenik meg. Az újdonság benne az, hogy át kell térni a félelosztásokra. A stabilitásnak a tétel ismeretében nyilván szükséges feltétele az is, ha a negyedik tulajdonságot félelosztások helyett elosztásokkal mondjuk ki. Ez ilyen formában lényegében szerepel is Shapley (1959)-nél, nem mondja ki, mert ha szükséges feltételnek „nem túl szép”, a jelentőségét akkor nyeri el, amikor a fél szócska bekerülésével elégséges is lesz.

Shapley (1959) eredményére visszatérve, megmutatta, hogy kesztyűjátékok esetén minden stabil halmaz egy olyan koordinátánként monoton görbe, amelynek az egyik végpontjában az összes vevő-, a másikban az összes eladó kifizetése 0. Megmutatta továbbá, hogy ha ez a görbe olyan, hogy minden pontjában minden vegyespáros kifizetése legfeljebb 1, akkor ez a halmaz stabil. Mutatott továbbá példát stabil és nem stabil halmazra is, amikor a görbe kivezet az előbb említett halmazból.

Ha megnézzük ezek a feltételek hasonlítanak a 2.1.2. tételbeliekhez. A monotonitással lényegében megköveteli a belső stabilitást. Mivel a görbe egyik végén az összes vevö-, a másikon az összes eladó kifizetése 0 , ez azt jelenti, hogy ha az egyik irányba haladunk, akkor a vevők kifizetése monoton nő, az eladóké csökken. Ezért a görbének nem lehet olyan pontja ahol egy eladó-vevő páros mindkét tagja szigorúan jobban járna, mint egy másikban. Azzal, hogy a halmaznak egy görbének kell lennie, megköveteli az összefüggőséget. Itt jön ki a különbség a hozzárendelési játékok és a speciális esete, a kesztyưjátékok között. Kesztyüjátékoknál a stabil halmazok egyetlen görbéből állnak, míg ahogy az eddigi példákon is láttuk hozzárendelési játékokra ez általában ez nem igaz. Anélkül, hogy a részletekbe nagyon belemennénk elmondjuk ennek az okát. Kesztyưjátékokban minden teljes párosítás maximális értékü, ezért minden egyes pontban nagyon sok koalíció képes dominálni. Nagyon hasonló a 7 . példához, ahol két maximális értékủ párosítás is volt. Ott ha az egyik vegyespáros nem tud dominálni, mert többet kapnak az értéküknél, akkor a másik viszont tud. Ilyen játékoknál, ha veszünk egy elosztásvektort, akkor az a ritka, ha az valamelyik irányba nem képes dominálni. Azt láttuk az eddigi példákban is, hogy hozzárendelési játékokban általában már a mag sem csak egyetlen görbéből áll. Ennek ellenére lesz szerepe az ilyen monoton görbéknek, amelyeknek egyik végén mindent az eladók a másikon mindent a vevők kapnak. a 2.2.4 állításban a karakterizáció következményeként meg fogjuk mutatni, hogy egy ilyen görbe már meghatároza a stabil halmazt.

Látszólag az, hogy Shapley (1959) kesztyüjátékokkal foglalkozott az általánosabb 
eset helyett, elég nagy egyszerüsítés. Meglepő, de nem az. A bizonyítás nagyjából ugyanolyan nehéz mindkét esetben. 2.1.2. tétel bizonyításához először megmutatjuk, hogy a négy feltétel szükségességét, majd belátjuk, hogy elégségesek is. A szükségesség bizonyításakor lényegében pontosan követjük Shapley (1959) bizonyítását. A minimális különbség, hogy Shapley nem mondta ki a háló tulajdonságot, mert nem volt számára érdekes. Ugyanis abból hogy a halmaz egy monoton görbe triviálisan következik, hogy háló. az 1.3.2. állításnak egy változatát viszont ugyanúgy használta, mint mi itt.

Az elégségesség, ami a bizonyításnak a túlnyomó része viszont teljesen saját eredmény.

Az első tulajdonság (a belső stabilitás) benne van a stabil halmaz definíciójában.

Most megmutatjuk a harmadik tulajdonságot: Legyen $\mathcal{V}$ egy stabil halmaz az $A$ mátrixhoz tartozó hozzárendelési játékban. az 1.3.4. állításban beláttuk, $\mathcal{V}$ háló. Mivel tudjuk még, hogy minden stabil halmaz korlátos és zárt, így létezik $\mathcal{V}$-nek $(\underline{\boldsymbol{x}} ; \overline{\boldsymbol{y}})$ az eladók számára minimális, vevők számára maximális eleme. Ha $\underline{\boldsymbol{x}}$ vektornak lenne pozitív eleme, akkor a $(\mathbf{0} ; \overline{\boldsymbol{y}})$ szigorú félelosztást nem dominálná $\mathcal{V}$, ami ellentmond a halmaz külső stabilitásának. Itt használtuk az 1.1.9. állítást, miszerint egy halmaz pontosan akkor stabil, ha $\mathcal{I}^{\prime}$-stabil. Megmutattuk tehát, hogy van $\mathcal{V}$-nek olyan eleme, ahol mindent a vevők kapnak. Szimmetria miatt hasonlóan kaphatjuk, meg azt az elemét, amiben mindent az eladók kapnak. Ezzel sikerült megmutatni a 3. tulajdonságot

A maradék két tulajdonság az alábbi lemma következménye:

2.1.1. Lemma. Legyen $\left(\boldsymbol{x}^{1} ; \boldsymbol{y}^{1}\right) ;\left(\boldsymbol{x}^{2} ; \boldsymbol{y}^{2}\right) \in \mathcal{X}\left(\subseteq \mathcal{I}^{\prime}\right)$ belső stabil hálónak, és vegyünk egy $(\boldsymbol{u} ; \boldsymbol{v}) \notin \mathcal{X}$ vektort, amely az $\left(\boldsymbol{x}^{1} ; \boldsymbol{y}^{1}\right)$ és az $\left(\boldsymbol{x}^{2} ; \boldsymbol{y}^{2}\right)$ vektorok között van. Ekkor, ha van $\mathcal{X}$-nek olyan eleme, amely dominálja $(\boldsymbol{u} ; \boldsymbol{v})$-t, akkor $\left(\boldsymbol{x}^{1} ; \boldsymbol{y}^{1}\right)$ és $\left(\boldsymbol{x}^{2} ; \boldsymbol{y}^{2}\right)$ között is található ilyen eleme.

BIZONYÍTÁS.

Legyen $\left(\boldsymbol{x}^{3} ; \boldsymbol{y}^{3}\right)$ az az eleme $\mathcal{X}$-nek amely dominálja $(\boldsymbol{u} ; \boldsymbol{v})$-t az $(i ; j)$ vegyespároson keresztül. Szimmetria miatt feltehető, hogy $x_{i}^{1} \leq u_{i}$. Ebben az esetben $y_{j}^{1} \geq y_{j}^{3}$ kell, hogy teljesüljön ellenkező esetben $\left(\boldsymbol{x}^{3} ; \boldsymbol{y}^{3}\right)$ dominálná $\left(\boldsymbol{x}^{1} ; \boldsymbol{y}^{1}\right)$-et, ami ellentmondana $\mathcal{X}$ belső stabilitásának. Ekkor viszont $y_{j}^{1} \geq y_{j}^{3}>v_{j} \geq y_{j}^{2}$ egyenlőtlenségeknek is teljesülniük kell, mivel $\left(\boldsymbol{x}^{3} ; \boldsymbol{y}^{3}\right)$ dominálja $(\boldsymbol{u} ; \boldsymbol{v})$-t, ami $\left(\boldsymbol{x}^{1} ; \boldsymbol{y}^{1}\right)$ és $\left(\boldsymbol{x}^{2} ; \boldsymbol{y}^{2}\right)$ közt van. Az előzőekhez hasonlóan ekkor $x_{i}^{2} \geq x_{i}^{3}$ teljesül, mert ellenkező esetben $\left(\boldsymbol{x}^{3} ; \boldsymbol{y}^{3}\right)$ dominálná $\left(\boldsymbol{x}^{2} ; \boldsymbol{y}^{2}\right)$-t. Ekkor viszont teljesülnek az $x_{i}^{2} \geq x_{i}^{3}>u_{i} \geq x_{i}^{1}$ egyenlötlenségek is.

Legyen $\left(\boldsymbol{x}^{4} ; \boldsymbol{y}^{4}\right)=\operatorname{med}\left(\left(\boldsymbol{x}^{1} ; \boldsymbol{y}^{1}\right) ;\left(\boldsymbol{x}^{3} ; \boldsymbol{y}^{3}\right) ;\left(\boldsymbol{x}^{2} ; \boldsymbol{y}^{2}\right)\right)$. Mivel $x_{i}^{3}=x_{i}^{4}$ és $y_{j}^{3}=y_{j}^{4}$, ezért $\left(\boldsymbol{x}^{4} ; \boldsymbol{y}^{4}\right)$ is dominálja $(\boldsymbol{u} ; \boldsymbol{v})$-t az $(i ; j)$ vegyespároson keresztül. $\left(\boldsymbol{x}^{4} ; \boldsymbol{y}^{4}\right)$-ről az 1.3 .5 . állítás miatt tudjuk, hogy eleme $\mathcal{X}$-nek, amivel beláttuk a lemmát. 
A negyedik tulajdonságot innen már nagyon egyszerüen megkaphatjuk.

Ha $\left(\boldsymbol{x}^{1} ; \boldsymbol{y}^{1}\right),\left(\boldsymbol{x}^{2} ; \boldsymbol{y}^{2}\right) \in \mathcal{V}$, az $(\boldsymbol{u} ; \boldsymbol{v})$ vektor ezen két elem közti félelosztások magjában van, de nincs benne a stabil halmazban, akkor a külső stabilitás miatt van olyan eleme $\mathcal{V}$-nek, amely dominálja. Ekkor viszont $\left(\boldsymbol{x}^{1} ; \boldsymbol{y}^{1}\right)$ és $\left(\boldsymbol{x}^{2} ; \boldsymbol{y}^{2}\right)$ között is van ilyen eleme $\mathcal{V}$ nek, ami viszont nem lehetséges, mert $(\boldsymbol{u} ; \boldsymbol{v})$-t a két halmaz közti félelosztások magjából választottuk.

Az összefüggőség bizonyítása van csak hátra. a 2.1.1. lemma segítségével könnyen megmutatható, hogy $\mathcal{V}$ bármely két pontja közt van egy harmadik (az előző kettőtől különböző) pontja. Vegyük két elemét $\mathcal{V}$-nek, majd vegyük ezen két vektor átlagát. Ha az átlag is eleme $\mathcal{V}$-nek akkor kész vagyunk. Ha nem eleme az átlag, akkor a külső stabilitás miatt van olyan eleme $\mathcal{V}$-nek, amely dominálja. Ekkor a 2.1.1. lemma miatt az eredeti két vektor közt is van ilyen eleme $\mathcal{V}$-nek. Ez az elem nem egyezhet meg egyik eredeti vektorral sem, mert ez nem csak az átlagot, hanem a másik elemet is dominálná.

Innen a következő lemma segítségével kapjuk meg $\mathcal{V}$ összefüggöségét:

2.1.2. Lemma. Legyen $\mathcal{X} \subseteq \mathbb{R}^{n}$ egy olyan zárt halmaz, amelynek bármely két pontja közt van egy harmadik. Ekkor $\mathcal{X}$ bármely két $\boldsymbol{x}$ és $\boldsymbol{y}$ pontját összeköti koordinátánként monoton $\mathcal{X}$-beli görbe.

\section{BIZONYÍTÁS.}

Definiáljunk a $\mathcal{X}$ halmaz $\boldsymbol{x}$ és $\boldsymbol{y}$ pont közti részén egy részbenrendezést a következőképpen: $\boldsymbol{v} \succeq \boldsymbol{u}$ ha $\operatorname{med}(\boldsymbol{u} ; \boldsymbol{v} ; \boldsymbol{y})=\boldsymbol{v}$, azaz ha a $\boldsymbol{v}$ vektor $\boldsymbol{u}$-tól $\boldsymbol{y}$ felé van. Ebből a részbenrendezésből a kiválasztási axióma miatt kiválasztható egy $\mathcal{Y} \subseteq \mathcal{X}$ maximális, teljesen rendezett részhalmaz. $\mathcal{Y}$ nyilvánvalóan tartalmazza $\boldsymbol{x}$-et és $\boldsymbol{y}$-t, zárt (mivel $\mathcal{X}$ is zárt, így minden $\mathcal{Y}$-beli sorozathoz hozzávehetjük a határértékét is) és monoton, így biztos, hogy egy (nem feltétlen $\mathcal{X}$-beli) $\boldsymbol{x}$-et és $\boldsymbol{y}$-t összekötő monoton görbe zárt részhalmaza. Ha nem az egész görbe része $\mathcal{X}$-nek, az $\mathcal{Y}$ zártsága miatt csak úgy lehet, ha van két olyan pontja, ami közt nincs harmadik. Viszont tudjuk, hogy $\mathcal{X}$-nek van egy harmadik $\boldsymbol{z}$ pontja ezek között. $\mathcal{Y} \cup \boldsymbol{z} \subseteq \mathcal{X}$ egy teljesen rendezett részhalmaza $\mathcal{X}$-nek, ami ellentmond $\mathcal{Y}$ maximalitásának. Azt kaptuk tehát, hogy $\mathcal{Y} \subseteq \mathcal{X}$ egy $\boldsymbol{x}$-et és $\boldsymbol{y}$-t összekötő monoton görbe.

A 2.1.2. tételben szereplő tulajdonságok szükségességét most mutattuk meg, a következőkben megmutatjuk az elégségességét is. Innentől a bizonyítás végéig $\mathcal{V} \subseteq \mathcal{I}$ legyen egy olyan halmaz, ami teljesíti a 2.1.2. tételben szereplő négy tulajdonságot. Először megmutatjuk, hogy $\mathcal{V}$ háló.

2.1.3. Lemma. $\mathcal{V}$ halmaz egy háló. 


\section{BIZONYÍTÁs.}

Legyen $\left(\boldsymbol{x}^{1} ; \boldsymbol{y}^{1}\right),\left(\boldsymbol{x}^{2} ; \boldsymbol{y}^{2}\right) \in \mathcal{V}$. Az $\left(\boldsymbol{x}^{1} \vee \boldsymbol{x}^{2} ; \boldsymbol{y}^{1} \wedge \boldsymbol{y}^{2}\right)$ és $\left(\boldsymbol{x}^{1} \wedge \boldsymbol{x}^{2} ; \boldsymbol{y}^{1} \vee \boldsymbol{y}^{2}\right)$ vektorokat nem dominálja semmi az $\left(\boldsymbol{x}^{1} ; \boldsymbol{y}^{1}\right)$ és $\left(\boldsymbol{x}^{2} ; \boldsymbol{y}^{2}\right)$ vektorok közt, mivel az elsőnél az eladók a másodiknál a vevők nem kaphatnak többet. Ebből következik, hogy ha ezek elosztások, akkor a 4. feltétel miatt ezek is elemei $\mathcal{V}$-nek. Ha ezek valamelyike nem elosztás, akkor biztos, hogy a másik szigorú félelosztás. Ez a 4 . feltétel miatt eleme kell, hogy legyen $\mathcal{V}$ nek, viszont $\mathcal{V}$-ről feltettük, hogy az elosztáshalmaz részhalmaza, amivel ellentmondásra jutottunk.

Mivel $\mathcal{V}$ egy összefüggő háló, így az 1.3.7. állítás miatt bármely két pontját összeköti koordinátánként monoton görbe. Ennek a monotonitásnak a 2 dimenziós következménye a következö lemma:

2.1.4. Lemma. Legyen $\left(\boldsymbol{x}^{1} ; \boldsymbol{y}^{1}\right) ;\left(\boldsymbol{x}^{2} ; \boldsymbol{y}^{2}\right) \in \mathcal{V}$ amelyekre $x_{i}^{1} \geq x_{i}^{2}$ és $y_{j}^{1} \geq y_{j}^{2}$, ekkor $\forall x \in\left[x_{i}^{2} ; x_{i}^{1}\right], y \in\left[y_{j}^{2} ; y_{j}^{1}\right] \exists(\boldsymbol{x} ; \boldsymbol{y}) \in \mathcal{V}$, amelyre $x_{i}=x$ és $y_{j}=y$

Azaz ha vesszük két tetszőleges $\left(\boldsymbol{x}^{1} ; \boldsymbol{y}^{1}\right),\left(\boldsymbol{x}^{2} ; \boldsymbol{y}^{2}\right)$ elemét $\mathcal{V}$-nek és egy vegyespárost, amelynek mindkét tagja jobban jár $\left(\boldsymbol{x}^{1} ; \boldsymbol{y}^{1}\right)$-vel mint $\left(\boldsymbol{x}^{2} ; \boldsymbol{y}^{2}\right)$-vel, akkor ha $\mathcal{V}$-t megszorítjuk ennek a két játékosnak a kifizetésére, az így kapott halmaz tartalmazza a két pont által kifeszített téglalapot.

BIZONYÍTÁs.

a 2.1.3. lemma miatt $\left(\boldsymbol{x}^{1} \wedge \boldsymbol{x}^{2} ; \boldsymbol{y}^{1} \vee \boldsymbol{y}^{2}\right)$ és $\left(\boldsymbol{x}^{1} \vee \boldsymbol{x}^{2} ; \boldsymbol{y}^{1} \wedge \boldsymbol{y}^{2}\right)$ eleme $\mathcal{V}$-nek. az 1.3.7. álítás miatt létezik $\left(\boldsymbol{x}^{1} ; \boldsymbol{y}^{1}\right)$-et és $\left(\boldsymbol{x}^{1} \wedge \boldsymbol{x}^{2} ; \boldsymbol{y}^{1} \vee \boldsymbol{y}^{2}\right)$-t valamint $\left(\boldsymbol{x}^{2} ; \boldsymbol{y}^{2}\right)$-t és $\left(\boldsymbol{x}^{1} \vee \boldsymbol{x}^{2} ; \boldsymbol{y}^{1} \wedge \boldsymbol{y}^{2}\right)$-t összekötö koordinátánként monoton $\mathcal{V}$-beli görbe. Mindkét görbének van olyan pontja, amelyen az $i$. eladó kifizetése éppen $x$. Az első görbén ekkor a $j$. vevő kifizetése $y_{j}^{1}$, a másodikon $y_{j}^{2}$. Ezt a két görbét is köti össze monoton $\mathcal{V}$-beli görbe, aminek van olyan pontja, amelyben a $j$. vevő kifizetése pontosan $y$, ami pont az, amit kerestünk.

Az előző lemma segítségével egy, a belső stabilitásnál erősebb tulajdonságot is tudunk mondani $\mathcal{V}$-röl:

2.1.5. Következmény. Legyen $\left(\boldsymbol{x}^{1} ; \boldsymbol{y}^{1}\right) ;\left(\boldsymbol{x}^{2} ; \boldsymbol{y}^{2}\right) \in \mathcal{V}$ amelyekre $x_{i}^{1}>x_{i}^{2}$ és $y_{j}^{1}>y_{j}^{2}$, ekkor $x_{i}^{2}+y_{j}^{2} \geq a_{i j}$. (A belsö stabilitás csak az $x_{i}^{1}+y_{j}^{1}>a_{i j}$ egyenlötlenséget követeli meg)

BIZONYÍTÁS.

Tegyük fel, hogy ez nem igaz és $x_{i}^{2}+y_{j}^{2} \geq a_{i j}$. Legyen $\epsilon<\min \left(\frac{a_{i j}-x_{i}^{2}-y_{j}^{2}}{2} ; x_{i}^{1}-x_{i}^{2} ; y_{j}^{1}-y_{j}^{2}\right)$ pozitív szám. Ekkor 2.1.4. lemma miatt van olyan $(\boldsymbol{x} ; \boldsymbol{y}) \in \mathcal{V}$, amelyre $x_{i}=x_{i}^{2}+\epsilon$ és $y_{j}=y_{j}^{2}+\epsilon$. Ez az $(\boldsymbol{x} ; \boldsymbol{y})$ elosztás viszont dominálja $\left(\boldsymbol{x}^{2} ; \boldsymbol{y}^{2}\right)$-t az $(i ; j)$ vegyespároson keresztül, ami ellentmond $\mathcal{V}$ belső stabilitásának. 
Ez a következmény azt mondja ki, hogy ha vesszük tetszőleges két elemét $\mathcal{V}$-nek és egy vegyespárost, amelynek mindkét tagja jobban jár az első vektorral, mint a másodikkal, akkor nem elég, hogy az első vektor ne tudjon dominálni, az is kell, hogy a másodikat ne lehessen. Elvileg ez könnyen elképzelhető lenne. Például ha az első vektorban a vegyespáros kifizetése 6 illetve 3 egység, a másikban mindkét játékos kifizetése 2, a vegyespáros értéke pedig 6. Ez még önmagában nem sértené a belső stabilitást, mivel a kedvezőbb vektor nem elérhető a vegyespáros számára, így nem képes dominálni sem. a 2.1.4. lemma miatt viszont ebből következik, hogy $\mathcal{V}$-nek van egy olyan eleme is, amelyben a vegyespáros mindkét tagja 3-at kap, ami már dominálja a számukra rosszabbik vektort ellentmondva a belső stabilitásnak. Ez látható a 13 , ábrán. Az eddigiekhez hasonlóan az $i$. eladó kifizetését balról jobbra, a $j$. vevőét felülről lefelé ábrázoltuk. A principal sectionnel ellentétben most már nem igaz, hogy ilyenkor az $i$. vevő és $j$. eladó kifizetése pont az ellenkező irányba nőne, most csak ennek a két játékosnak a kifizetését tudjuk leolvasni az ábráról. A bal alsó sarokban szerepel az, ahol mindent a vevők jobb felsőben, ahol mindent az eladók kapnak. A pontozott vonalon aktív az $(i ; j)$ vegyespáros, azaz ezen egyenes mentén kapnak együtt pont annyit, amennyi az értékük. Ezen vonal, valamint a tőle balra felfelé található félsík pontjai dominálják, a maguktól balra felfelé lévő síknegyedet. Önmagában az, hogy $\left(\boldsymbol{x}^{1} ; \boldsymbol{y}^{1}\right)$ és $\left(\boldsymbol{x}^{2} ; \boldsymbol{y}^{2}\right)$ is része egy stabil halmaznak, még nem lenne probléma. $\left(\boldsymbol{x}^{1} ; \boldsymbol{y}^{1}\right)$ nem dominálja $\left(\boldsymbol{x}^{2} ; \boldsymbol{y}^{2}\right)$-t, mert a pontozott vonal alatt van. Önmagában az összefüggöség sem vezetne problémához, mert meg tudnánk oldani, hogy $\left(\boldsymbol{x}^{1} ; \boldsymbol{y}^{1}\right)$-et a vevő- és eladóoptimális pontokkal a pontozott vonal alatt kössük össze. Viszont 2.1.3. miatt a stabil halmazban benne kell lennie az $\left(\boldsymbol{x}^{1} ; \boldsymbol{y}^{1}\right)$ és $\left(\boldsymbol{x}^{2} ; \boldsymbol{y}^{2}\right)$ két hálókombinációjának is, ez látható a 13 ábrán. az 1.3.7. állítást egyszer felhasználva tudjuk, hogy a stabil halmaz bármely két pontját összeköti koordinátánként monoton görbe, ezért a stabil halmaz vetülete tartalmazza az $\left(\boldsymbol{x}^{1} ; \boldsymbol{y}^{1}\right),\left(\boldsymbol{x}^{2} ; \boldsymbol{y}^{2}\right)$, valamint hálókombinációik által meghatározott téglalap körvonalát. Majd a körvonal pontjaira használva az 1.3.7. állítást, a vetület tartalmazza a téglalap belsejét is. Ez viszont már baj, mert a téglalap belsejének már van pontja a pontozott vonalon, amely dominálja $\left(\boldsymbol{x}^{2} ; \boldsymbol{y}^{2}\right)$-t. Geometriailag az ábránkon a 2.1.5. következmény azt mondja ki, hogy ha van két pont úgy, hogy az egyik a másiktól szigorúan balra felfelé van, akkor mindkettőnek a pontozott vonal alatti zárt féltérben kell lennie. A belső stabilitás csak azt követelte meg, hogy az egyik legyen az alsó nyílt féltérben.

$\mathcal{V}$-ről a 2.1.3. lemmában megmutattuk, hogy háló. A következő lemmában megmutatjuk, hogy a 3. feltételben megadott pontok ennek a hálónak az eladó- illetve vevőoptimális pontjai. Ez azért is fontos, mert $\mathcal{V}$-röl még nem tudjuk, hogy zárt halmaz, így akár az is elképzelhető lenne, hogy nincsenek is ilyen pontjai. 


\section{3. ábra. Erősebb belső stabilitás}

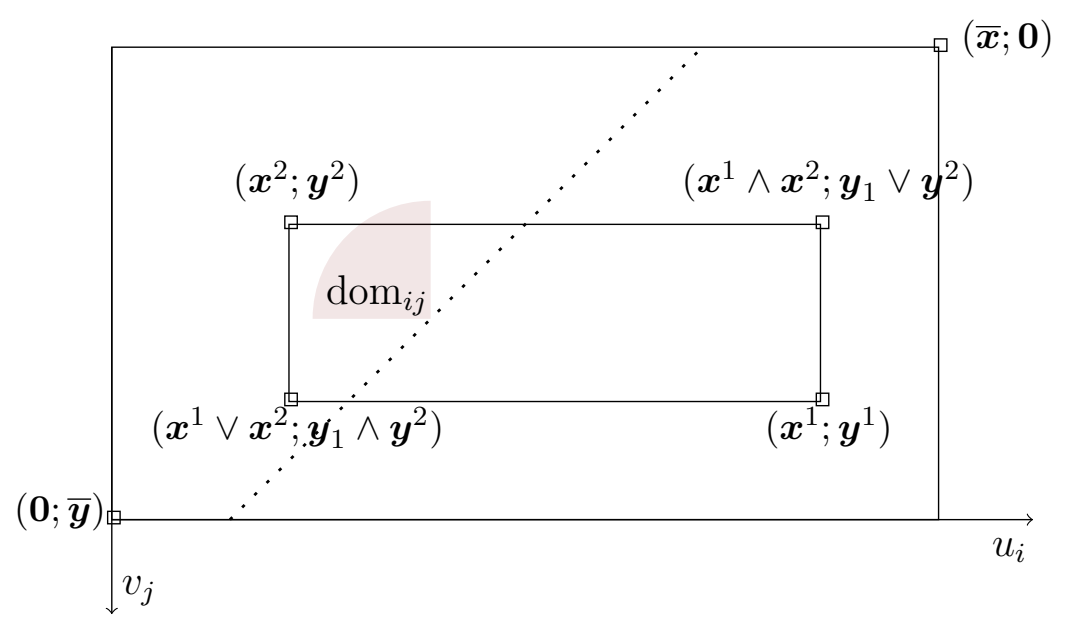

2.1.6. Lemma. $\mathcal{V}$ halmaz az $(\overline{\boldsymbol{x}} ; \mathbf{0})$ és $(\mathbf{0} ; \overline{\boldsymbol{y}})$ alakú pontjai között helyezkedik el.

\section{BIZONYÍTÁS.}

Tegyük fel, hogy nem így van és van olyan $(\boldsymbol{x} ; \boldsymbol{y}) \in \mathcal{V}$, amire $x_{i}>\bar{x}_{i}$ valamelyik eladóra (a $y_{j}>\bar{y}_{j}$ eset szimmetria miatt ugyanígy megy). Ekkor 2.1.3. lemma miatt $\mathcal{V}$ halmaz háló, így $(\boldsymbol{x} \vee \overline{\boldsymbol{x}} ; \boldsymbol{y} \wedge \mathbf{0})=(\boldsymbol{x} \vee \overline{\boldsymbol{x}} ; \mathbf{0}) \in \mathcal{V}$, de ez a vektor nem elosztás, mivel a koordinátáinak összege nagyobb mint $(\overline{\boldsymbol{x}} ; \mathbf{0})$-ban, ami ellentmond $\mathcal{V} \subseteq \mathcal{I}$-nek.

Innentől jön a bizonyítás nehezebb része.

\subsubsection{Lemma. $\mathcal{V}$ zárt.}

BizONYÍTÁs.

Definiáljuk $\left(\boldsymbol{x}^{1} ; \boldsymbol{y}^{1}\right),\left(\boldsymbol{x}^{2} ; \boldsymbol{y}^{2}\right) \in \mathcal{V}$-re, és a kettő közt lévő $(\boldsymbol{u} ; \boldsymbol{v}) \notin \mathcal{V}$-re az $f$ függvényt a következőképpen: $f\left(\left(\boldsymbol{x}^{1} ; \boldsymbol{y}^{1}\right),(\boldsymbol{u} ; \boldsymbol{v}),\left(\boldsymbol{x}^{2} ; \boldsymbol{y}^{2}\right)\right)=\#\left\{(i ; j): u_{i}<x_{i}^{1} \vee x_{i}^{2}\right.$ és $v_{j}<y_{j}^{1} \vee$ $y_{j}^{2}$ és $\left.u_{i}+v_{j}<a_{i j}\right\}$ azaz azon vegyespárosok száma, amiken keresztül lehet dominálni $(\boldsymbol{u} ; \boldsymbol{v})$-t az $\left(\boldsymbol{x}^{1} ; \boldsymbol{y}^{1}\right)$ és $\left(\boldsymbol{x}^{2} ; \boldsymbol{y}^{2}\right)$ között. Ezzel a jelöléssel a 2.1.2. tételbeli negyedik feltétel pont azt mondja ki, hogy ha $(\boldsymbol{u} ; \boldsymbol{v})$ egy félelosztás és $f\left(\left(\boldsymbol{x}^{1} ; \boldsymbol{y}^{1}\right),(\boldsymbol{u} ; \boldsymbol{v}),\left(\boldsymbol{x}^{2} ; \boldsymbol{y}^{2}\right)\right)=0$, akkor $(\boldsymbol{u} ; \boldsymbol{v}) \in \mathcal{V}$.

Tegyük fel, hogy $\mathcal{V}$ nem zárt, azaz létezik olyan $\mathcal{V}$-beli $\left(\boldsymbol{u}^{k} ; \boldsymbol{v}^{k}\right)$ sorozat, aminek az $(\boldsymbol{u} ; \boldsymbol{v})$ határértéke $\mathcal{I} \backslash \mathcal{V}$-beli. a 2.1.6. lemma miatt ez a határérték is két $\mathcal{V}$-beli vektor közé esik. Válasszuk meg ezt a sorozatot és hozzá két $\left(\boldsymbol{x}^{1} ; \boldsymbol{y}^{1}\right),\left(\boldsymbol{x}^{2} ; \boldsymbol{y}^{2}\right) \in \mathcal{V}$-beli pontot úgy, hogy $(\boldsymbol{u} ; \boldsymbol{v}) \notin \mathcal{V}$ ezen két pont közé essen, és az ilyen hármasok közül az $f\left(\left(\boldsymbol{x}^{1} ; \boldsymbol{y}^{1}\right),(\boldsymbol{u} ; \boldsymbol{v}),\left(\boldsymbol{x}^{2} ; \boldsymbol{y}^{2}\right)\right)$ érték minimális legyen. Feltehetö, hogy $\boldsymbol{x}^{1} \leq \boldsymbol{u} \leq \boldsymbol{x}^{2}$ és $\boldsymbol{y}^{1} \geq \boldsymbol{v} \geq \boldsymbol{y}^{2}$, mivel $\left(\boldsymbol{x}^{1} ; \boldsymbol{y}^{1}\right)$ és $\left(\boldsymbol{x}^{2} ; \boldsymbol{y}^{2}\right)$ valamint $\left(\boldsymbol{x}^{1} \vee \boldsymbol{x}^{2} ; \boldsymbol{y}^{1} \wedge \boldsymbol{y}^{2}\right)$ és $\left(\boldsymbol{x}^{1} \wedge \boldsymbol{x}^{2} ; \boldsymbol{y}^{1} \vee\right.$ 
$\left.\boldsymbol{y}^{2}\right)$ ugyanazt a téglatestet határozzák meg és az utóbbi pontokra már teljesülnek az egyenlötlenségek. $f\left(\left(\boldsymbol{x}^{1} ; \boldsymbol{y}^{1}\right),(\boldsymbol{u} ; \boldsymbol{v}),\left(\boldsymbol{x}^{2} ; \boldsymbol{y}^{2}\right)\right)$ nem lehet 0 , mert akkor $(\boldsymbol{u} ; \boldsymbol{v})$-t nem dominálná semmi az $\left(\boldsymbol{x}^{1} ; \boldsymbol{y}^{1}\right)$ és $\left(\boldsymbol{x}^{2} ; \boldsymbol{y}^{2}\right)$ vektorok közt, így a 4 . tulajdonság miatt $(\boldsymbol{u} ; \boldsymbol{v}) \in \mathcal{V}$ teljesülne.

Ha $f\left(\left(\boldsymbol{x}^{1} ; \boldsymbol{y}^{1}\right),(\boldsymbol{u} ; \boldsymbol{v}),\left(\boldsymbol{x}^{2} ; \boldsymbol{y}^{2}\right)\right)$ nem 0 , akkor létezik olyan $(i ; j)$ vegyespáros, amely képes dominálni $(\boldsymbol{u} ; \boldsymbol{v})$-t az $\left(\boldsymbol{x}^{1} ; \boldsymbol{y}^{1}\right)$ és $\left(\boldsymbol{x}^{2} ; \boldsymbol{y}^{2}\right)$ pontok közötti vektorral, azaz $u_{i}<$ $x_{i}^{2} ; v_{j}<y_{j}^{1}$ és $u_{i}+v_{j}<a_{i j}$. Láttuk, hogy létezik $\left(\boldsymbol{x}^{1} ; \boldsymbol{y}^{1}\right)$-et és $\left(\boldsymbol{x}^{2} ; \boldsymbol{y}^{2}\right)$-t összekötő monoton $\mathcal{V}$-beli görbe. Vegyünk egy ilyen görbét és nézzük meg, hogy hol metszi el azt a hipersíkot, ahol az $i$. eladó és a $j$. vevő kifizetésének különbsége $u_{i}-v_{j}$. Legyen $\left(\boldsymbol{x}^{3} ; \boldsymbol{y}^{3}\right)$ egy ilyen pont.

Ha $x_{i}^{3} \neq u_{i}$ és $y_{j}^{3} \neq v_{j}$, akkor az ellentmond a 2.1.5. következménynek, mivel az $\left(\boldsymbol{u}^{k} ; \boldsymbol{v}^{k}\right) \subseteq \mathcal{V}$ sorozatnak van olyan eleme az $(\boldsymbol{u} ; \boldsymbol{v})$ ponthoz közel, amelyre $u_{i}^{k}+v_{j}^{k}<a_{i j}$ és az $(i ; j)$ vegyespáros mindkét tagja egyszerre vagy jobban vagy rosszabbul jár mint $\left(\boldsymbol{x}^{3} ; \boldsymbol{y}^{3}\right)$-ban.

Vegyük $\left(\boldsymbol{x}^{3} ; \boldsymbol{y}^{3}\right)$ és $(\boldsymbol{u} ; \boldsymbol{v})$-nek a $\left(\boldsymbol{x}^{3} \vee \boldsymbol{u} ; \boldsymbol{y}^{3} \wedge \boldsymbol{v}\right)$ hálókombinációját és ezt jelöljük $\left(\boldsymbol{x}^{4} ; \boldsymbol{y}^{4}\right)$-gyel. Erről tudjuk, hogy elosztás, mivel ez a $\left(\boldsymbol{x}^{3} \vee \boldsymbol{u}^{k} ; \boldsymbol{y}^{3} \wedge \boldsymbol{v}^{k}\right) \subseteq \mathcal{V}$ elosztásokból álló sorozat határértéke, és elosztások határértéke elosztás.

Két eset van.

1. $\left(\boldsymbol{x}^{4} ; \boldsymbol{y}^{4}\right) \in \mathcal{V}$ : ebben az esetben könnyen ellentmondásra jutunk, mivel ha az $\left(\boldsymbol{x}^{2} ; \boldsymbol{y}^{2}\right)$ vektor helyett vesszük $\left(\boldsymbol{x}^{4} ; \boldsymbol{y}^{4}\right)$-et, akkor $f\left(\left(\boldsymbol{x}^{1} ; \boldsymbol{y}^{1}\right) ;(\boldsymbol{u} ; \boldsymbol{v}) ;\left(\boldsymbol{x}^{4} ; \boldsymbol{y}^{4}\right)\right)$ nem lehet nagyobb mint $f\left(\left(\boldsymbol{x}^{1} ; \boldsymbol{y}^{1}\right) ;(\boldsymbol{u} ; \boldsymbol{v}) ;\left(\boldsymbol{x}^{2} ; \boldsymbol{y}^{2}\right)\right)$, mivel az $\left(\boldsymbol{x}^{1} ; \boldsymbol{y}^{1}\right)$ és $\left(\boldsymbol{x}^{4} ; \boldsymbol{y}^{4}\right)$ által meghatározott tégla része az $\left(\boldsymbol{x}^{1} ; \boldsymbol{y}^{1}\right)$ és $\left(\boldsymbol{x}^{2} ; \boldsymbol{y}^{2}\right)$ által meghatározottnak, és szigorúan kisebb, mivel az $(i ; j)$ páros már nem tudja dominálni $(\boldsymbol{u} ; \boldsymbol{v})$-t, mert az $i$. eladó a maximumot kapja.

2. $\left(\boldsymbol{x}^{4} ; \boldsymbol{y}^{4}\right) \notin \mathcal{V}$ : ez az eset is hasonló. Ekkor sem volt minimális az $f$ függvény értéke, mivel ha $(\boldsymbol{u} ; \boldsymbol{v})$ helyett $\left(\boldsymbol{x}^{4} ; \boldsymbol{y}^{4}\right)\left(=\left(\boldsymbol{x}^{3} \vee \boldsymbol{u} ; \boldsymbol{y}^{3} \wedge \boldsymbol{v}\right)\right)$-t, $\left(\boldsymbol{x}^{1} ; \boldsymbol{y}^{1}\right)$ helyett $\left(\boldsymbol{x}^{3} ; \boldsymbol{y}^{3}\right)$-at, az $\left(\boldsymbol{u}^{k} ; \boldsymbol{v} ; k\right)$ sorozat helyett pedig a $\left(\boldsymbol{x}^{3} \vee \boldsymbol{u}^{k} ; \boldsymbol{y}^{3} \wedge \boldsymbol{v}^{k}\right)$ sorozatot választottuk volna, akkor kisebb értéket kapnánk. Ez a választás lehetséges, mivel $\left(\boldsymbol{x}^{4} ; \boldsymbol{y}^{4}\right) \notin \mathcal{V}$ és a $\left(\boldsymbol{x}^{3} \vee \boldsymbol{u}^{k} ; \boldsymbol{y}^{3} \wedge \boldsymbol{v}^{k}\right) \subseteq \mathcal{V}$ minden $k$-ra, a sorozat határértéke éppen $\left(\boldsymbol{x}^{4} ; \boldsymbol{y}^{4}\right)$, és $\left(\boldsymbol{x}^{4} ; \boldsymbol{y}^{4}\right)$ pedig a definíciója miatt az $\left(\boldsymbol{x}^{3} ; \boldsymbol{y}^{3}\right)$ és $\left(\boldsymbol{x}^{2} ; \boldsymbol{y}^{2}\right)$ pontok közt van. Könnyen látható, hogy $f\left(\left(\boldsymbol{x}^{1} ; \boldsymbol{y}^{1}\right),(\boldsymbol{u} ; \boldsymbol{v}),\left(\boldsymbol{x}^{2} ; \boldsymbol{y}^{2}\right)\right)>f\left(\left(\boldsymbol{x}^{3} ; \boldsymbol{y}^{3}\right),\left(\boldsymbol{x}^{4} ; \boldsymbol{y}^{4}\right),\left(\boldsymbol{x}^{2} ; \boldsymbol{y}^{2}\right)\right)$, mivel azok a játékosok akik $(\boldsymbol{u} ; \boldsymbol{v})$-ben az első esetben a maximumot kapják, azok $\left(\boldsymbol{x}^{4} ; \boldsymbol{y}^{4}\right)$-ben másodszorra is, és egy játékos kifizetése csak akkor csökkenhet, ha másodszorra a téglalapon belüli maximális értéket kapja. Amelyik páros tehát az első esetben nem tudott dominálni az a másodikban sem, viszont az $(i ; j)$ koalíció a második 
esetben nem tud dominálni, mert $y_{j}^{4}=y_{j}^{3}=y_{j}^{3} \vee y_{j}^{2}$ miatt a $j$. vevő a maximumot kapja.

A lemmák után következzen a 2.1.2. tételben szereplő feltételek elégségességének bizonyítása:

2.1.2. TÉTEL BIZONYÍTÁSA.

$\mathcal{V}$ stabilitását a zártságához hasonlóan bizonyítjuk. Megmutatjuk, hogy a $\mathcal{V}$ halmaz $\mathcal{I}^{\prime}$-stabil, ami mint az 1.1.9. állításban láttuk ekvivalens a stabilitással. $\mathcal{V}$ belső stabilitását az 1. tulajdonságban megköveteltük, így elég a külsőt megmutatni. Tegyük fel, hogy van olyan $(\boldsymbol{u} ; \boldsymbol{v}) \in \mathcal{I}^{\prime} \backslash \mathcal{V}$ vektor, amit nem dominál $\mathcal{V}$.

Feltehető, hogy $(\boldsymbol{u} ; \boldsymbol{v})$ vektor a $\mathcal{V}$ halmaz $(\overline{\boldsymbol{x}} ; \mathbf{0})$ és $(\mathbf{0} ; \overline{\boldsymbol{y}})$ alakú pontjai között van, mivel ha nem így lenne, akkor vegyük a $\operatorname{med}((\overline{\boldsymbol{x}} ; \mathbf{0}) ;(\boldsymbol{u} ; \boldsymbol{v}) ;(\mathbf{0} ; \overline{\boldsymbol{y}}))$ vektort. Ha ez nem egyezik meg $(\boldsymbol{u} ; \boldsymbol{v})$-vel, akkor a koordinátáinak összege szigorúan kisebb mint $(\boldsymbol{u} ; \boldsymbol{v})$-é, így $\mathcal{V} \subseteq \mathcal{I}$ miatt ez a vektor nincs $\mathcal{V}$-ben és 1.3.2, többszöri alkalmazása miatt elég megmutatnunk, hogy ezt a félelosztást dominálja egy $\mathcal{V}$-beli vektor, mert ebből már következik, hogy az az elosztás dominálja $(\boldsymbol{u} ; \boldsymbol{v})$-t is.

2.1.7. lemma bizonyításához hasonlóan most is vegyünk úgy $\left(\boldsymbol{x}^{1} ; \boldsymbol{y}^{1}\right) ;\left(\boldsymbol{x}^{2} ; \boldsymbol{y}^{2}\right) \in$ $\mathcal{V}$ és $(\boldsymbol{u} ; \boldsymbol{v}) \in \mathcal{I}^{\prime} \backslash \mathcal{V}$ pontokat, hogy fennálljanak az $\boldsymbol{x}^{1} \leq \boldsymbol{u} \leq \boldsymbol{x}^{2}$ és $\boldsymbol{y}^{1} \leq \boldsymbol{v} \leq$ $\boldsymbol{y}^{2}$ egyenlőtlenségek, $(\boldsymbol{u} ; \boldsymbol{v})$-t ne dominálja $\mathcal{V}$, és az ilyen pont hármasok közül az $f\left(\left(\boldsymbol{x}^{1} ; \boldsymbol{y}^{1}\right),(\boldsymbol{u} ; \boldsymbol{v}),\left(\boldsymbol{x}^{2} ; \boldsymbol{y}^{2}\right)\right)$ érték (hogy hány vegyespáros tudja dominálni $(\boldsymbol{u} ; \boldsymbol{v})$-t $\left(\boldsymbol{x}^{1} ; \boldsymbol{y}^{1}\right)$ és $\left(\boldsymbol{x}^{2} ; \boldsymbol{y}^{2}\right)$ közti vektorral) legyen minimális. Ez az érték most sem lehet 0 , mert az azt jelentené, hogy az $(\boldsymbol{u} ; \boldsymbol{v})$ félelosztást nem dominálná semmi az $\left(\boldsymbol{x}^{1} ; \boldsymbol{y}^{1}\right)$ és $\left(\boldsymbol{x}^{2} ; \boldsymbol{y}^{2}\right)$ elosztások közt, így a 4. tulajdonság miatt $(\boldsymbol{u} ; \boldsymbol{v}) \in \mathcal{V}$ lenne, ami ellentmond $(\boldsymbol{u} ; \boldsymbol{v})$ megválasztásának.

Tudjuk tehát, hogy létezik egy $(i ; j)$ vegyespáros amely képes dominálni $(\boldsymbol{u} ; \boldsymbol{v})$ t egy $\left(\boldsymbol{x}^{1} ; \boldsymbol{y}^{1}\right)$ és $\left(\boldsymbol{x}^{2} ; \boldsymbol{y}^{2}\right)$ közötti vetorral, azaz teljesülnek az $u_{i}<x_{i}^{2} ; v_{j}<y_{j}^{1}$ és $u_{i}+v_{j}<a_{i j}$ egyenlőtlenségek. a 2.1.7. lemma bizonyításához hasonlóan tudjuk, hogy mivel $\mathcal{V}$ egy összefüggö háló, az 1.3.7. lemma miatt létezik $\left(\boldsymbol{x}^{1} ; \boldsymbol{y}^{1}\right)$-et és $\left(\boldsymbol{x}^{2} ; \boldsymbol{y}^{2}\right)$-t összekötő, koordinátánként monoton $\mathcal{V}$-beli görbe. Vegyünk egy ilyen görbét, és nézzük meg, hogy hol metszi el azt a hipersíkot, ahol az $i$. eladó és a $j$. vevő kifizetésének különbsége éppen $u_{i}-v_{j}$. Legyen $\left(\boldsymbol{x}^{3} ; \boldsymbol{y}^{3}\right)$ egy ilyen pont. Innentől tér el a bizonyítás, mert most nem állíthatjuk, hogy $x_{i}^{3}=u_{i}$ és $y_{j}^{3}=v_{j}$. Két lehetőség van:

1. $x_{i}^{3} \leq u_{i}$ és $y_{j}^{3} \leq v_{j}$ : Tudjuk, hogy $\left(\boldsymbol{x}^{3} \vee \boldsymbol{u} ; \boldsymbol{y}^{3} \wedge \boldsymbol{v}\right)$ és $\left(\boldsymbol{x}^{3} \wedge \boldsymbol{u} ; \boldsymbol{y}^{3} \vee \boldsymbol{v}\right)$ közül legalább az egyik félelosztás. Szimmetria miatt feltehető, hogy ez az első, jelöljük ezt $\left(\boldsymbol{x}^{4} ; \boldsymbol{y}^{4}\right)$-gyel. 
- ha $\left(\boldsymbol{x}^{4} ; \boldsymbol{y}^{4}\right) \in \mathcal{V}$, akkor $\left(\boldsymbol{x}^{2} ; \boldsymbol{y}^{2}\right)$-t lecserélve $\left(\boldsymbol{x}^{4} ; \boldsymbol{y}^{4}\right)$-re az $f$ függvény értékét sikerült csökkenteni, mivel akik eddig maximumot kapták azok most is, és $(\boldsymbol{u} ; \boldsymbol{v})$ most is ugyanazokat a magegyenlötlenségeket szegi meg, viszont most már az $i$. vevő is a maximumot kapja, így az $(i ; j)$ koalíción keresztül sem lehet dominálni az $\left(\boldsymbol{x}^{1} ; \boldsymbol{y}^{1}\right)$ és $\left(\boldsymbol{x}^{4} ; \boldsymbol{y}^{4}\right)$ közti részen. Ez viszont ellentmond $\left(\boldsymbol{x}^{1} ; \boldsymbol{y}^{1}\right),(\boldsymbol{u} ; \boldsymbol{v})$ és $\left(\boldsymbol{x}^{2} ; \boldsymbol{y}^{2}\right)$ választásának.

- ha $\left(\boldsymbol{x}^{4} ; \boldsymbol{y}^{4}\right) \notin \mathcal{V}$, akkor $(\boldsymbol{u} ; \boldsymbol{v})$-t cseréljük le $\left(\boldsymbol{x}^{4} ; \boldsymbol{y}^{4}\right)$-re és $\left(\boldsymbol{x}^{1} ; \boldsymbol{y}^{1}\right)$-et $\left(\boldsymbol{x}^{3} ; \boldsymbol{y}^{3}\right)$ ra. Az $f$ függvény értéke itt is csökken, 2.1.7. lemma bizonyításához hasonlóan, mert akik eddig maximumot kaptak azok most is, és egy játékos csak akkor kaphat kevesebbet az új helyzetben, ha a maximális értéket kapja, amit $\left(\boldsymbol{x}^{3} ; \boldsymbol{y}^{3}\right)$ és $\left(\boldsymbol{x}^{2} ; \boldsymbol{y}^{2}\right)$ közt elérhet.

a 14 ábrán szemléltetjük ezt az esetet. Az $(i ; j)$ vegyespáros kifizetését ábrázoltuk, az $i$. eladó kifizetése balról jobbra nő, a $j$. vevő kifizetése felülről lefelé. Az 1 meredekségú pontozott vonal mentén kapja az $(i ; j)$ vegyespáros pontosan az értékét. A pontozott vonal, valamint a tőle balra felfelé lévő félsík pontjai képesek dominálni a tőlül balra felfelé lévő nyílt síknegyed pontjait az $(i ; j)$ vegyespároson keresztül. Az $(\boldsymbol{u} ; \boldsymbol{v})$ pont is efelett a pontozott vonal felett van, így van olyan pont $\left(\boldsymbol{x}^{1} ; \boldsymbol{y}^{1}\right)$ és $\left(\boldsymbol{x}^{2} ; \boldsymbol{y}^{2}\right)$ között ami dominálja. A zöld görbe az $\left(\boldsymbol{x}^{1} ; \boldsymbol{y}^{1}\right)$ és $\left(\boldsymbol{x}^{2} ; \boldsymbol{y}^{2}\right)$ elosztásokat összekötő $\mathcal{V}$-beli monoton görbe. $\left(\boldsymbol{x}^{3} ; \boldsymbol{y}^{3}\right)$ a görbének egy olyan pontja, ahol az $(\boldsymbol{u} ; \boldsymbol{v})$-ből kiinduló -1 meredekségü egyenes és a zöld görbe metszi egymást. Az 1. pont az az eset, amikor ez a metszéspont az $(\boldsymbol{u} ; \boldsymbol{v})$-től balra felfelé van, esetleg egybeesik vele (ha egybeesik, akkor csak ezen a vetületen). $\left(\boldsymbol{x}^{4} ; \boldsymbol{y}^{4}\right)$ az $(\boldsymbol{u} ; \boldsymbol{v})$ és $\left(\boldsymbol{x}^{3} ; \boldsymbol{y}^{3}\right)$ csúcsok hálókombinációja.

Ha $\left(\boldsymbol{x}^{4} ; \boldsymbol{y}^{4}\right)$ eleme $\mathcal{V}$-nek, akkor nézzük az $\left(\boldsymbol{x}^{1} ; \boldsymbol{y}^{1}\right)$ és $\left(\boldsymbol{x}^{4} ; \boldsymbol{y}^{4}\right)$ közti részt, a kék/lila téglalapot. Itt található $(\boldsymbol{u} ; \boldsymbol{v})$ is, és ezen a részen már nem dominálja semmi az $(i ; j)$ vegyespároson keresztül.

Ha $\left(\boldsymbol{x}^{4} ; \boldsymbol{y}^{4}\right)$ nem eleme $\mathcal{V}$-nek, akkor nézzük az $\left(\boldsymbol{x}^{3} ; \boldsymbol{y}^{3}\right)$ és $\left(\boldsymbol{x}^{2} ; \boldsymbol{y}^{2}\right)$ közti részt, a piros/lila téglalapot. Itt található $\left(\boldsymbol{x}^{4} ; \boldsymbol{y}^{4}\right)$ is, és $\left(\boldsymbol{x}^{4} ; \boldsymbol{y}^{4}\right)$-et több vegyespároson keresztül lehet dominálni a $\left(\boldsymbol{x}^{3} ; \boldsymbol{y}^{3}\right)$ és $\left(\boldsymbol{x}^{4} ; \boldsymbol{y}^{4}\right)$ között, mint eredetileg $(\boldsymbol{u} ; \boldsymbol{v})$-t az $\left(\boldsymbol{x}^{1} ; \boldsymbol{y}^{1}\right)$ és $\left(\boldsymbol{x}^{2} ; \boldsymbol{y}^{2}\right)$ között, mivel ha a kis téglában valami dominálja $\left(\boldsymbol{x}^{4} ; \boldsymbol{y}^{4}\right)$-et, akkor az dominálja $(\boldsymbol{u} ; \boldsymbol{v})$-t is az 1.3.2. állítás miatt. $\left(\boldsymbol{x}^{4} ; \boldsymbol{y}^{4}\right)$-et viszont az $(i ; j)$ vegyespároson keresztül nem lehet dominálni a piros téglalapban, mert az alsó oldalán van.

2. $x_{i}^{3}>u_{i}$ és $y_{j}^{3}>v_{j}$ : Ha $x_{i}^{3}+y_{j}^{3} \leq a_{i j}$ egyenlőtlenség állna fenn, akkor $\left(\boldsymbol{x}^{3} ; \boldsymbol{y}^{3}\right)$ dominálná $(\boldsymbol{u} ; \boldsymbol{v})$-t, ami ellentmondana $(\boldsymbol{u} ; \boldsymbol{v})$ választásának. Legyen $(\boldsymbol{s} ; \boldsymbol{t})$ az 
14. ábra. 2.1.2. tétel bizonyítása 1

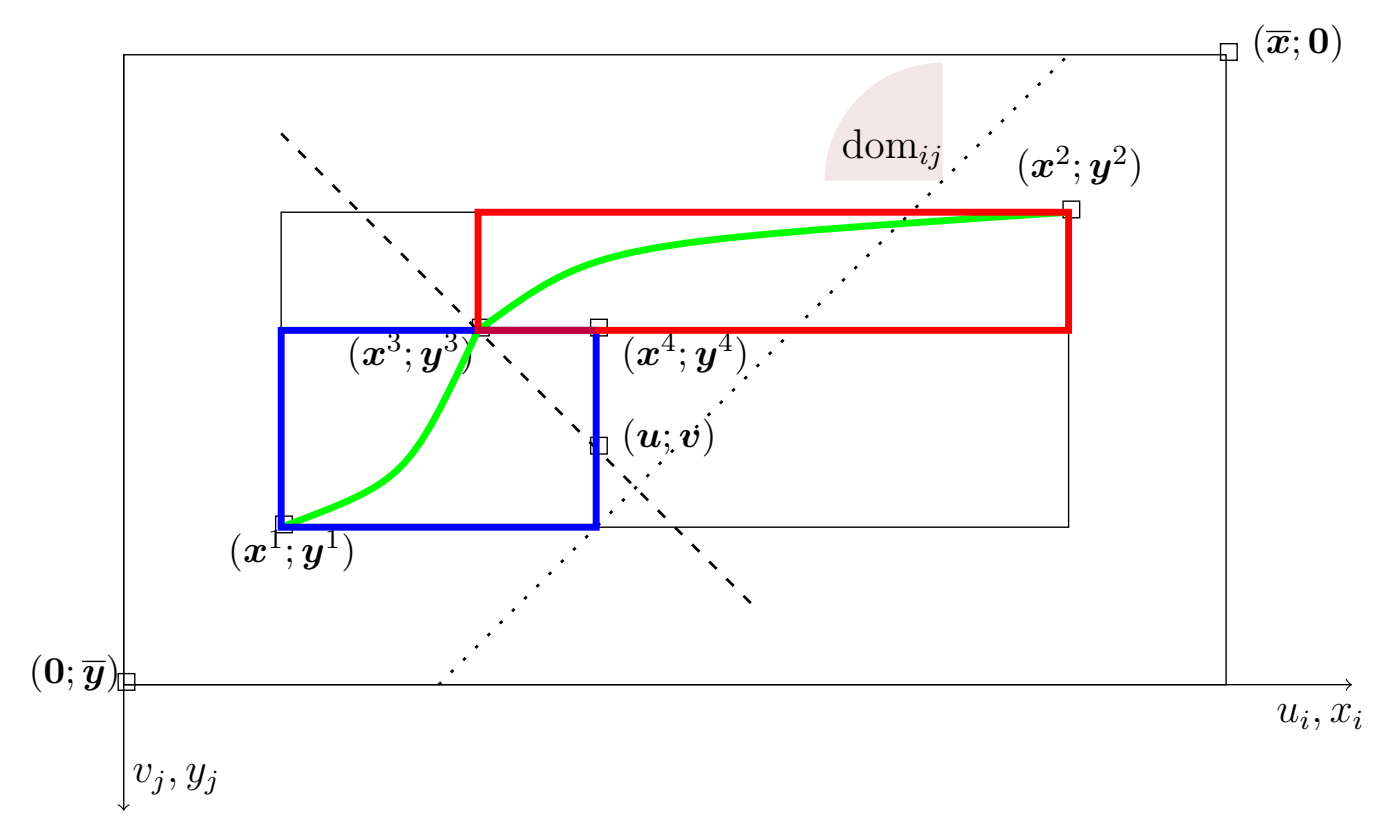

$(\boldsymbol{u} ; \boldsymbol{v})$ és $\left(\boldsymbol{x}^{3} ; \boldsymbol{y}^{3}\right)$ vektort összekötő szakasz azon pontja, amelyre $s_{i}+t_{j}=a_{i j}$ - Mivel 1.3.7. lemma miatt $\mathcal{V}$ halmaz bármely két pontját összeköti monoton görbe, így létezik az $\left(\boldsymbol{x}^{1} ; \boldsymbol{y}^{1}\right)$ és $\left(\boldsymbol{x}^{3} ; \boldsymbol{y}^{3}\right)$ pontokat összekötö görbének egy olyan $\left(\boldsymbol{x}^{4} ; \boldsymbol{y}^{4}\right)$ eleme, amelyre $x_{i}^{4}=s_{i}$ és van az $\left(\boldsymbol{x}^{3} ; \boldsymbol{y}^{3}\right)$ és $\left(\boldsymbol{x}^{2} ; \boldsymbol{y}^{2}\right)$-t összekötő görbének egy olyan $\left(\boldsymbol{x}^{5} ; \boldsymbol{y}^{5}\right)$ eleme, amelyre $y_{j}^{5}=t_{j}$. Legyen $\left(\boldsymbol{u}^{1} ; \boldsymbol{v}^{1}\right)=$ $\left(\boldsymbol{x}^{4} \vee \boldsymbol{u} ; \boldsymbol{y}^{4} \wedge \boldsymbol{v}\right)$ és $\left(\boldsymbol{u}^{2} ; \boldsymbol{v}^{2}\right)=\left(\boldsymbol{x}^{5} \wedge \boldsymbol{u}^{1} ; \boldsymbol{y}^{5} \vee \boldsymbol{v}^{1}\right)=\operatorname{med}\left(\left(\boldsymbol{x}^{4} ; \boldsymbol{y}^{4}\right)(\boldsymbol{u} ; \boldsymbol{v})\left(\boldsymbol{x}^{5} ; \boldsymbol{y}^{5}\right)\right)$. Az $\left(\boldsymbol{u}^{2} ; \boldsymbol{v}^{2}\right)$ vektor nem lehet eleme $\mathcal{V}$-nek, mert dominálja $(\boldsymbol{u} ; \boldsymbol{v})$-t az $(i ; j)$ vegyespároson keresztül. Nem lehet továbbá félelosztás sem, mert tudjuk, hogy az $\left(\boldsymbol{x}^{4} ; \boldsymbol{y}^{4}\right) ;\left(\boldsymbol{x}^{5} ; \boldsymbol{y}^{5}\right) \in \mathcal{V}$ vektorok közt van és az előzőekhez hasonlóan látható, hogy $f\left(\left(\boldsymbol{x}^{1} ; \boldsymbol{y}^{1}\right) ;(\boldsymbol{u} ; \boldsymbol{v}) ;\left(\boldsymbol{x}^{2} ; \boldsymbol{y}^{2}\right)\right)>f\left(\left(\boldsymbol{x}^{4} ; \boldsymbol{y}^{4}\right)\left(\boldsymbol{u}^{2} ; \boldsymbol{v}^{2}\right)\left(\boldsymbol{x}^{5} ; \boldsymbol{y}^{5}\right)\right)$, azaz $\left(\boldsymbol{u}^{2} ; \boldsymbol{v}^{2}\right)$-t kevesebb vegyespároson keresztül lehet dominálni $\left(\boldsymbol{x}^{4} ; \boldsymbol{y}^{4}\right)$ és $\left(\boldsymbol{x}^{5} ; \boldsymbol{y}^{5}\right)$ közti vektorral, mint $(\boldsymbol{u} ; \boldsymbol{v})$-t lehetett $\left(\boldsymbol{x}^{1} ; \boldsymbol{y}^{1}\right)$ és $\left(\boldsymbol{x}^{2} ; \boldsymbol{y}^{2}\right)$ köztivel. Ez látható a 15 , ábrán. Ugyanúgy ábrázoljuk $\left(\boldsymbol{x}^{1} ; \boldsymbol{y}^{1}\right),\left(\boldsymbol{x}^{2} ; \boldsymbol{y}^{2}\right),(\boldsymbol{u} ; \boldsymbol{v})$ pontokat mint a 14 ábrán. A különbség, hogy $\left(\boldsymbol{x}^{3} ; \boldsymbol{y}^{3}\right)$ az $(\boldsymbol{u} ; \boldsymbol{v})$ ponttól jobbra lefelé található. Tudjuk azt is, hogy szigorúan a pontozott vonal alatt kell lennie, ellenkező esetben $\left(\boldsymbol{x}^{3} ; \boldsymbol{y}^{3}\right)$ dominálná $(\boldsymbol{u} ; \boldsymbol{v})$-t. Az $(\boldsymbol{s} ; \boldsymbol{t})$ pont a szaggatott és a pontozott vonal metszéspontjában van, $\left(\boldsymbol{x}^{4} ; \boldsymbol{y}^{4}\right)$ és $\left(\boldsymbol{x}^{5} ; \boldsymbol{y}^{5}\right)$ pedig a zöld $\mathcal{V}$-beli görbének olyan pontjai, amelyek $(\boldsymbol{s} ; \boldsymbol{t})$-től lefelé illetve jobbra vannak. $\left(\boldsymbol{u}^{2} ; \boldsymbol{v}^{2}\right)$ az $\left(\boldsymbol{x}^{4} ; \boldsymbol{y}^{4}\right),(\boldsymbol{u} ; \boldsymbol{v})$ és $\left(\boldsymbol{x}^{5} ; \boldsymbol{y}^{5}\right)$ mediánja. Az ábrán ez egybeesik $(\boldsymbol{s} ; \boldsymbol{t})$-vel. Ez természetesen nem azt jelenti, hogy $(\boldsymbol{s} ; \boldsymbol{t})=\left(\boldsymbol{u}^{2} ; \boldsymbol{v}^{2}\right)$, 
csak az $(i ; j)$ vegyespáros tagjai kapják ugyanazt a két vektorban. $\left(\boldsymbol{u}^{2} ; \boldsymbol{v}^{2}\right)$ dominálja $(\boldsymbol{u} ; \boldsymbol{v})$-t, mivel a pontozott vonalon van $(\boldsymbol{u} ; \boldsymbol{v})$-től szigorúan jobbra lefelé, ezért nem lehet eleme $\mathcal{V}$-nek. Ha félelosztás lenne, akkor $\left(\boldsymbol{x}^{4} ; \boldsymbol{y}^{4}\right)$ és $\left(\boldsymbol{x}^{5} ; \boldsymbol{y}^{5}\right)$ közti rész nézzük, amiben $\left(\boldsymbol{u}^{2} ; \boldsymbol{v}^{2}\right)$ is található. Ez az ábrán a kék téglalap. $\left(\boldsymbol{u}^{2} ; \boldsymbol{v}^{2}\right)$-t kevesebb vegyespároson keresztül lehet dominálni ebben a téglában, mint $(\boldsymbol{u} ; \boldsymbol{v})$-t lehetett az eredetiben, mivel a kicsiben az $(i ; j)$ vegyespáros már nem tud dominálni.

15. ábra. 2.1.2. tétel bizonyítása 2

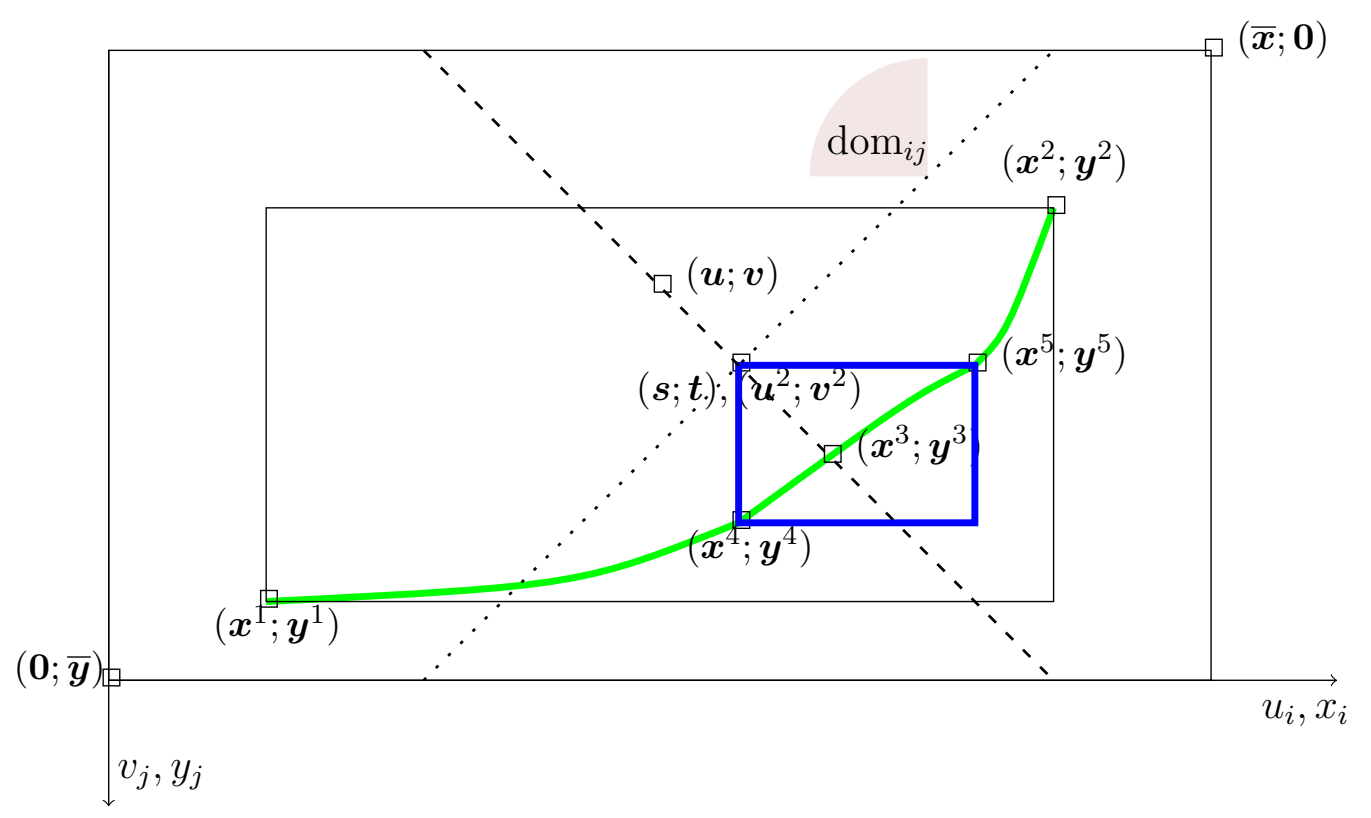

Ha $\left(\boldsymbol{u}^{2} ; \boldsymbol{v}^{2}\right)$ nem félelosztás, akkor az csak azért lehet, mert a koordinátáinak az összege nagyobb mint a nagykoalíció értéke. Ebben az esetben az $\left(\boldsymbol{x}^{4} \wedge \boldsymbol{u} ; \boldsymbol{y}^{4} \vee \boldsymbol{v}\right)$ és $\left(\boldsymbol{x}^{5} \vee \boldsymbol{u} ; \boldsymbol{y}^{5} \wedge \boldsymbol{v}\right)$ vektorok közül legalább az egyik szigorú félelosztás kell hogy legyen, mivel tegyük fel, hogy $\left(\boldsymbol{x}^{4} \wedge \boldsymbol{u} ; \boldsymbol{y}^{4} \vee \boldsymbol{v}\right)$ nem szigorú félelosztás. Ekkor $\left(\boldsymbol{x}^{4} ; \boldsymbol{y}^{4}\right)$ és $(\boldsymbol{u} ; \boldsymbol{v})$ másik hálókombinációja $\left(\boldsymbol{u}^{1} ; \boldsymbol{v}^{1}\right)=\left(\boldsymbol{x}^{4} \vee \boldsymbol{u} ; \boldsymbol{y}^{4} \wedge \boldsymbol{v}\right)$ félelosztás. $\left(\boldsymbol{u}^{1} ; \boldsymbol{v}^{1}\right)$ és $\left(\boldsymbol{x}^{5} ; \boldsymbol{y}^{5}\right)$ egyik hálókombinációja $\left(\boldsymbol{u}^{2} ; \boldsymbol{v}^{2}\right)$, amiről tudjuk, hogy nem félelosztás. Ekkor viszont a másik hálókombináció $\left(\boldsymbol{x}^{5} \vee \boldsymbol{u} ; \boldsymbol{y}^{5} \wedge \boldsymbol{v}\right)$ szigorú félelosztás.

Szimmetria miatt feltehetö, hogy $\left(\boldsymbol{x}^{4} \wedge \boldsymbol{u} ; \boldsymbol{y}^{4} \vee \boldsymbol{v}\right)$ szigorú félelosztás. Jelöljük ezt a vektort $\left(\boldsymbol{u}^{3} ; \boldsymbol{v}^{3}\right)$-mal. Az előző pontokhoz hasonlóan $\left(\boldsymbol{u}^{3} ; \boldsymbol{v}^{3}\right)$ az $\left(\boldsymbol{x}^{1} ; \boldsymbol{y}^{1}\right)$ és $\left(\boldsymbol{x}^{4} ; \boldsymbol{y}^{4}\right)$ vektorok között van, és 1.3.2. állítás miatt ha ezen két vektor között valami dominálja, az dominálja $(\boldsymbol{u} ; \boldsymbol{v})$-t is. Ha $u_{i}^{3}+v_{j}^{3} \geq a_{i j}$ teljesül, akkor $\left(\boldsymbol{u}^{3} ; \boldsymbol{v}^{3}\right)$ at már $(\boldsymbol{u} ; \boldsymbol{v})$-vel ellentétben már nem lehet dominálni az $(i ; j)$ vegyespároson 
keresztül, ami ellentmondana $(\boldsymbol{u} ; \boldsymbol{v}),\left(\boldsymbol{x}^{1} ; \boldsymbol{y}^{1}\right)$ és $\left(\boldsymbol{x}^{2} ; \boldsymbol{y}^{2}\right)$ választásának. Abban az esetben, ha $u_{i}^{3}+v_{j}^{3}<a_{i j}$ teljesül, akkor ugyan még lehet dominálni $\left(\boldsymbol{u}^{3} ; \boldsymbol{v}^{3}\right)$-at az $(i ; j)$ koalíción keresztül, de már $(\boldsymbol{u} ; \boldsymbol{v})$-nél „kevésbé szegi meg” az $(i ; j)$ párhoz tartozó magegyenlőtlenséget, mivel $u_{i}+v_{j}<u_{i}^{3}+v_{j}^{3}<a_{i j}$. Ahogy a 16 , ábrán is látszik, az $\left(\boldsymbol{u}^{3} ; \boldsymbol{v}^{3}\right)$ pont már közelebb van a pontozott vonalhoz, mint $(\boldsymbol{u} ; \boldsymbol{v})$. Ha ugyanezt a lépést megcsinálnánk még egyszer csak $\left(\boldsymbol{x}^{2} ; \boldsymbol{y}^{2}\right)$ helyett $\left(\boldsymbol{x}^{4} ; \boldsymbol{y}^{4}\right)$, és $(\boldsymbol{u} ; \boldsymbol{v})$ helyett $\left(\boldsymbol{u}^{3} ; \boldsymbol{v}^{3}\right)$ választással, akkor kapnánk egy újabb szigorú félelosztást, amely „még kevésbé szegi meg” az $(i ; j)$ pároshoz tartozó magegyenlötlenséget. A kérdés már csak annyi, hogy mi garantálja, hogy véges sok ismétlés után már nem fogja megszegni, azaz átlépjük a szaggatott vonalat. Ehhez még egy apró változtatásra szükség van.

Ha megnézzük a 16 . ábrát, látszik, hogy az $(\boldsymbol{u} ; \boldsymbol{v})$-től jobbra lefelé eső nyílt síknegyedben a zöld görbének szigorúan a pontozott vonal alatt kell haladnia, ellenkező esetben $\mathcal{V}$-nek az a pontja dominálná $(\boldsymbol{u} ; \boldsymbol{v})$-t. Ez azt jelenti, hogy minden $(\boldsymbol{x} ; \boldsymbol{y}) \in \mathcal{V}$-re amelyre $x_{i}>u_{i}$ és $y_{j}>v_{j}$ teljesül, $x_{i}+y_{j}>a_{i j}$. Fontos, hogy nyílt síknegyedet írtunk, mert zártra nem biztos, hogy igaz. A zöld vonal pont $(\boldsymbol{u} ; \boldsymbol{v})$ alatt elmetszheti a pontozott vonalat, mert az a vektor nem dominálná $(\boldsymbol{u} ; \boldsymbol{v})$-t. Nekünk viszont zárt síknegyedre lesz szükségünk.

Most fogjuk kihasználni, hogy $\left(\boldsymbol{u}^{3} ; \boldsymbol{v}^{3}\right)$ szigorú félelosztás, így ha egy nagyon kicsivel megnöveljük az $u_{i}^{3}$ és $v_{j}^{3}$ koordinátát, akkor továbbra is egy $\left(\boldsymbol{x}^{1} ; \boldsymbol{y}^{1}\right)$ és $\left(\boldsymbol{x}^{4} ; \boldsymbol{y}^{4}\right)$ közti félelosztást kapunk. Jelöljük ezt a megnövelt vektort $\left(\boldsymbol{u}^{4} ; \boldsymbol{v}^{4}\right)$-gyel. Ha egy vektor dominálja $\left(\boldsymbol{u}^{4} ; \boldsymbol{v}^{4}\right)$-et, az nyilván dominálja $\left(\boldsymbol{u}^{3} ; \boldsymbol{v}^{3}\right)$-at is. a 16 , ábrán ez azt jelenti, hogy az $\left(\boldsymbol{u}^{3} ; \boldsymbol{v}^{3}\right)$-ból egy kicsit jobbra lefelé mozdulunk. Erre a pontra már igaz, hogy a tőle jobbra lefelé eső zárt síknegyedben a zöld görbe szigorúan a pontozott vonal alatt van, azaz $\forall(\boldsymbol{x} ; \boldsymbol{y}) \in \mathcal{V}$-re amelyre $x_{i}>u_{i}^{4}$ és $y_{j}>v_{j}^{4}$ teljesül fennáll az $x_{i}+y_{j}>a_{i j}$. egyenlötlenség. Legyen $c$ ezen a halmazon az $x_{i}+y_{j}-a_{i j}$ érték minimuma. Az ábrán ez azt jelenti, hogy a zöld vonal legalább mennyivel van a pontozott vonal alatt az $\left(\boldsymbol{u}^{4} ; \boldsymbol{v}^{4}\right)$-től jobbra lefelé eső zárt síknegyedben. Ez a minimum létezik, mert 2.1.7. lemma miatt $\mathcal{V}$ zárt, így egy korlátos zárt halmazon vizsgálunk egy folytonos függvényt, ami felveszi a minimumát. c-ről tudjuk, hogy pozitív, és innentől kezdve, ha $\left(\boldsymbol{u}^{4} ; \boldsymbol{v}^{4}\right)$ pontból indulunk ki az eredeti $(\boldsymbol{u} ; \boldsymbol{v})$ helyett és elvégezzük azokat a lépéseket, amelyekkel megkaptuk $\left(\boldsymbol{u}^{3} ; \boldsymbol{v}^{3}\right)$-at, akkor legalább $c$-vel közelebb kerülünk a pontozott vonalhoz, így véges sok lépés után biztosan átlépünk rajta, azaz kapunk egy olyan pontot, amelyet már kevesebb koalíción keresztül lehet dominálni, mint $(\boldsymbol{u} ; \boldsymbol{v})$-t, ami ellentmond $(\boldsymbol{u} ; \boldsymbol{v})$ választásának. 
16. ábra. 2.1.2. tétel bizonyítása 3

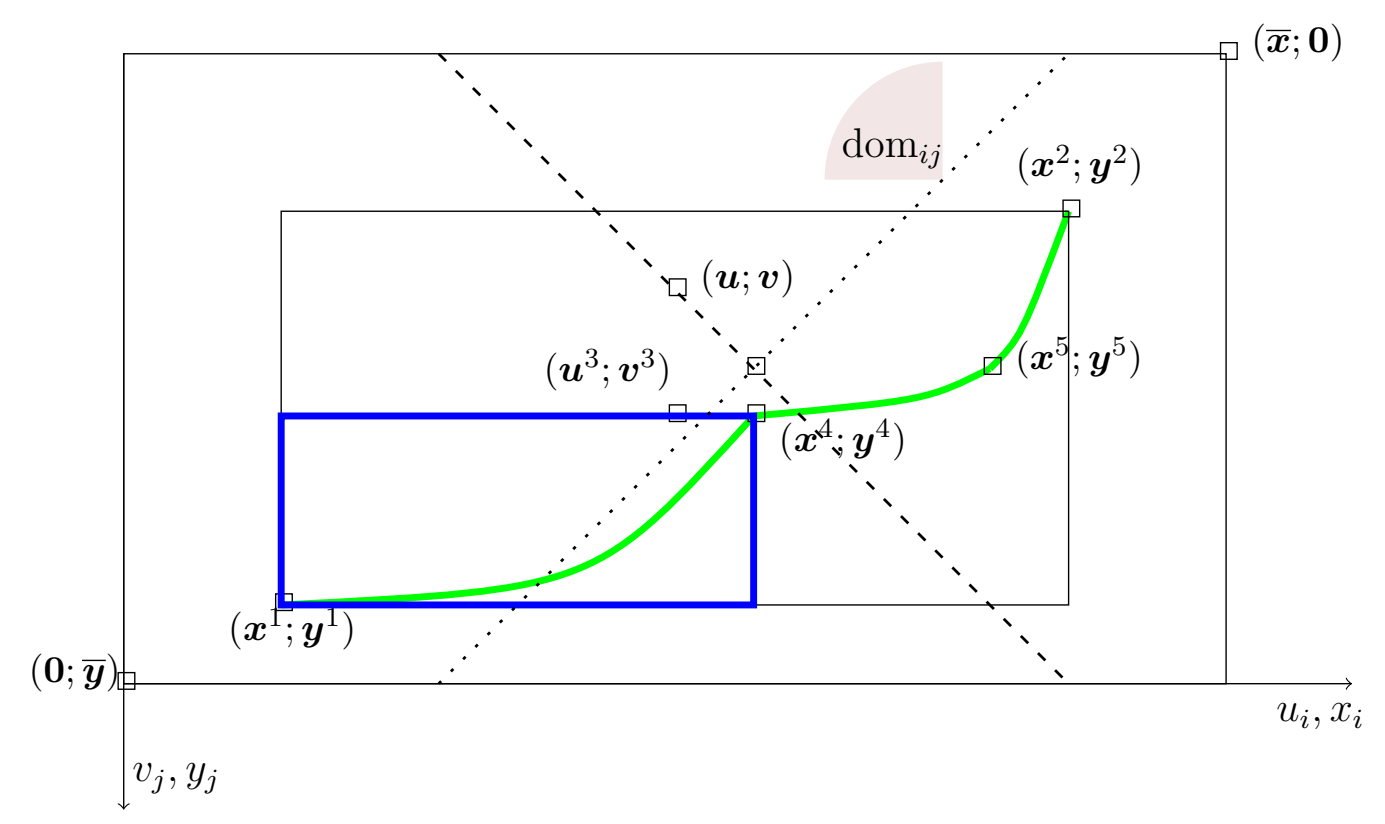

2.1.8. Megjegyzés. Könnyen belátható, hogy a tétel feltételei élesek, egyiket sem hagyhatjuk el, mert akkor már más, nem stabil halmazok is teljesíteni fogják a maradék hármat.

1. Ha a belső stabilitást nem követeljük meg, akkor a principal section teljesíti a maradék hármat, de csak elfajult esetben (ha a generáló mátrix diagonális) lesz belső stabil is.

2. Ha az összefüggőséget hagyjuk el, akkor nézzük az $A=\left[\begin{array}{ll}1 & 1\end{array}\right]$ mátrix által meghatározott kesztyüjátékot és legyen $\mathcal{V}=\left\{(1 ; 0,0),\left(0 ; \frac{1}{2}, \frac{1}{2}\right)\right\}$. A halmaz egyik pontja sem dominálja a másikat, az elsőben mindkét vevő, a másodikban az eladó kifizetése 0 , továbbá tartalmazza bármely két pontja közti rész magját, mert ez a mag megegyezik a $\mathcal{V}$ halmazzal.

3. Ha $\mathcal{V}$-nek nem kell olyan pontokat tartalmaznia, amikben minden kifizetést az egyik játékososztály kap meg, csak a maradék 3 feltételnek kell teljesülnie, akkor erre az elosztáshalmaz bármely egyelemű részhalmaza jó lesz.

4. A negyedik feltételnél már akkor sem biztos, hogy stabil halmazt kapunk, ha csak annyit követelünk meg, hogy bármely két pont közti elosztások magját tartalmaz- 
za $\mathcal{V}$ : Legyen $A=\left[\begin{array}{ll}2 & 1\end{array}\right]$ és $\mathcal{V}$ a $(2 ; 0,0)$ és $(0 ; 0,2)$ pontokat összekötő szakasz, azaz azok az elosztások, amelyekben az első vevő nem kap semmit. Erre a halmazra nyilván teljesül az első 3 feltétel valamint tartalmazza bármely két pontja közti elosztások magját, mivel ez pontosan a két pontot összekötő szakasz. A két pontja közti félelosztások magját viszont nem tartalmazza, mivel például az $(1 ; 0,0)$ vektor a $(2 ; 0 ; 0)$ és $(0 ; 0,2)$ vektorok között van, és ezek közt egyetlen félelosztás sem dominálja, mivel csak olyan vektorok dominálják, amiben az első vevő pozitív mennyiséget kap.

Ha megnézzük a feltételeket elég természetes módon adódik a kérdés, hogy ha nem hozzárendelési játékokkal foglakozunk, hanem az összes TU játékkal, akkor teljesülneke minden stabil halmazra vagy sem. A belső stabilitás természetesen teljesül a stabil halmazok definíciója miatt, a másik háromnál azonban nem ilyen egyértelmü a helyzet. A következő két példán jól látszik, hogy még a legegyszerübb nem hozzárendelési játékokban sem szükséges feltételek.

8. Példa. Nézzük a három szereplős egyszerü többségi játékot:

$$
\begin{aligned}
& P=\{1 ; 2 ; 3\}, v(S)= \begin{cases}0 & h a|S|<2 \\
1 & h a|S| \geq 2\end{cases} \\
& \text { Legyen } \mathcal{V}_{1}=\left\{\left(\frac{1}{2} ; \frac{1}{2} ; 0\right),\left(\frac{1}{2} ; 0 ; \frac{1}{2}\right),\left(0 ; \frac{1}{2} ; \frac{1}{2}\right)\right\} \\
& \mathcal{V}_{2}=\left\{\left(\frac{1}{10} ; x ; \frac{9}{10}-x\right) \in \mathcal{I}: 0 \leq x \leq \frac{9}{10}\right\}
\end{aligned}
$$

Könnyen leellenőrizhető, hogy $\mathcal{V}_{1}$ és $\mathcal{V}_{2}$ is stabil halmaz a $(P, v)$ játékban. Ezt a két halmazt ábrázoltuk a 17. és 18 , ábrán. Minkettőn az elosztáshalmaz a nagy háromszög, a $\mathcal{V}_{1}$ és $\mathcal{V}_{2}$ halmazokat pedig zöldel jelöltük. Az első ábrán mindhárom pont egy $60^{\circ}$ os nyílt szögtartományt dominál, így a középső áromszöget mindhárom, míg a szélső háromszögeket csak a szembenlévő pont dominálja. A második ábrán minden pont három darab $60^{\circ}$-os nyílt szögtartományt dominál. $\mathcal{V}_{2}$ egy pontjára be is jelöltük az általa dominált részt.

Látszik, $\mathcal{V}_{1}$ halmaz nem összefüggő, és nem tartalmazza bármely két pontja közti félelosztások magját sem, mivel például az első két eleme közti részen semmi nem dominálja például az $\left(\frac{1}{2} ; \frac{1}{4} ; \frac{1}{4}\right)$ elosztást (ezt a harmadik pont dominálja), de ez mégsem eleme $\mathcal{V}_{1}$-nek.

A karakterizációban szereplő harmadik feltételt (tartalmaz egy olyan pontot ahol minden eladó és egy olyat, ahol minden vevő kifizetése 0) nem egyértelmü, hogy hogyan általánosítsuk a $T U$ esetre, mert ott nincsenek eladók és vevők. A $\mathcal{V}_{2}$ stabil halmaz arra példa, hogy egy játékos kifizetése a halmaz minden pontjában pozitív. Ez jó 
példa olyan stabil halmazra, amely a szétosztáshalmazon (az elfogadható és elérhető kifizetésvektorok) nem stabil, mert például az $(1 ; 1 ;-1)$ szétosztást nem dominálja.

17. ábra. Egyszerü többségi stabil halmaz 1

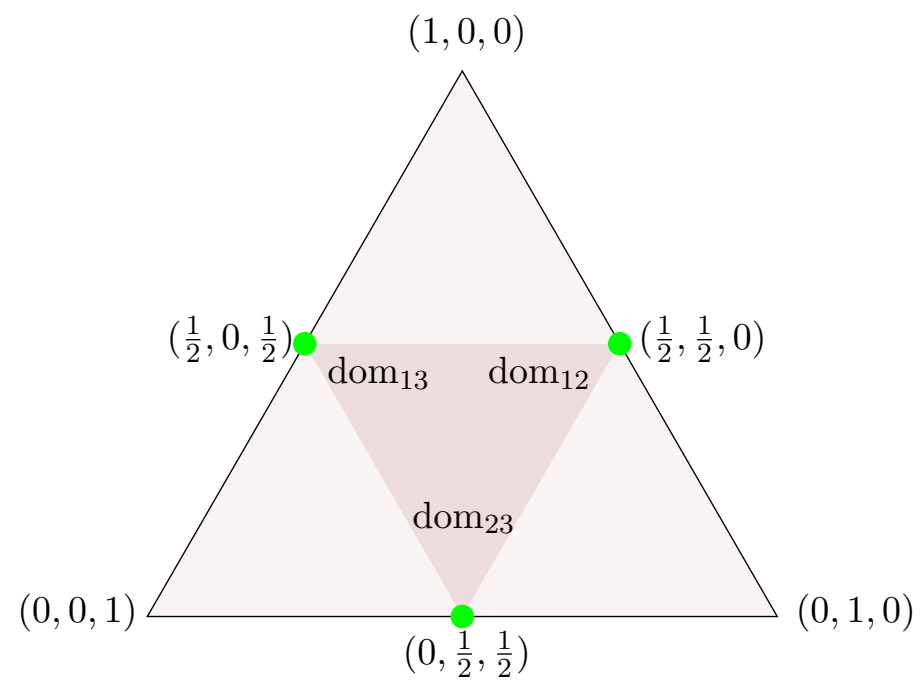

18. ábra. Egyszerü többségi stabil halmaz 2

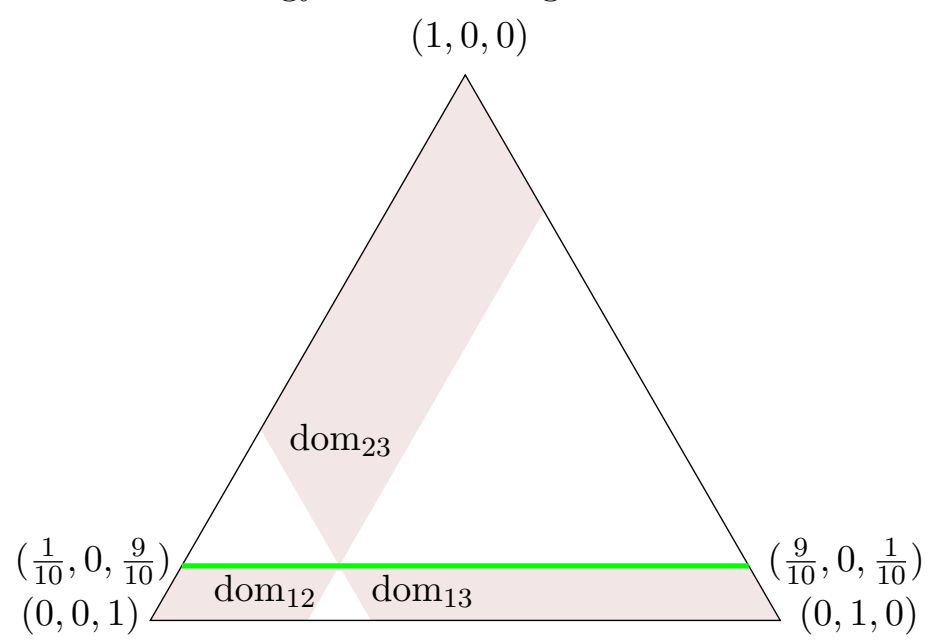

2.1.9. Megjegyzés. A bizonyítás során a dominanciarelációkban csak a vegyespárosok voltak számunkra érdekesek (az egyszemélyesek nem, mert végig félelosztásokkal dolgoztunk, a nagyobbak szintén nem, mert azok nem hatékonyak). Éppen ezért a 2.1.2. tételbeli karakterizáció akkor is igaz, ha néhány koalíciónak, amelyek nem lehetnek egyszemélyesek, vegyespárosok és a nagykoalíció lecsökkentjük az értékét. A nagykoalíciót azért vettük külön, mert ha a nagykoalíció értéke változik, akkor változik az elosztásokban kiosztandó pénzmennyiség is. 
2.1.10. Megjegyzés. a 2.1.9. megjegyzéshez hasonlóan a nagykoalíció értékét is lecsökkenthetjük akármilyen nemnegativ értékre (a nemnegativitás csak azért kell, hogy az elosztáshalmaz ne legyen üres) a 2.1.2. tétel az így kapott játékra is fennáll. Ennek oka, hogy a hatékony koalíciók halmaza továbbra sem változott meg. Ezt a megjegyzést pusztán a nagykoalíció speciális szerepe miatt vettük külön az előzootól.

A bizonyítás során már láttunk következményeit a négy karakterizáló feltételnek, amelyek sokat elárulnak $\mathcal{V}$ szerkezetéről például 2.1.3. lemmában a háló tulajdonság, vagy 2.1.5. következményben a belső stabilitás erősebb változata. A következő alfejezetben a karakterizáló feltételeket, és néhány következményét fogjuk körüljárni.

\subsection{A karakterizáció következményei}

a 2.1.2 tételbeli karakterizáció nagyon jól használható, az előző fejezetekbeli tételek bizonyításához, valamint a stabil halmazok szerkezetének további tanulmányozásához.

Már a 1.3.4 állításnál is érezhettük, hogy a hozzárendelési játékok magja és stabil halmazai közt szoros kapcsolat lehet, mivel a két halmaz háló tulajdonságának bizonyítása ugyanazon az állításon múlt. Az előző fejezetben láthattuk, hogy $\mathcal{C B}$ halmazt Shubik (1984) eredetileg nem mint a principal section magját adta meg, hanem különböző részjátékok magjainak uniójaként.

Az általában is nyilván igaz, hogy mindkettő rendelkezik a belső stabilitás tulajdonságával, és hogy a mag része bármely stabil halmaznak. A külső stabilitás megkövetelése viszont nagyon megváltoztathatja a magot (már a a 4 . példában is láttuk, hogy amikor kiegészítettük a magot stabil halmazzá, akkor elvesztette a konvexitását). Vizsgáljuk meg a 2.1.2. tételben szereplő tulajdonságokat teljesíti-e a hozzárendelési játékok magja!

2.2.1. Állítás. A hozzárendelési játékok magja teljesíti a 3. kivételével (tartalmaz egy olyan elosztást amelyben minden vevő kifizetése 0 , és egy olyat melyben minden eladóé 0) a stabilitás 2.1.2. tételbeli feltételeit.

BizONYÍTÁs.

A belső stabilitás és az összefüggőség bármely TU játék magjára igaz, az előbbi a mag definíciójából egyből adódik, utóbbi pedig azért igaz mert a mag zárt félterek metszete, ezért konvex. A negyedik tulajdonság bizonyítása egy kicsit érdekesebb, azaz hogy tartalmazza bármely két pontja közti félelosztások magját. Legyen $\left(\boldsymbol{x}^{1} ; \boldsymbol{y}^{1}\right),\left(\boldsymbol{x}^{2} ; \boldsymbol{y}^{2}\right) \in$ $\mathcal{C}$. Ezen két pont közti félelosztások magját azon $(\boldsymbol{x} ; \boldsymbol{y})$ félelosztások alkotják, amelyek $\left(\boldsymbol{x}^{1} ; \boldsymbol{y}^{1}\right)$ és $\left(\boldsymbol{x}^{2} ; \boldsymbol{y}^{2}\right)$ között vannak és bármely $(i ; j)$ párra igaz, hogy $x_{i}+y_{j} \geq a_{i j}$ vagy 
$x_{i}=x_{i}^{1} \vee x_{i}^{2}$ vagy $y_{j}=y_{j}^{1} \vee y_{j}^{2}$. Megmutatjuk, hogy ha a második vagy harmadik feltétel teljesül akkor az első is. Szimmetria miatt elég a másodikra megmutatni. A mag összefüggősége és konvexitása miatt van olyan $\left(\boldsymbol{x}^{3} ; \boldsymbol{y}^{3}\right)$ eleme a magnak $\left(\boldsymbol{x}^{1} ; \boldsymbol{y}^{1}\right)$ és $\left(\boldsymbol{x}^{2} ; \boldsymbol{y}^{2}\right)$ között, amelyre $y_{j}=y_{j}^{3}$. Erre igaz, hogy $a_{i j} \leq x_{i}^{3}+y_{j}^{3}=x_{i}^{3}+y_{j} \leq x_{i}^{1} \vee x_{i}^{2}+y_{j}=$ $x_{i}+y_{j}$.

Ennek az állításnak egy egyszerü következménye Solymosi \& Raghavan (2001) a mag stabilitásáról szóló tétele (a dolgozatban már szerepelt 1.2.1. tétel), amely éppen azt mondta ki, hogy a mag pontosan akkor stabil, ha teljesül rá a 2.1.2. tételbeli 3. tulajdonság.

A Shapley által javasolt $\mathcal{C B}_{A, \mu}$ halmaz stabilitását, melyet Núñez \& Rafels (2013) bizonyítottak is könnyen megmutathatjuk a 2.1.2. tétel segítségével, sőt az 1.4.1. tételben szereplő unicitásnál (ez az egyetlen stabil halmaz a $\mu$ maximális súlyú párosításhoz tartozó principal sectionben) többet is állíthatunk. Itt az előzőekhez hasonlóan feltesszük, hogy a mátrix foátlójában maximáis értékű párosítás található, az ehhez a párosításhoz tartozó principal sectiont nézzük, és $\boldsymbol{d}$-vel jelöljük a főátló elemeiből készített vektort.

2.2.2. Állítás. $\mathcal{C B}_{A, \mu}$ az egyetlen stabil halmaz, amely tartalmazza a $(\mathbf{0} ; \boldsymbol{d})$ és $(\boldsymbol{d} ; \mathbf{0})$ pontokat (az első amikor minden vevő a $\mu$ maximális súlyú párositásban hozzá tartozó értéket kapja, az eladók 0-t, a másik, amikor fordítva).

\section{BizONYÍTÁs.}

A halmaz stabilitásának bizonyításához le kell ellenőrizni a 2.1.2 tételben található négy feltétel teljesülését.

1. a belső stabilitás nyilvánvaló, mert $\mathcal{C B}$ halmaz egy másik halmaz $(\mathcal{B})$ magja.

2. az összefüggőséget az 1.4.3. lemmában beláttuk.

3. ez a két pont a principal section vevő- és eladóoptimális csúcsa, a $(\mathbf{0} ; \boldsymbol{d})$ és $(\boldsymbol{d} ; \mathbf{0})$ csúcsok.

4. legyen $\left(\boldsymbol{x}^{1} ; \boldsymbol{y}^{1}\right),\left(\boldsymbol{x}^{2} ; \boldsymbol{y}^{2}\right) \in \mathcal{C B}$ és legyen $(\boldsymbol{u} ; \boldsymbol{v})$ egy eleme ezen két vektor közti félelosztások magjának. az 1.4.2. lemmában beláttuk, hogy $\mathcal{C B}$ háló, így az egyszerübb jelölés miatt feltehetö, hogy $\boldsymbol{x}^{1} \leq \boldsymbol{x}^{2}$ és $\boldsymbol{y}^{1} \geq \boldsymbol{y}^{2}$ mivel két vektor illetve ezeknek a két hálókombinációja ugyanazt a téglatestet határozzák meg. Azt kell megmutatnunk, hogy ekkor $(\boldsymbol{u} ; \boldsymbol{v}) \in \mathcal{C B}$. Tegyük fel, hogy ez nem teljesül. Ekkor van olyan $(i ; j)$ vegyespáros, amelyre $u_{i}+v_{j}<a_{i j}, u_{i}<a_{i i}$ és $v_{j}<a_{j j}$. Tudjuk viszont, hogy $(\boldsymbol{u} ; \boldsymbol{v})$-t nem dominálja semmi az $\left(\boldsymbol{x}^{1} ; \boldsymbol{y}^{1}\right)$ és $\left(\boldsymbol{x}^{2} ; \boldsymbol{y}^{2}\right)$ vektorok közt az $(i ; j)$ vegyespároson keresztül, így $u_{i}=x_{i}^{2}\left(=x_{i}^{1} \vee x_{i}^{2}\right)$ vagy $v_{j}=y_{j}^{1}\left(=y_{j}^{1} \vee y_{j}^{2}\right)$ 
teljesül, mivel az $(i ; j)$ pároshoz tartozó magegyenlőtlenséget tudjuk hogy megszegi. Szimmetria miatt feltehető, hogy az első teljesül. $\left(\boldsymbol{x}^{2} ; \boldsymbol{y}^{2}\right)$-ről viszont tudjuk, hogy eleme $\mathcal{C B}$-nek, így az $x_{i}^{2}+y_{j}^{2} \geq a_{i j}, x_{i}^{2}=a_{i i}$ és $y_{j}^{2}=a_{j j}$ feltételek közül valamelyik teljesül. Mivel $x_{i}^{2}=u_{i}$ és $y_{j}^{2} \leq v_{j}$, így ha az első feltétel teljesülne, akkor $(\boldsymbol{u} ; \boldsymbol{v})$-re teljesülne az $(i ; j)$ pároshoz tartozó magegyenlőtlenség, ha a második telesül, akkor $u_{i}=a_{i i}$, ha a harmadik, akkor $v_{j}=a_{j j}$, azaz mindhárom esetben ellentmondásra jutottunk.

Az unicitás egyszerủ következménye a karakterizációban szereplő 4. feltételnek. Mivel $\mathcal{C B}$ halmaz pontosan a $(\mathbf{0} ; \boldsymbol{d})$ és $(\boldsymbol{d} ; \mathbf{0})$ pontok közti félelosztások magja, így minden stabil halmaz, amely tartalmazza ezt a két pontot, az tartalmazza $\mathcal{C B}$-t is. Végül mivel egy stabil halmaz nem tartalmazhat szigorúan egy másikat, ezért ez az egyetlen $(\mathbf{0} ; \boldsymbol{d})$ és $(\boldsymbol{d} ; \mathbf{0})$ pontokat tartalmazó stabil halmaz.

Beláttuk tehát, hogy a $\mathcal{C B}_{A, \mu}$ halmazt már a vevő- és eladóoptimális pontja is meghatározza. Adódik a kérdés, hogy ez általában teljesül-e, azaz a hozzárendelési játékok osztályán egy stabil halmazt meghatároz-e a vevő és eladóoptimális pontja, és ha nem, akkor tudunk-e mondani olyan részhalmazt, amely már meghatározza.

A következő példából könnyen látszik, hogy a vevő- és eladóoptimális csúcspont általában nem elég. Erre az egyik legegyszerübb példa az egy eladós, két vevős kesztyüjáték, az $A=\left[\begin{array}{ll}1 & 1\end{array}\right]$ mátrixhoz tartozó hozzárendelési játék. Könnyen leellenőrizhető, hogy az $(1 ; 0,0),\left(\frac{1}{2} ; \frac{1}{2}, 0\right),\left(0 ; \frac{1}{2}, \frac{1}{2}\right)$ pontokat és az $(1 ; 0,0),\left(\frac{1}{2} ; 0, \frac{1}{2}\right),\left(0 ; \frac{1}{2}, \frac{1}{2}\right)$ pontokat összekötő töröttvonal is stabil halmazt alkot, és a két görbének azonosak a végpontjai. Ebben a példában az is megmutatható, hogy pontosan a két különböző, maximális értékủ párosításhoz tartozó $\mathcal{C B}$ halmazokat határozza meg a két végpontjuk, mivel a karakterizáció segítségével könnyen látható, hogy a stabil halmazok ebben az esetben az $(1 ; 0,0)$ pontot a $(0 ; x, 1-x)$ egyenessel összekötő, az elosztáshalmazbeli, koordinátánként monoton, folytonos görbék lesznek. Erre kicsit általánosabban az egy-eladós esettel foglalkozó fejezetben fogunk kitérni.

Azonban az sem igaz, hogy csak a $\mathcal{C B}_{A, \mu}$ típusú halmazokat határozza meg a két végpontjuk. A következő példában mutatunk egy stabil halmazt, amelyet meghatároz a vevő- és eladóoptimális csúcspontja, azaz nincs más stabil halmaz, amely tartalmazza ezt a két elosztást, de nem $\mathcal{C B}$ típusú a halmaz.

9. Példa. Vegyük az $A=\left[\begin{array}{ll}1 & 2 \\ 0 & 3\end{array}\right]$ mátrixhoz tartozó hozzárendelési játékot.

Legyen $\mathcal{V}$ a mag $(a(0,0 ; 1,3),(1,0 ; 0,3),(1,2 ; 0,1)$ és a $(0,1 ; 1,2)$ pontok által meghatározott trapéz) kiegészítve a mag eladóoptimális $(1,2 ; 0,1)$ csúcsát és a $(2,2 ; 0,0)$ pontot összekötö szakasszal. 
Ellenőrizzük le, hogy ez a halmaz stabil. Vegyünk egy $(\boldsymbol{x} ; \boldsymbol{y}) \in \mathcal{I} \backslash \mathcal{V}$ pontot,

- ha $x_{1}+y_{1}<1$, akkor $(\boldsymbol{x} ; \boldsymbol{y})$-t dominálja a mag $(0,0 ; 1,3)$ és $(1,0 ; 0,3)$ pontjait összekötő szakaszának valamelyik pontja az $(1 ; 1)$ vegyespároson keresztül.

- ha $x_{1}+y_{1}=1$, akkor $x_{2}+y_{2}=3$. Tudjuk, hogy $(\boldsymbol{x} ; \boldsymbol{y})$ nincs a magban, ezért $x_{1}+y_{2}<2$ egyenlőtlenségnek kell teljesülnie. A mag $(1,2 ; 0,1)$ és $(0,1 ; 1,2)$ csúcsokat összekötő szakasza csak akkor nem dominálja $(\boldsymbol{x} ; \boldsymbol{y})$ pontot az $(1 ; 2)$ vegyespároson keresztül, ha $x_{1}=1$ és $y_{2}<1$. Az ilyen elosztásokat viszont a magot kiegészítő szakasz dominálja az $(1 ; 2)$ vegyespároson keresztül.

- ha $x_{1}+y_{1}>1$, akkor $x_{2}+y_{2}<3$. A mag $(1,0 ; 0,3)$ és $(1,2 ; 0,1)$ csúcsait összekötö szakasz csak akkor nem dominálja $(\boldsymbol{x} ; \boldsymbol{y})$-t a $(2 ; 2)$ vegyespároson keresztül, ha $x_{2}>2$. Ekkor viszont $x_{1}+y_{2}<2$, és ezért a $(2,2 ; 0,0),(1,2 ; 0,1),(0,1 ; 1,2)$ töröttvonal valamelyik pontja dominálja $(\boldsymbol{x} ; \boldsymbol{y})$-t az $(1 ; 2)$ vegyespároson keresztül.

Láttuk tehát, hogy $\mathcal{V}$ stabil. Most megmutatjuk, hogy ez az egyetlen stabil halmaz, amely tartalmazza a $(0,0 ; 1,3)$ és $(2,2 ; 0,0)$ pontokat. Legyen $\mathcal{V}^{\prime}$ egy stabil halmaz az $A$ mátrixhoz tartozó játékban, amely tartalmazza ezt a két pontot. Tudjuk, hogy a játék magját tartalmazza minden stabil halmaz, így $\mathcal{C} \subseteq \mathcal{V}^{\prime}$. az 1.3.7. és 2.1.3. lemmák miatt $\mathcal{V}^{\prime}$ bármely két pontját összeköti koordinátánként monoton görbe, így az $(1,2 ; 0,1) \in \mathcal{C}$ és $(2,2 ; 0,0)$ pontjait is. Ez csak úgy lehet, ha $\mathcal{V}^{\prime}$ tartalmazza ezen két pontot összekötő szakaszt. Azt kaptuk tehát, hogy $\mathcal{V} \subseteq \mathcal{V}^{\prime}$. De tudjuk, hogy mindkét halmaz stabil, ez viszont csak akkor fordulhat elö, ha $\mathcal{V}=\mathcal{V}^{\prime}$.

2.2.3. Megjegyzés. Az előző példában elég lett volna a $(2,2 ; 0,0)$ pontot megadni, mivel a másik pont része a magnak, így automatikusan része minden stabil halmaznak.

Láttuk tehát, hogy két pont megadása nem mindig elég. A következő állításban megmutatjuk, hogy ha megadunk egy, az eladó- és vevőoptimális pontokat összekötő görbét, akkor az már egyértelmüen meghatározza a stabil halmazt.

2.2.4. Állítás. Legyen $\mathcal{V}$ egy stabil halmaz az A mátrixhoz tartozó hozzárendelési játékban, $(\overline{\boldsymbol{x}} ; \mathbf{0})$ és $(\mathbf{0} ; \overline{\boldsymbol{y}})$ az eladó-, illetve vevőoptimális pontjai és $\mathcal{X} \subseteq \mathcal{V}$ egy a két pontot összekötö görbe. Ekkor $\mathcal{V}$ az egyetlen stabil halmaz, amely tartalmazza $\mathcal{X}$-et.

\section{BIZONYÍTÁs.}

Tegyük fel, hogy van két stabil halmaz, ami tartalmazza $\mathcal{X}$-et. Ez a két halmaz legyen $\mathcal{V}$ és $\mathcal{V}^{\prime}$. Ellenőrizzük le, hogy a két halmaz metszetére teljesülnek-e a stabilitásnak a 2.1.2. tételben szereplő feltételei. 
1. A belső stabilitás teljesül, mivel $\mathcal{V}$ is teljesíti, így $\mathcal{V}$-nek minden részhalmaza, tehát $\mathcal{V} \cap \mathcal{V}^{\prime}$ is.

2. Összefüggő, mivel $\mathcal{V}$ és $\mathcal{V}^{\prime}$ is háló, így a metszetük is, és az 1.3.7. állítás szerint ha egy hálóban van, az első koordinátákban maximális és minimális elemet összekötő görbe, akkor a háló összefüggő.

3. Tartalmaz olyan pontot, amelyben minden vevő kifizetése 0 és olyat is, amelyben minden eladó kifizetése 0 , mivel $(\overline{\boldsymbol{x}} ; \mathbf{0})$ és $(\mathbf{0} ; \overline{\boldsymbol{y}})$ is eleme $\mathcal{V}$-nek és $\mathcal{V}^{\prime}$-nek is, így a metszetüknek is.

4. Tartalmazza bármely két pontja közti félelosztások magját, mivel ez igaz $\mathcal{V}$-re és $\mathcal{V}^{\prime}$-re is, így a metszetükre is.

Azt kaptuk tehát, hogy a két stabil halmaz metszete is stabil, de mivel egy stabil halmaz sem szigorú részhalmaza egy másik stabil halmaznak, ezért $\mathcal{V}=\mathcal{V}^{\prime}$-nek kell teljesülnie.

a 2.1.2. tételbeli karakterizáció 3. feltételéből következik egy másik érdekes tulajdonsága is a stabil halmazoknak a hozzárendelési játékok osztályán. A külső stabilitásnál csak annyit követeltünk meg, hogy $\mathcal{V}$-nek dominálnia kell az összes nem $\mathcal{V}$ beli elosztást, viszont azokat a szétosztásokat, amelyek nem elosztások nem kell dominálnia. A 3. feltétel miatt viszont azokat is dominálja, mivel az ilyen szétosztásokban valamelyik játékos kifizetése negatív, ezért ezt a szétosztást dominálja az ezen játékosból álló egyszemélyes koalíción keresztül $\mathcal{V}$-nek az a pontja, ahol ő 0-t kap. Ezt az észrevételt megfogalmazzuk egy külön állításban.

2.2.5. Állítás. Hozzárendelési játékok esetén minden stabil halmaz stabil a szétosztáshalmazra nézve, azaz $\mathcal{I}^{*}$-stabil.

Általában a TU játékokra nem teljesül ez a tulajdonság. a 8. példában található 3 személyes egyszerü többségi játékban $(|P|=3$ és az 1 személyes koalíciók értéke 0 , a 2- és 3 személyeseké 1$)$ szereplő $\left.\mathcal{V}_{2}\left(=\left\{\left(\frac{1}{10} ; x ; \frac{9}{10}-x\right): 0 \leq x \leq \frac{9}{10}\right)\right\}\right)$ halmaz nem dominálja az összes szétosztást, például a $(-9 ; 5 ; 5)$-öt sem, mivel csak az első játékosból álló egyszemélyes koalíció jöhetne szóba. mivel a másik két játékos sokkal többet kap mint $\mathcal{V}_{2}$ bármelyik pontjában. Viszont ez a játékos nem tud dominálni, mert számára $\mathcal{V}_{2}$ egyik pontja sem elérhető. Van viszont olyan halmaz, amely stabil a szétosztáshalmazra nézve $\left(\mathcal{I}^{*}\right.$-stabil), de nem stabil. Ez úgy fordulhat elö, hogy a halmaz nem része az elosztáshalmaznak. Elég a $\mathcal{V}_{2}$ halmazhoz egyetlen pontot hozzávennünk és elérhetjük az $\mathcal{I}^{*}$-stabilitást, ahogy azt a következő példában láthatjuk. 
10. Példa. Vegyük a 8. példában is szereplő egyszerü többségi játékot és legyen $\mathcal{V}_{3}=$ $\left.\left\{\left(\frac{1}{10} ; x ; \frac{9}{10}-x\right): 0 \leq x \leq \frac{9}{10}\right)\right\} \cup\left(-\frac{8}{10} ; \frac{9}{10} ; \frac{9}{10}\right)$.

$\mathcal{V}_{3}$ halamz $\mathcal{I}^{*}$-stabilitását könnyen beláthatjuk:

- $\mathcal{V}_{3}$ belső stabil, mert láttuk, hogy az unió első része (a 8 példában szereplő $\mathcal{V}_{2}$ halmaz) stabil, így semelyik két pontja nem dominálja egymást. és egyik pontja sem dominálja a $\left(-\frac{8}{10} ; \frac{9}{10} ; \frac{9}{10}\right)$ pontot, mert ez csak az első játékoson keresztül történhetne, de számára nem elérhető $\mathcal{V}_{2}$. Ez a pont sem dominálja $\mathcal{V}_{2}$ egyetlen pontját sem, mivel a $\left(-\frac{8}{10} ; \frac{9}{10} ; \frac{9}{10}\right)$ pont csak az első játékost tartalmazó koalíciók számára elérhető, az első játékos viszont $\mathcal{V}_{2}$ minden pontjában többet kap $-\frac{8}{10}$-nél.

- $\mathcal{V}_{3}$ külső $\mathcal{I}^{*}$-stabil, mert $\mathcal{V}_{2}$ stabilitása miatt ez a rész dominál minden nem $\mathcal{V}_{3}$ beli elosztást. Azokat a szétosztásokat, amelyekben a 2. játékos kifizetése negatív dominálja az $\left(\frac{1}{10} ; 0 ; \frac{9}{10}\right) \in \mathcal{V}_{3}$, ahol a 3 . játékos kifizetése negatív az $\left(\frac{1}{10} ; \frac{9}{10} ; 0\right)$ vektor. Maradtak azok a szétosztások, amelyekben az 1. játékos kifizetése negatív. Ezek közül azokat, ahol a 2. játékos kifizetése kisebb $\frac{9}{10}$-nél, dominálja az $\left(\frac{1}{10} ; \frac{9}{10} ; 0\right)$ vektor, és hasonlóan ahol a 3 . játékos kifizetése kisebb $\frac{9}{10}$-nél azokat dominálja az $\left(\frac{1}{10} ; 0 ; \frac{9}{10}\right)$ vektor. Kimaradt még az a rész, ahol az első játékos kifizetése negatív, a másik kettőé pedig legalább $\frac{9}{10}$. Ennek a halmaznak egyetlen olyan eleme van, amelyben az első játékos kifizetése legalább $-\frac{8}{10}$, ez éppen a $\mathcal{V}_{3}$-ban lévő $\left(-\frac{8}{10} ; \frac{9}{10} ; \frac{9}{10}\right)$ pont. Ez a szétosztás pedig dominálja az összes többi megmaradt szétosztást az első játékosból álló koalíción keresztül, mert azokban az első játékos kifizetése kisebb mint $-\frac{8}{10}$.

Ezt láthatjuk a 19 ábrán is. Ez nagyon hasonló a 18 , ábrához. A háromszög az elosztáshalmaz, $\mathcal{V}_{3}$ halmaz a háromszögben található zöld szakasz és az alsó pont uniója. Az ábrán minél sötétebb egy rész, annál több koalíción keresztül lehet dominálni. A kétszemélyes koalíciókon keresztül dominált pontokat megkaphatjuk a 18. ábrához hasonlóan, csak a itt a háromszögön kívüli részt is nézzük. A kétszemélyes koalíciók mindent dominálnak kivéve három $60^{\circ}$-os szögtartományt: a zöld szakasz bal végpontjától balra, a jobb végponttól jobbra lévő, valamint az alsó ponttól lefelé lévő világosabb tartományt. A bal oldalit viszont dominálja a bal végpont, ahogy az egész félsíkot a háromszög bal oldalától balra. A jobb oldalit, a jobb végpont ugyanígy, az alsó szögtartományt a $\left(\frac{8}{10},-\frac{9}{10},-\frac{9}{10}\right)$ csúcs, a ponttól lefelé található félsíkkal együtt.

Adódik a kérdés, hogy hozzárendelési játékok esetén van-e ilyen példa, azaz találhatóe olyan $\mathcal{I}^{*}$-stabil halmaz, amely nem stabil. A következő állításban belátjuk, hogy ilyen nincsen. 
19. ábra. Egyszerü többségi $\mathcal{I}^{*}$-stabil halmaz 2

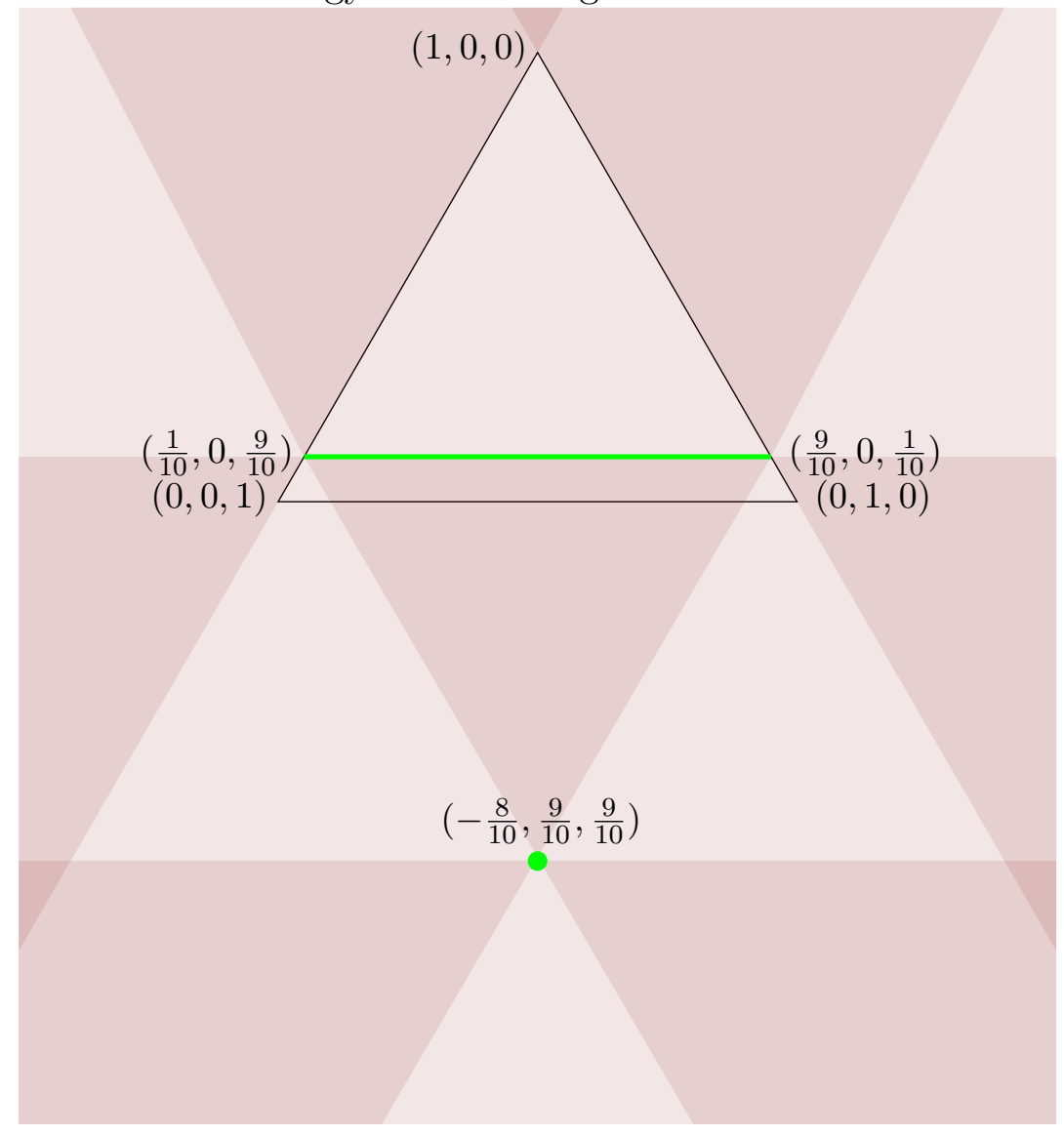

2.2.6. Állítás. Hozzárendelési játékokban minden $\mathcal{I}^{*}$-stabil halmaz részhalmaza az elosztáshalmaznak.

\section{BiZONYÍTÁs.}

Azt fogjuk megmutatni, hogy a stabil halmazokhoz hasonlóan az $\mathcal{I}^{*}$-stabil halmazok is összefüggőek. Ennek a bizonyítása szinte szóról szóra megegyezik a 2.1.2. tételben az összefüggőség bizonyításával. az 1.3.4 állítás (azaz hogy minden stabil halmaz háló) pontosan ugyanúgy múködik az $\mathcal{I}^{*}$-stabil halmazokra is, csak ahol a bizonyításban elosztás szerepel, oda szétosztást, ahol félelosztás oda félszétosztást (olyan kifizetésvektor amely elérhető a nagykoalíció számára) kell helyettesíteni. Tudjuk tehát, hogy minden $\mathcal{I}^{*}$-stabil halmaz háló. a 2.1.1. lemma is teljesül akkor is ha $\mathcal{X} \subseteq \mathcal{I}^{*}$ tartalmazást követelünk meg, mivel az $\mathcal{X}$-beli vektor nem dominálhatja $(\boldsymbol{u} ; \boldsymbol{v})$-t egy egyszemélyes koalíción keresztül, mert akkor dominálná $\left(\boldsymbol{x}^{1} ; \boldsymbol{y}^{1}\right)$-et vagy $\left(\boldsymbol{x}^{2} ; \boldsymbol{y}^{2}\right)$-t is, ellentmondva $\mathcal{X}$ belső stabilitásának. Ha a dominancia vegyespároson keresztül történik, akkor viszont nem számít az alaphalmaz. Innen már tényleg minden ugyanaz, mint a 2.1.2. tételben, az előző lemma segítségével megmutatjuk, hogy bármely két pontja közt léte- 
zik egy harmadik, amiből következik a 2.1.2. lemma segítségével a $\mathcal{I}^{*}$-stabil halmazok összefüggősége.

Az összefüggőségből pedig nagyon könnyen következik, hogy minden $\mathcal{I}^{*}$-stabil halmaz része az elosztáshalmaznak. Tegyük fel, hogy nem így van azaz létezik olyan $\mathcal{V}$ halmaz, amely $\mathcal{I}^{*}$-stabil és létezik $(\boldsymbol{u} ; \boldsymbol{v}) \in \mathcal{V}$ elem, amelyben valamelyik játékos kifizetése negatív. Ekkor $\mathcal{V}$ összefüggösége és a mag nemüressége miatt létezik olyan pontja is $\mathcal{V}$-nek ahol ugyanennek a játékosnak a kifizetése 0, ami nem lehet, mert ez a szétosztás dominálja $(\boldsymbol{u} ; \boldsymbol{v})$-t ellentmondva a belső stabilitásnak.

2.2.7. Következmény. Hozzárendelési játékokban egy $\mathcal{V}$ halmaz pontosan akkor stabil, ha stabil a szétosztáshalmazra nézve, vagyis $\mathcal{I}^{*}$-stabil

Választhatunk természetesen az elosztás- és szétosztáshalmazon kívül más alaphalmazt is. Abban az esetben, ha ez az $\mathcal{X}$ alaphalmaz olyan félelosztásokból áll, amelyek zárt hálót alkotnak (a későbbiekben jellemzően ez egy másik hozzárendelési játék stabil halmaza lesz), akkor a 2.1.2. tételhez hasonló karakterizációját adhatjuk a stabil halmazoknak. Ezt mutatja a következő tétel.

2.2.8. Tétel. Legyen $\mathcal{X} \subseteq \mathcal{I}^{\prime}$ egy összefüggő zárt háló. $A \mathcal{V} \subseteq \mathcal{X}$ halmaz pontosan akkor $\mathcal{X}$-stabil, ha

1. belső stabil,

2. összefüggő,

3. tartalmazza $\mathcal{X}$ eladókra nézve minimális és maximális elemét,

4. tartalmazza bármely két pontja közti részének magját.

A 2.1.2. tétel bizonyítása müködik ebben az esetben is, sőt egyszerúbb is, mivel az alaphalmaz zárt a hálókombinációra, így azok az esetek, amikor vettük két (fél)elosztás hálókombinációját, és az nem volt félelosztás nem állhatnak elö.

Ennek a tételnek a segítségével kapcsolatot teremthetünk különböző játékok stabil halmazai közt, és konstruálhatunk különböző stabil halmazokat. Ehhez elöször lássuk be a következő tranzitivitáshoz hasonló állítást

2.2.9. Következmény. Legyen $A$ és $A^{\prime}$ két azonos méretü, nemnegatív mátrix, amelyekre $A \leq A^{\prime}$ és a maximális párosításaik értéke megegyezik. Ha $\mathcal{V}$ egy stabil halmaz az A-hoz tartozó, és $\mathcal{V}^{\prime}$ egy $\mathcal{V}$-stabil halmaz az $A^{\prime}$-höz tartozó hozzárendelési játékban, akkor $\mathcal{V}^{\prime}$ stabil az $A^{\prime}$-höz tartozó hozzárendelési játékban. 


\section{BIZONYÍTÁs.}

Ellenőrizzük le a stabilitás 4 feltételét: $\mathcal{V}^{\prime}$ belső stabilitása és összefüggősége nem függ az alaphalmaztól, így ez a két tulajdonság következik $\mathcal{V}^{\prime}$ halmaz $\mathcal{V}$-stabilitásából. Mivel $\mathcal{V}$ halmaz stabil, így van olyan pontja, amiben minden a vevőké és egy olyan, amiben minden az eladóké, és ez a halmaz eladókra nézve minimális és maximális pontja, amit $\mathcal{V}^{\prime}$-nek tartalmaznia kell a halmaz $\mathcal{V}$-stabilitása miatt. Tegyük fel, hogy a 4. feltétel nem teljesül, azaz van a $\mathcal{V}^{\prime}$ halmaznak két $\left(\boldsymbol{x}^{1} ; \boldsymbol{y}^{1}\right)$ és $\left(\boldsymbol{x}^{2} ; \boldsymbol{y}^{2}\right)$ pontja és ezek között lévő, $(\boldsymbol{u} ; \boldsymbol{v}) \notin \mathcal{V}^{\prime}$ félelosztás, amit nem dominálható ezen két pont között semmivel az $A^{\prime}$ mátrixhoz tartozó játékban.

- ha $(\boldsymbol{u} ; \boldsymbol{v}) \in \mathcal{V}$, akkor a $\mathcal{V}^{\prime}$ halmaz $\mathcal{V}$-stabilitása miatt létezik $(\boldsymbol{x} ; \boldsymbol{y}) \in \mathcal{V}^{\prime}$, amely dominálja $(\boldsymbol{u} ; \boldsymbol{v})$-t az $A^{\prime}$-höz tartozó játékban. Ebben az esetben 2.1.1. lemma miatt létezik $\mathcal{V}^{\prime}$-nek $\left(\boldsymbol{x}^{1} ; \boldsymbol{y}^{1}\right)$ és $\left(\boldsymbol{x}^{2} ; \boldsymbol{y}^{2}\right)$ közti ilyen pontja is, ami nem más mint $\operatorname{med}\left(\left(\boldsymbol{x}^{1} ; \boldsymbol{y}^{1}\right),(\boldsymbol{x} ; \boldsymbol{y}),\left(\boldsymbol{x}^{2} ; \boldsymbol{y}^{2}\right)\right)$. Ez pedig ellentmond $(\boldsymbol{u} ; \boldsymbol{v})$ választásának.

- ha $(\boldsymbol{u} ; \boldsymbol{v}) \notin \mathcal{V}$, akkor $\mathcal{V}$ halmaz stabilitása és $\left(\boldsymbol{x}^{1} ; \boldsymbol{y}^{1}\right),\left(\boldsymbol{x}^{2} ; \boldsymbol{y}^{2}\right) \in \mathcal{V}^{\prime} \subseteq \mathcal{V}$ miatt létezik olyan félelosztás $\left(\boldsymbol{x}^{1} ; \boldsymbol{y}^{1}\right)$ és $\left(\boldsymbol{x}^{2} ; \boldsymbol{y}^{2}\right)$ között, amely dominálja $(\boldsymbol{u} ; \boldsymbol{v})$-t az $A$-hoz tartozó játékban. Ugyanez az elosztás természetesen dominálja az $A^{\prime}$-höz tartozó játékban is mivel $A^{\prime} \geq A$.

A következő állítás a mag stabilitására vonatkozó 2.2.1. állításnak a módosítása abban az esetben ha az alaphalmaz egy másik játékbeli stabil halmaz.

2.2.10. Következmény. Legyen A és $A^{\prime}$ két azonos méretü, nemnegatív mátrix, amelyekre $A \leq A^{\prime}$ és a maximális párositásaik értéke megegyezik. Ha $\mathcal{V}$ egy stabil halmaz az A-hoz tartozó játékban, akkor a $\mathcal{V}^{\prime}=\mathcal{C}_{A^{\prime}}(\mathcal{V})$ halmaz pontosan akkor stabil az $A^{\prime}$-höz tartozó hozzárendelési játékban ha összefüggö.

\section{BiZONYÍTÁs.}

2.2.9. következmény miatt elég $\mathcal{V}^{\prime}$ halmaz $\mathcal{V}$-stabilitását megmutatni. Mivel $\mathcal{V}$ halmaz háló, így $\mathcal{V}^{\prime}$ halmaz $\mathcal{V}$-stabilitásának eldöntéséhez használható a 2.2.8. tétel. Ennek értelmében $\mathcal{C}_{A^{\prime}}(\mathcal{V})$ halmazra kell belátnunk a tételben szereplö tulajdonságokat az összefüggőség kivételével. A belső stabilitás, valamint, hogy tartalmazza a vevő- és eladóoptimális pontokat a mag definíciójából nyilvánvaló. A 4. tulajdonság bizonyítása hasonló a 2.2.9 következmény bizonyításához, sőt egy kicsit egyszerübb is. Tegyük fel, hogy létezik $\left(\boldsymbol{x}^{1} ; \boldsymbol{y}^{1}\right),\left(\boldsymbol{x}^{2} ; \boldsymbol{y}^{2}\right) \in \mathcal{V}^{\prime}$ és ezek között egy $(\boldsymbol{u} ; \boldsymbol{v}) \in \mathcal{V} \backslash \mathcal{V}^{\prime}$ pont, amelyet nem dominál $\left(\boldsymbol{x}^{1} ; \boldsymbol{y}^{1}\right)$ és $\left(\boldsymbol{x}^{2} ; \boldsymbol{y}^{2}\right)$ közti pontja $\mathcal{V}$-nek az $A^{\prime}$-höz tartozó játékban. Mivel 
$(\boldsymbol{u} ; \boldsymbol{v}) \notin \mathcal{V}^{\prime}=\mathcal{C}_{A^{\prime}}(\mathcal{V})$, ezért létezik olyan $(\boldsymbol{x} ; \boldsymbol{y}) \in \mathcal{V}$ vektor, amely dominálja az $A^{\prime}$ höz tartozó játékban. Ekkor 2.1.1. lemma miatt létezik $\left(\boldsymbol{x}^{1} ; \boldsymbol{y}^{1}\right)$ és $\left(\boldsymbol{x}^{2} ; \boldsymbol{y}^{2}\right)$ közti ilyen pontja is $\mathcal{V}$-nek, ami dominálja $(\boldsymbol{u} ; \boldsymbol{v})$-t, ami ellentmond $(\boldsymbol{u} ; \boldsymbol{v})$ választásának.

Tehát ha van egy hozzárendelési játékban egy stabil halmaz, és a generáló mártrixnak megnöveljük néhány elemét úgy hogy ne változzon a maximális súlyú párosítás, azaz a kiosztandó pénz értéke. Ekkor ha az eredeti stabil halmazból „kidobjuk” a változtatás után dominált elemeket, és az így kapott halmaz összefüggő, akkor stabil halmazt kapunk az új játékban. Kérdés, hogy tudjuk-e valahogy garantálni az összefüggőséget. A következö állításban megmutatjuk, hogy ha csak egyetlen elemet növelünk, akkor az eredeti stabil halmaz új játékbeli magja összefüggő lesz, így stabil az új játékban.

2.2.11. Állítás. Legyen $A$ és $A^{\prime}$ két azonos méretü, nemnegatív mátrix, amelyekre $A \leq$ $A^{\prime}$, maximális párosításaik értéke megegyezik és a két mátrix összesen 1 elemben tér el egymástól. $H a \mathcal{V}$ egy stabil halmaz az A-hoz tartozó játékban, akkor a $\mathcal{V}^{\prime}=\mathcal{C}_{A^{\prime}}(\mathcal{V})$ halmaz stabil az A'-höz tartozó hozzárendelési játékban.

\section{BIZONYÍTÁS.}

2.2.10. következmény miatt elég megmutatnunk, hogy $\mathcal{C}_{A^{\prime}}(\mathcal{V})$ halmaz összefüggö. Legyen az $(i ; j)$ vegyespároshoz tartozó elem, amiben eltér egymástól $A$ és $A^{\prime}$ mátrix. Jelöljük $\mathcal{V}_{(i ; j)}$-vel $\mathcal{V}$ halmaz $(i ; j)$ vegyespáros általi felső burkolóját, azaz legyen $\mathcal{V}_{(i ; j)}=$ $\left\{(\boldsymbol{u} ; \boldsymbol{v}) \in \mathcal{V} \mid \nexists(\boldsymbol{x} ; \boldsymbol{y}) \in \mathcal{V}: x_{i}>u_{i}\right.$ és $\left.y_{j}>v_{j}\right\}$. Ez a halmaz nyilván zárt háló, tartalmazza $\mathcal{V}$ vevő- és eladóoptimális pontját, valamint részhalmaza $\mathcal{V}^{\prime}$-nek, mivel $\mathcal{V}$ elemeiről az $A$ mátrixhoz tartozó játékbeli belső stabilitása miatt tudjuk, hogy az $(i ; j)$ vegyespárost leszámítva $A^{\prime}$-höz tartozó játékban sem dominálják egymást az elemei. Az $(i ; j)$ vegyespároson keresztül pedig a definíciója miatt nem dominálhatja $\mathcal{V}$ beli elem az $A^{\prime}$ höz tartozó játékban, mivel $\mathcal{V}$ egyik eleme sem előnyösebb az $(i ; j)$ vegyespáros mindkét tagja számára. az 1.3.7. állítás miatt elegendő megmutatnunk, hogy létezik $\mathcal{V}^{\prime}$-ben a halmazbeli görbe, amely összeköti a vevő- és eladóoptimális pontjait. Mivel $\mathcal{V}_{(i ; j)}$ részhalmaza $\mathcal{V}^{\prime}$-nek és tartalmazza ezen két pontot ezért elég megmutatnunk, hogy $\mathcal{V}_{(i ; j)}$ bármely két pontját összeköti $\mathcal{V}_{(i ; j)}$ beli görbe. Ehhez vegyünk tetszőleges két $\left(\boldsymbol{x}^{1} ; \boldsymbol{y}^{1}\right)$ és $\left(\boldsymbol{x}^{2} ; \boldsymbol{y}^{2}\right)$ elemét $\mathcal{V}_{(i ; j)}$-nek.

- Ha $x_{i}^{1}=x_{i}^{2}$ és $y_{j}^{1}=y_{j}^{2}$, akkor mivel $\mathcal{V}$ stabil halmaz volt, így volt benne ezen két pontot összekötő monoton görbe, amely görbe részhalmaza $\mathcal{V}_{(i ; j)}$-nek is.

- Ha $x_{i}^{1} \neq x_{i}^{2}$ vagy $y_{j}^{1} \neq y_{j}^{2}$, akkor szimmetria miatt feltehető, hogy az első áll fenn. Legyen $x$ egy szigorúan $x_{i}^{1}$ és $x_{i}^{2}$ közti szám. $\mathcal{V}$ összefüggősége miatt létezik $\left(\boldsymbol{x}^{3} ; \boldsymbol{y}^{3}\right) \in \mathcal{V}$, amelyre $x_{i}^{3}=x$ és az ilyen pontok közül a $y_{j}^{3}$ a lehetö legnagyobb 
érték. $y_{j}^{3}$-ről tudjuk, hogy $y_{j}^{1}$ és $y_{j}^{2}$ között van (egyenlőséget is megengedve). Ha nem így lenne, akkor mivel van $\left(\boldsymbol{x}^{3} ; \boldsymbol{y}^{3}\right)$ pontot a vevő- és eladóoptimális ponttal összekötő monoton görbe, ez ellentmondana $\left(\boldsymbol{x}^{1} ; \boldsymbol{y}^{1}\right) \in \mathcal{V}_{(i ; j)}$ vagy $\left(\boldsymbol{x}^{2} ; \boldsymbol{y}^{2}\right) \in \mathcal{V}_{(i ; j)}$ feltételnek. Ekkor viszont $\left(\boldsymbol{x}^{4} ; \boldsymbol{y}^{4}\right)=\operatorname{med}\left(\left(\boldsymbol{x}^{1} ; \boldsymbol{y}^{1}\right),\left(\boldsymbol{x}^{3} ; \boldsymbol{y}^{3}\right),\left(\boldsymbol{x}^{2} ; \boldsymbol{y}^{2}\right)\right)$-ról tudjuk, hogy eleme $\mathcal{V}$-nek, mert $\mathcal{V}$ háló. Mivel az $(i ; j)$ vegyespáros kifizetése $\left(\boldsymbol{x}^{4} ; \boldsymbol{y}^{4}\right)$ ben ugyanannyi mint $\left(\boldsymbol{x}^{3} ; \boldsymbol{y}^{3}\right)$-ban, így $\left(\boldsymbol{x}^{4} ; \boldsymbol{y}^{4}\right) \in \mathcal{V}_{(i ; j)}$, és különbözik $\left(\boldsymbol{x}^{1} ; \boldsymbol{y}^{1}\right)$-től valamint $\left(\boldsymbol{x}^{2} ; \boldsymbol{y}^{2}\right)$-töl.

Mindkét esetben találtunk egy harmadik pontot a két tetszőlegesen választott pontunk között.Ami szintén $\mathcal{V}_{(i ; j)}$-ben van, így 2.1.2. lemma miatt $\mathcal{V}_{(i ; j)}$ halmaz összefüggő, tehát $\mathcal{V}^{\prime}$ is.

Ha tehát egyszerre egy elemet változtatunk a mátrixban, akkor az eredeti stabil halmaz új játékbeli magját véve, az új játékbeli stabil halmazt kapunk. Ezt felhasználva már könnyen tudunk módszert adni stabil halmaz készítésére akkor is, ha egyszerre több elem nő és természetesen a maximális súlyú párosítás változatlan marad. Egyszerủen egyenként kell növelni az elemeket, és minden egyes növelés után kell venni az új játékban az előző stabil halmaz magját.

Ezt az állítást felhasználva kaptunk egy új bizonyítást arra, hogy minden hozzárendelési játékban létezik stabil halmaz:

\subsubsection{Következmény. Minden hozzárendelési játékban van stabil halmaz.}

\section{BIZONYÍTÁS.}

Vegyünk egy tetszőleges $A$ nemnegatív mátrixot. Először 0-zuk le az összes elemét a maximális párosításon kívül. Ha több ilyen is van, akkor ezek közül válasszunk ki egyet és az ezen kívüli elemek helyére írjunk 0-kat. Ennek a diagonális mátrixnak a magja, ami éppen a principal sectione stabil, mivel a maximális párosítás minden eleme sorés oszlopmaximum is egyben. Innentől kezdve minden lépésben változtassuk vissza az aktuális mátrixunk egy elemét $A$ megfelelő elemére és vegyük az előző stabil halmaz magját az új játékban. Ez a halmaz 2.2.11. következmény miatt stabil az új játékban. Ezzel a módszerrel véges sok lépésben eljutunk az eredeti játékhoz és egy hozzá tartozó stabil halmazhoz.

A stabil halmaz konstruálása során láttuk, hogy mindegy volt, milyen sorrendben növeltük vissza a mátrix elemeit, sőt azt is megtehetjük, hogy több lépésben növelünk. például ha $a_{i j}$ elem eredetileg 2 volt, akkor 0-ról csak 1-re növeljük elöször, majd növelgetjük a többi elemet, majd néhány lépéssel később növeljük meg 1-ről 2-re. Kérdés, hogy számít-e a sorrend, különböző halmazokat kapunk-e ha máshogy növelünk a kiinduló diagonális mátrixból. Erre a kérdésre a válasz nem, a sorrend nem számít. Vegyük 
észre, hogy a principal section magja, azaz a $\mathcal{C B}_{A}$ halmaz minden lépés után része az aktuális stabil halmaznak. $\mathcal{C B}_{A}$ tehát részhalmaza a végén kapott stabil halmaznak, 1.4.1. tételben láttuk, hogy $\mathcal{C B}_{A}$ halmaz stabil. Mivel egy stabil halmaz nem lehet szigorú részhalmaza egy másik stabil halmaznak azt kaptuk, hogy sorrendtől függetlenül ha egy (maximális súlyú párosításhoz tartozó) diagonális mátrixból indulunk ki, akkor végül a principal section magját a $\mathcal{C B}_{A}$ halmazt kapjuk.

Ezt a fajta konstrukciót a 4. példában szereplő számpéldán keresztül mutatjuk meg. A játékot generáló mátrix ott az $A=\left(\begin{array}{ll}7 & 3 \\ 5 & 4\end{array}\right)$ volt. A maximális súlyú párosítás a fóátlóban szerepel. Először nullázzuk le a másik két elemet, így megkapjuk az $A_{1}=$ $\left(\begin{array}{ll}7 & 0 \\ 0 & 4\end{array}\right)$

mátrixot. Ennek a magja megegyezik a principal sectionével, ami az $u_{1}+v_{1}=$ $7 ; u_{2}+v_{2}=4 ; u_{1}+u_{2}+v_{1}+v_{2}=11 ; u_{1}, u_{2} ; v_{1} ; v_{2} \geq 0$ egyenletek és egyenlőtlenségek által meghatározott téglalap, ahol $\boldsymbol{u}$ vektorral az eladók (a sorokhoz tartozó játékosok), $\boldsymbol{v}$ vektorral pedig a vevők (az oszlopokhoz tartozó játékosok) kifizetését jelöltük. Ábrázoljuk ezt az $u_{1}+v_{1}=7 ; u_{2}+v_{2}=4$ síkon, ahogy a 4 . példában is tettük. Ez látható a 20, ábrán.

Növeljük vissza az első sor második elemét 3-ra, így megkapjuk az $A_{2}=\left(\begin{array}{ll}7 & 3 \\ 0 & 4\end{array}\right)$ mátrixot. Vegyük az elöző téglalap magját az új játékban. Az ábrán ez azt jelenti, hogy le kell vágnunk a bal felső $(0 ; 1),(0 ; 4)$ és $(3,4)$ csúcsú háromszöget, mivel a $(0 ; 1)$ és $(3 ; 4)$ pontokat összekötő szakasz dominálja, ahogy a 21. ábrán is látható. Ez a zöld halmaz stabil az $A_{2}$ mátrixhoz tartozó játékban.

Végül növeljük vissza a második sor első elemét 5-re, és vegyük az előző lépésben kapott levágott sarkú téglalap magját. Ekkor jobb oldalról kell levágnunk a $(2 ; 0),(6 ; 4),(7 ; 4),(7 ; 0)$ csúcsú trapézt, mert ezt dominálja a $(2 ; 0),(6 ; 4)$ szakasz. Kivéve a trapéz felső $(6 ; 4)$ és $(7 ; 4)$ végpontú alapját, melyet nem dominál. Az így kapott ötszög kiegészítve a jobb felső szakasszal stabil az eredeti játékban.

Így a harmadik lépésben megkaptuk azt a stabil halmazt, amelyet a 4 példában is láttunk. A két eladós két vevős példában ez elég egyszerűnek látszik, mivel a két dominancia „egymástól független”, amikor levágjuk a bal felső sarkot az nem befolyásolja a jobb alsót és fordítva. Ha azonban megnézzük a 3 , példát ott látszik, hogy mi lehetne a probléma. Ha a második sor harmadik elemében lévő 1-est növeljük vissza utoljára, akkor az nem változtat semmit, mert a mag mindkét esetben ugyanaz a halmaz. Ha viszont azt növeljük meg először, akkor levágunk egy részt és lehet, hogy ennek a levágott résznek a későbbi növeléseknél szerepe lett volna. Lehet, hogy csak emiatt a rész miatt 
20. ábra. Konstrukció 1 . lépés

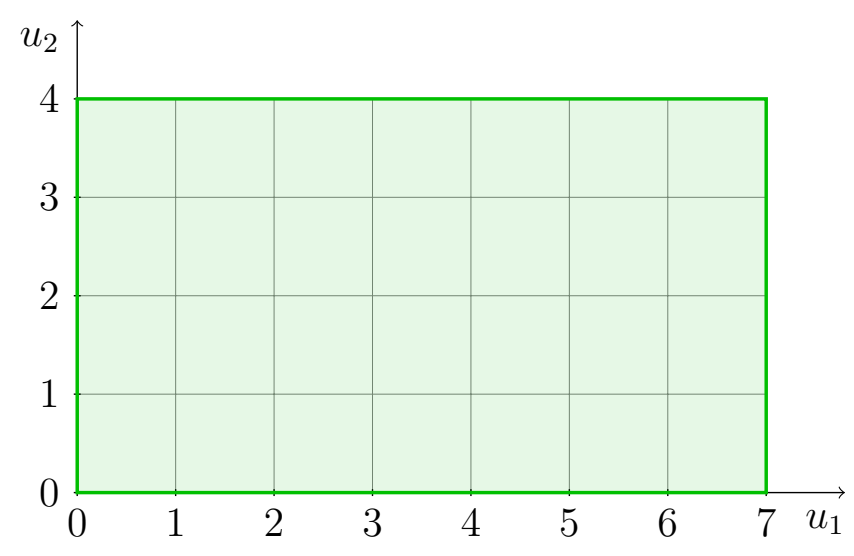

21. ábra. Konstrukció 2. lépés

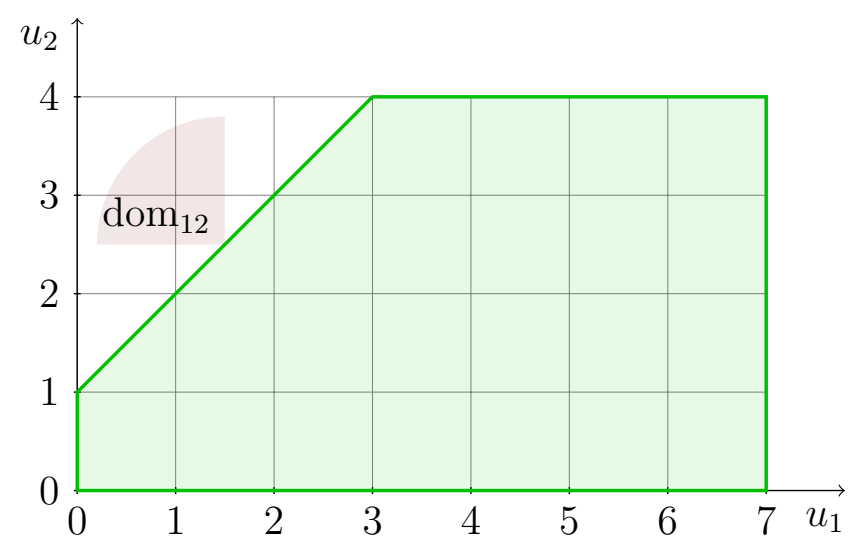

kell levágnunk egy másik részt, és végül egy másik halmazt kapunk, de mint láttuk ez nem fordulhat elö.

a 2.2.11. állítás nem csak arra használható, hogy egy már eddig is ismert stabil halmazt megkapjunk máshogy is. Ha nem a diagonális mátrixból és a principal sectionből indulunk ki, akkor konstruálhatunk más stabil halmazokat is. a 9, példában láttunk egy 2 eladós 2 vevős esetben olyan stabil halmazt, amely nem $\mathcal{C B}$ típusú. A magot nem a principal sectinbeli szakasszal egészítettük ki, hanem egy másikkal, amely az eladóoptimális csúcsot kötötte össze egy olyan ponttal, ahol minden vevő kifizetése 0. Megmutatható a példához hasonlóan, hogy a 2 eladós 2 vevős esetben, ha a játék magjának eladóoptimális pontja pozitív kifizetést biztosít valamelyik vevőnek, akkor a magot kiegészítjük egy tetszőleges monoton görbével, amelynek egyik vége a mag eladóoptimális pontja, a másik végén pedig minden vevő kifizetése 0 , akkor stabil halmazt kapunk (ha a vevőoptimális pontban valamely eladó kifizetése 0 , akkor ugyanezt a má- 
22. ábra. Konstrukció 3. lépés

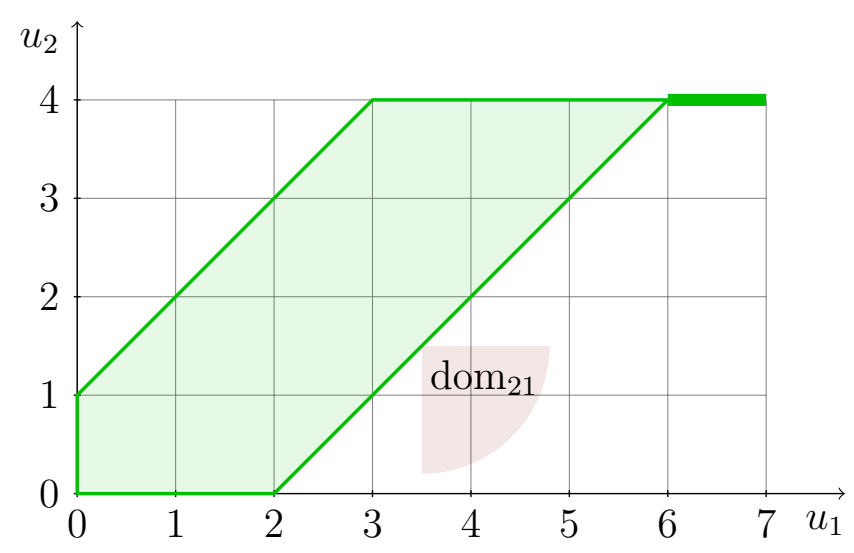

sik oldalon is meg kell tennünk. A példában tehát nem csak az $(1,2 ; 0,1)$ és $(2,2 ; 0,0)$ pontokat összekötő szakasszal egészithettük volna ki a magot, hanem tetszőleges, az $(1,2 ; 0,1)$ pontot egy $(x, y ; 0,0)$ ponttal összekötő, az eladók kifizetésében monoton növő, a vevőkében monoton csökkenő elosztáshalmazbeli görbével. Ez azt jelenti, hogy a 2 eladós-2 vevős esetben ha a mag nem stabil, akkor végtelen sok stabil halmaz van, és ezek metszete a játék magja. Ha a mag stabil, akkor ilyen probléma nincs, tudjuk hogy az az egyetlen stabil halmaz. a 2.2.11. állítást felhasználva beláthatjuk a következő állítást.

2.2.13. Állítás. Ha egy hozzárendelési játék magja nem stabil, akkor végtelen sok stabil halmazzal rendelkezik, melyek metszete a játék magja

\section{BiZONYÍTÁs.}

Ha a játék magja nem stabil, az az 1.2.1. tétel szerint azt jelenti, hogy a mátrix nem fóátlódomináns, azaz van olyan fóátlón kívüli eleme, amely szigorúan nagyobb, mint ugyanabban a sorban vagy oszlopban lévő fóátlóbeli elem. Feltehető, hogy ez az elem a mátrix első sorának második eleme (átrendezéssel ez mindig elérhetö). Nullázzuk le a fóátlón valamint az ezen az elemen kívüli összes elemet. Ebben a „majdnem diagonális” mátrixban a $2+2$-es esetet felhasználva könnyen tudunk végtelen sok különbözö stabil halmazt megadni. Hozzárendelési játékok esetén könnyen látszik, hogy ha a generáló mátrix blokkdiagonális, akkor ha minden blokkból veszünk $1-1$ stabil halmazt és képezzük ezeknek a direktszorzatát, akkor az eredeti játékban is stabil halmazt kapunk. Vegyünk egy tetszőleges elosztásvektort, és szorítsuk meg az egyes blokkokra. Ha a vektort nem a direktszorzatból vettük, akkor valamelyik megszorítása nem eleme a megfelelö stabil halmaznak, ez azt jelenti, hogy a megfelelő játékban a stabil halmaz 
valamely eleme dominálja a megszorított vektort. Ugyanezen koalíción keresztül a a domináló vektor tetszőleges ősképe is dominálja az eredeti vektort.

Ebből a direktszorzatból kiindulva 2.2.12, következmény bizonyításához hasonlóan, az elemek egyenkénti visszanövelésével, és az addigi stabil halmaz új játékbeli magjának vételével kaphatunk stabil halmazt az eredeti játékban. Ha eredetileg a bal felső $2 \times 2-$ es részen különböző stabil halmazt vettünk, akkor a végén is különböző eredményeket kapunk, mivel a stabil halmaz összefüggősége miatt, ha a végül kapott halmazt megszorítjuk a bal felső $2+2$-es részre, akkor a magot kiegészítő monoton görbék ugyanazok, mint amiket a $2+2$-es részen eredetileg választottunk.

Kaptunk tehát végtelen sok különböző stabil halmazt. Most megmutatjuk, hogy ezek metszete tényleg a mag. Mivel a mag részhalmaza az összes stabil halmaznak tudjuk, hogy részhalmaza a stabil halmazok metszetének. A fenti konstrukcióból kapott stabil halmazokat ha megszorítjuk $2+2$-es blokkok játékosaira, akkor a megszorításon vett metszet vevő- és eladóoptimális pontja a magnak a vevő- és eladóoptimális pontjai voltak. Ebből következik, hogy az eredeti halmazban is a metszet vevő- és eladóoptimáis pontjai, a mag vevő- és eladóoptimális pontjai. Ezen két pont között viszont minden stabil halmazban csak a mag található.

Már korábban is említettük, hogy a TU játékokra általában nem igaz ez az állítás. Lucas (1968b) mutatott egy 5 személyes példát, amelynek csak egy stabil halmaza van, és az szigorúan nagyobb a magnál.

Ez a tranzitivitás-szerü tulajdonság nem csak arra jó, hogy több stabil halmazt is tudjunk készíteni, hanem akár gyakorlati példákban a stabil halmaz kialakulását is le lehet írni egyes esetekben. Mint már korábban említettük egy stabil halmazt tekinthetünk egyfajta normaként, úgy mint a társadalom számára jónak tartott elosztások. Ezek egymással nincsenek ellentmondásban (nem dominálják egymást, belső stabilitás), és minden „rossz” elosztás levezetheto belőlük (minden halmazon kívüli elemet dominál a halmaz valamely eleme, külső stabilitás). Arról azonban, hogy hogy alakul ki egy ilyen norma nem volt szó, vagy ha több is van, akkor miért pont az egyik alakul ki, miért nem valamelyik másik. A fent leírt konstrukcióhoz a következő magyarázat adható. Tegyük fel, hogy már kialakult valamilyen norma, megvannak a jónak gondolt elosztások, és egyszer az egyik páros értéke valamilyen okból megnő. Ez lehet például valamilyen technológiai fejlődés következménye, esetleg a páros eddig csak valamilyen oknál fogva nem vallotta be, hogy ők ketten többet is el tudnának érni. Ebben az esetben elromolhat a belső stabilitás, elképzelhető, hogy az egyik eddig jónak gondolt elosztással szemben valakik ki tudnak kényszeríteni egy másik jó elosztást. A fenti 
konstrukció azt állítja, hogy ha a halmazunkból kihagyjuk az újonnan dominált elosztásokat, és innentől azokat is rossznak tekintjük, akkor a maradék halmaz továbbra is stabil lesz.

A következő fejezetben a hozzárendelési játékok egy speciális osztályán meg fogjuk adni az összes stabil halmazt. 


\section{1-eladós eset}

\subsection{Stabil halmazok megadása}

Ebben a részben a hozzárendelési játékok egy speciális esetét vizsgáljuk, amikor csak 1 eladó van. Az ilyen hozzárendelési játékokban a 2.1.2. karakterizációnál szebben, egyszerübben is le lehet írni a stabil halmazokat (Bednay, 2014). A stabil halmazok e fejezetbeli megadását is elég könnyen le lehetne vezetni a 2.1.2. tételbeli karakterizáció következményeként, azonban ha így tennénk ágyúval lőnénk verébre. Egy eladó esetén sokkal egyszerübben megkaphatjuk ezeket az eredményeket, és a bizonyítás is jobban követhető, és sokat elárul erről a speciális esetről. A fejezet során a Bednay (2014) cikkben található leírást fogjuk követni, néhány apró eltéréssel. Ezeknek az eltéréseknek az oka, hogy az előző fejezetekben például a háló tulajdonsággal kapcsolatban már beláttunk egyszerű lemmákat, amelyekre hivatkozni fogunk. Ugyan ezek általánosabb környezetben is igazak, de a bizonyításuk elég egyszerü volt, nem lenne értelme körülbelül ugyanannyi munkával még egyszer megmutatni ezeket csak az egy-eladós esetre.

Ha csak egy eladónk van, akkor a játékot meghatározó mátrixnak csak 1 sora van, így nyugodtan tekinthetünk rá nemnegatív vektorként is. A jelölések egyszerüsítése végett feltesszük, hogy az 1-eladós $n$-vevős hozzárendelési játékhoz tartozó mátrix elemei monoton csökkennek, azaz $a_{1} \geq a_{2} \geq \cdots \geq a_{n} \geq 0$. A nagykoalíció értéke ekkor természetesen $a_{1}$ lesz. Technikai okok miatt definiáljuk az $a_{n+1}=0$ értéket. Ennek csak a fejezet végén, a határhozzájárulás vektorokkal való kapcsolatnál lesz szerepe. Mivel csak egy eladónk van, így egy vegyespárost meghatároz a vevő tagja, ezért az eladóból és $i$ vevőből álló vegyespároson keresztüli dominanciát $\operatorname{dom}_{i}$-vel fogjuk jelölni, tehát az általános hozzárendelési játékokhoz képest elhagyjuk az eladóra utaló indexet.

A stabil halmazok megadásához szükségünk lesz az elosztáshalmaznak azon részhalmazára, amelyben minden olyan vegyespáros számára elérhető, amelyben a vevő kifizetése pozitív. Ezt a halmazt fogjuk $\mathcal{X}$-szel jelölni.

\subsubsection{Definíció.}

$$
\mathcal{X}=\left\{(u, \boldsymbol{v}) \in \mathcal{I} \quad \mid \forall 1 \leq i \leq n: v_{i}=0 \text { vagy } u+v_{i} \leq a_{i}\right\}
$$

3.1.2. Definíció. Azt mondjuk, hogy $\mathcal{V}$ egy „X-beli $\left[0, a_{1}\right]$ folytonos, monoton görbe” ha

$\exists f:\left[0, a_{1}\right] \rightarrow \mathbb{R}^{n}$ folytonos, monoton csökkenő függvény, amire graph $(f)=\mathcal{V} \subseteq \mathcal{X}$

3.1.3. Állítás. Egy $\mathcal{V}$ halmaz akkor és csak akkor stabil, ha $\mathcal{V}$ egy „X-beli $\left[0, a_{1}\right]$ folytonos monoton görbe" 


\section{BizonYíTÁs.}

- Ezek stabilak: legyen $\mathcal{V}$ egy ilyen halmaz.

- Belső stabilitás: a monotonitás miatt triviális, mivel legyen $(u ; \boldsymbol{v}),\left(u^{\prime} ; \boldsymbol{v}^{\prime}\right) \in$ $\mathcal{V}$. Ha $u>u^{\prime}$, akkor $\boldsymbol{v} \leq \boldsymbol{v}^{\prime}$, így nem járhat egyszerre jobban egy vevo és az eladó is.

- Külső stabilitás: legyen $(u, \boldsymbol{v}) \in \mathcal{I} \backslash \mathcal{V}$, ekkor $0 \leq u<a_{1}$ teljesül, mivel $u \geq a_{1}$ csak akkor lehetne ha $\boldsymbol{v}=\mathbf{0}$ mivel $(u ; \boldsymbol{v})$-ről tudjuk, hogy elosztás, az $\left(a_{1} ; \mathbf{0}\right)$ vektor viszont biztosan eleme $\mathcal{V}$-nek.

Tudjuk tehát, hogy $0 \leq u<a_{1}$. Ekkor találunk olyan $\left(u^{\prime}, \boldsymbol{v}^{\prime}\right) \in \mathcal{V}$ elosztást, amire $u<u^{\prime}$ és $v_{i}<v_{i}^{\prime}$ teljesül, mivel tegyük fel hogy nincs ilyen, ekkor $\left(u^{m} ; v^{m}\right)=\left(u+\frac{1}{m} ; f\left(u+\frac{1}{m}\right)\right)$ sem ilyen semmilyen $m \in \mathbb{N}$-re (ez végtelen sok $m$-re lesz elosztás) tehát $f\left(u+\frac{1}{m}\right) \leq \boldsymbol{v}$, ekkor $\lim _{m \rightarrow \infty}\left(u^{m} ; \boldsymbol{v}^{m}\right)=(u ; \boldsymbol{v})$. $f$ folytonossága miatt $(u ; \boldsymbol{v}) \in \mathcal{V}$, ami nem lehet. Ha viszont találunk ilyen $\left(u^{\prime} ; \boldsymbol{v}^{\prime}\right)$ párt, akkor $\left(u^{\prime} ; \boldsymbol{v}^{\prime}\right) \operatorname{dom}_{i}(u ; \boldsymbol{v})$.

- Csak ilyen stabilak vannak: 1.3.4. állításból (minden stabil halmaz háló) könnyen következik $\mathcal{V}$ monotonitása. Tegyük fel, hogy létezik $\left(u^{1} ; \boldsymbol{v}^{1}\right),\left(u^{2} ; \boldsymbol{v}^{2}\right) \in \mathcal{V}$, amelyekre $u^{1} \leq u^{2}$ és $v_{i}^{1}<v_{i}^{2}$ valamely $i$ vevőre. Ennek a két vektornak egyik hálókombinációja sem lesz elosztás (így nem lehet eleme a stabil halmaznak sem), mert $\left(u^{1} \wedge u^{2} ; \boldsymbol{v}^{1} \vee \boldsymbol{v}^{2}\right)=\left(u_{1} ; \boldsymbol{v}^{1} \vee \boldsymbol{v}^{2}\right)$. A vevők összkifizetése ebben a vektorban viszont szigorúan nagyobb, mint $\boldsymbol{v}^{1}$-ben. Ezzel ellentmondásra jutottunk, azaz minden $\mathcal{V}$ stabil halmaz monoton. 2.1.2. tétel miatt $\mathcal{V}$ összefüggö, és van egy olyan pontja, melyben az eladó- és egy olyan ahol az összes vevő kifizetése 0 . A $\mathcal{V} \subseteq \mathcal{X}$ tartalmazást kell csak megmutatnunk. Tegyük fel, hogy létezik $(u ; \boldsymbol{v}) \in \mathcal{V}$ az $i$ vevőre $v_{i}>0$ és $u+v_{i}>a_{i}$. Csökkentsük le $v_{i}$ értékét $\left|a_{i}-u\right|_{+}$-re, ahol $|x|_{+}$az $x$ pozitív részét azaz 0 és $x$ maximumát jelenti. Ezzel egy szigorú félelosztást kaptunk. 1.1.9. állítás miatt létezik olyan eleme $\mathcal{V}$-nek, amely dominálja ezt a vektort. Ez a dominancia nem történhet az $i$ játékost tartalmazó koalíción keresztül, mert ez a páros együtt legalább annyit kap, amennyi az értékük, más vegyespároson keresztül sem történhet, mert akkor a domináló vektor dominálná $(u ; \boldsymbol{v})$-t is ami ellentmond $\mathcal{V}$ belső stabilitásának.

$\mathcal{X}$ halmaz jellemzően nem egyezik meg a stabil halmazok uniójával, van olyan pontja, amelyből nem tudunk monoton görbével eljutni abba a pontba, ahol az összes vevő vagy 
az eladó kifizetése 0 anélkül, hogy kilépnénk az $\mathcal{X}$ halmazból. Ezt láthatjuk a következő példában is.

11. Példa. Legyen $A=[10,9,7]$ és vegyük a $(5 ; 0,4,1)$ elosztást. Ez nyilván eleme a $\mathcal{X}$ halmaznak, mivel minden vegyespáros, ahol a vevö kifizetése pozitív legfeljebb annyit kap, amennyi az értékük. Tudjuk viszont hogy $\mathcal{X}$-nek egyetlen olyan eleme van, amelyben az eladó kifizetése 9 , ami a $(9 ; 1,0,0)$ elosztás. Ezt a két vektort viszont nem köti össze az eladó kifizetésében monoton növő a vevőkében monoton csökkenő görbe, tehát az $(5 ; 0,4,1)$ vektor nem eleme egyetlen stabil halmaznak sem. Ez könnyen látszott volna abból is, hogy a $(9 ; 1,0,0)$ vektor eleme a magnak, igy biztos része minden stabil halmaznak, viszont az $(5 ; 0,4,1)$ vektorral vett hálókombinációi nem elosztásvektorok.

A probléma abból adódott, hogy a második és a harmadik vevő külön-külön még nem, de együtt túl sokat kapott, többet mint az eladóval együtt a hármukból álló koalíció értéke. Az ilyen vektorokat zárjuk ki a következő halmazban.

\subsubsection{Definíció.}

$$
\mathcal{U}=\left\{(u, \boldsymbol{v}) \in \mathbb{R}_{+} \times \mathbb{R}_{+}^{n}: u+\sum_{i=1}^{n} v_{i}=a_{1}, \forall k: \sum_{j=k}^{n} v_{j} \leq\left|a_{k}-u\right|_{+}\right\}
$$

\subsection{5. Állítás. $\mathcal{U} \subseteq \mathcal{X}$}

\section{BIZONYÍTÁS.}

Legyen $(u, \boldsymbol{v}) \in \mathcal{U}$ azt kell belátnunk, hogy $\forall 1 \leq i \leq n$-re $v_{i}=0$ vagy $u+v_{i} \leq a_{i}$. Tegyük fel, hogy ez nem igaz, azaz $\exists i: v_{i}>0$ és $u+v_{i}>a_{i}$, de ekkor $\sum_{j=i}^{n} v_{j} \geq v_{i}>$ $a_{i}-u$ és mivel $v_{i}>0$, így $\sum_{j=i}^{n} v_{j}>\left|a_{i}-u\right|_{+}$, ami nem lehet, mert feltettük, hogy $(u, \boldsymbol{v}) \in \mathcal{U}$

Megmutatjuk, hogy $\mathcal{X}$ halmazt elég volt ennyire leszűkíteni, $\mathcal{U}$ halmaz a stabil halmazok uniója.

\subsection{6. Állítás.}

$$
\mathcal{U}=\bigcup_{\mathcal{V} \text { stabil }} \mathcal{V}
$$

BizonyítÁs.

$$
\mathcal{U} \supseteq \bigcup_{\mathcal{V} \text { stabil }} \mathcal{V}
$$


Tegyük fel, hogy nem, ekkor $\exists \mathcal{V}$ és $(u, \boldsymbol{v}) \in \mathcal{V}$, amire $(u, \boldsymbol{v}) \in \mathcal{X} \backslash \mathcal{U}$, azaz $\exists k$ : $\sum_{j=k}^{n} v_{j}>\left|a_{k}-u\right|_{+}$. Legyen az $\left(u^{\prime}, \boldsymbol{v}^{\prime}\right)$ a $\mathcal{V}$ halmaznak az a pontja amelyikre $u^{\prime}=a_{k}$, ekkor $v_{k}^{\prime}=v_{k-1}^{\prime}=\cdots=v_{n}^{\prime}=0$ kell, hogy teljesüljön $\left(u^{\prime}, \boldsymbol{v}^{\prime}\right) \in \mathcal{X}$ miatt. Két lehetőség van:

1. $u^{\prime}=a_{k}<u$, akkor a monotonitás miatt $\boldsymbol{v}^{\prime} \geq \boldsymbol{v} \geq 0 \Rightarrow v_{k}=v_{k+1}=v_{n}=0$, de ekkor nem lehetett $\sum_{j=k}^{n} v_{j}=0>\left|a_{k}-u\right|_{+}$

2. $u^{\prime} \geq u$ akkor $\left|a_{k}-u\right|_{+}=a_{k}-u$, tehát $\sum_{j=k}^{n} v_{j}>a_{k}-u$, de ez megint nem lehet, mert $u$-t $a_{k}-u$-val kell növelni, hogy $u^{\prime}$-t kapjunk, de $v$-nek a $k$ utáni koordinátáit összesen többel kell csökkenteni, hogy mind 0 legyen.

$$
\mathcal{U} \subseteq \bigcup_{\mathcal{V} \text { stabil }} \mathcal{V}
$$

Legyen $(u, \boldsymbol{v}) \in \mathcal{U}$, ekkor megadunk egy $\mathcal{V}$ stabil halmazt amire $(u, \boldsymbol{v}) \in \mathcal{V}$ :

1. ha $u^{\prime}<u$, akkor legyen $v^{\prime}=\left(v_{1}+u^{\prime}-u, v_{2}, v_{3}, \ldots, v_{n}\right)$ természetesen $\left(u^{\prime}, \boldsymbol{v}^{\prime}\right) \in \mathcal{X}$ mivel $u^{\prime}+v_{i}^{\prime} \leq u+v_{i} \leq a_{i}$

2. ha $u^{\prime}>u$, akkor ha $u^{\prime}-u=v_{n}+v_{n-1}+\cdots+v_{k+1}+x$, ahol $0 \leq x \leq v_{k}$, akkor legyen $v^{\prime}=\left(v_{1}, v_{2}, \ldots, v_{k-1}, v_{k}-x, 0,0, \ldots, 0\right)\left(u^{\prime}, \boldsymbol{v}^{\prime}\right) \in \mathcal{V}$, mivel ha $v_{i}^{\prime}>0$, akkor $u^{\prime}+v_{i} \leq u+\sum_{j=i}^{n} v_{j} \leq a_{i}$ mert $v_{i}^{\prime}>0 \Rightarrow v_{i}>0 \Rightarrow \sum_{j=i}^{n} v_{j}>0 \Rightarrow \sum_{j=i}^{n} v_{j} \leq a_{i}-u$

Az így kapott görbe monotonitása és folytonossága a konstrukció miatt triviális.

Ez azt jeleni, hogy adott volt az $(u, \boldsymbol{v})$ elosztás, és ebből úgy konstruáltuk meg a görbét, hogy amikor $u$-t csökkentettük, akkor az így kapott összeget az első vevő kapta, u növekedését pedig elöször a legkisebb, majd a második legkisebb ... végül a legnagyobb értékelésű vevő fizette.

Ha ezt a helyzetet úgy képzeljük, mint egy igazi piaci helyzetet, akkor a legnagyobb értékelésű vevő el tud érni minden magbeli elosztást, mert a többiek nem tudnak rálicitálni. Olcsóbban is megveheti az árut valamilyen $p$ áron, de ehhez meg kell egyeznie a többi vevővel, hogy senki ne ígérjen fölé. Cserébe valamennyit át kell adnia a hasznából a többieknek. Egy stabil halmaz, pont ilyen ajánlatok összessége: egy $(p, f(p))$ függvény $f(p)$ azt mutatja meg, hogy ha senki nem ígér $p$ fölé, akkor a megmaradó $a_{1}-p$ pénz hogy oszlik el a vevők közt. Ennek az elosztásnak a konkrét formáit vizsgálja Schotter (1974) különböző aukciós mechanizmusok esetén. A görbének azért kell az $\mathcal{U}$ halmazban lennie, mert $\sum_{i=k}^{n} f_{i}(p)$ azt mutatja meg mennyit ad át az $i$-edik vevönek és az utána következőknek, de ha velük egyáltalán nem egyezkedne akkor is meg 
tudná venni az árut $a_{i}$ áron, tehát ők csak annyi hasznot hoznak amennyivel kisebb az ár $a_{i}$-nél. Ezért kell, hogy $\sum_{i=k}^{n} f_{i}(p) \leq\left|a_{i}-p\right|_{+}$fennálljon. Egy eladó esetén a külső stabilitás jelentése is könnyebben látszik. A legnagyobb vevő felajánlott mindenkinek egy összeget, hogy ne licitáljanak egy $p$ ár fölé, de lehet, hogy valamelyik vevő meggondolja magát, és megegyezik az eladóval egy mindkettőjük számára előnyösebb üzletben (ez egy olyan elosztáshoz vezet, ami dominálja a stabil halmazbelit). A külső stabilitás tulajdonság pont azt mondja, hogy ilyenkor az első vevő vissza tud vágni egy másik elosztással, ami benne van a stabil halmazban, és dominálja a halmazon kívüli elosztást, azaz fel tud ajánlani az eladónak egy harmadik üzletet, amit az örömmel el is fog fogadni, és így visszakerülnek a stabil halmazba. A monotonitás miatt ebben az a vevő, aki el akart térni biztos nem jár jobban, mint az eredetiben, így senkinek nem éri meg eltérnie a halmazbeli elosztásoktól, mert ez úgyis csak rövid ideig tartana, és a végén biztos nem járna jobban, mint ha elfogadta volna az eredetit. Ezt a stabil halmaz definíciójában nem követeltük meg, elképzelhető lenne, hogy az új elosztásban jobban jár az eredetileg eltérő vevő mint az eredetiben, és ezért megérhetné eltérnie. Erre a problémára az Alkuegyensúly fejezetben fogunk bővebben kitérni.

Nézzük meg, hogy néz ki egy ilyen stabil halmaz. Mindnek része az $\left(a_{1}, \mathbf{0}\right)$ elosztás. Utána, amíg lecsökken az eladó kifizetése $a_{2}$-re az így fennmaradó összeget teljes egészében az első vevő kapja. Ha tovább csökkentjük az első koordinátát láthatjuk, hogy a következő $a_{2}-a_{3}$-as részen az első két. . . az $a_{i}-a_{i+1}$-es részen az első $i$ és végül az utolsó $a_{n}-a_{n+1}=a_{n}$-es részen már az összes vevő osztozhat teljesen egyenrangú felekként.

Az előzőek miatt $\mathcal{U}$ a következőképpen néz ki: az $\left(a_{1}, \mathbf{0}\right)$ pontból kiindul egy $\left(-\left(a_{1}-\right.\right.$ $\left.\left.a_{2}\right), a_{1}-a_{2}, 0,0 \ldots 0\right)$ szakasz. Ennek a végpontjából egy háromszög melynek két oldala $\left(-\left(a_{2}-a_{3}\right), a_{2}-a_{3}, 0,0 \ldots 0\right)$ valamint $\left(-\left(a_{2}-a_{3}\right), 0, a_{2}-a_{3}, 0,0 \ldots 0\right)$, általában az $i$-edik lépésben amit addig kaptunk annak azokból a pontjaiból, amikben az eladó $a_{i}$-t kap kiindul egy-egy szimplex, aminek abból a csúcsból kiinduló $i$ darab éle a következő: mindnek az eladóhoz tartozó koordinátája $-\left(a_{i}-a_{i+1}\right)$, az elsőnek az első, a másodiknak a második. . a az utolsónak az $i$-edik vevőhöz tartozó koordinátája $a_{i}-a_{i+1}$, az összes többi koordináta 0 .

Innen látszik, hogy $\mathcal{U}$ csúcsai a következő elosztások: legyen $i_{j}$ az $1,2 \ldots n+1$ számokból alkotott szigorúan monoton növő $l$ elemű sorozat: az első vevő kifizetése $a_{1}-a_{i_{1}}$, az $i_{1}$-ediké $a_{i_{1}}-a_{i_{2}} \ldots$ az $i_{l-1}$-ediké $a_{i_{l-1}}-a_{i_{l}}$ az eladóé $a_{i_{l}}$ az összes többié 0 .

Nézzük meg geometriailag mindezt a 11. példán! 
23. ábra. $\mathcal{U}$ halmaz a 11. példában

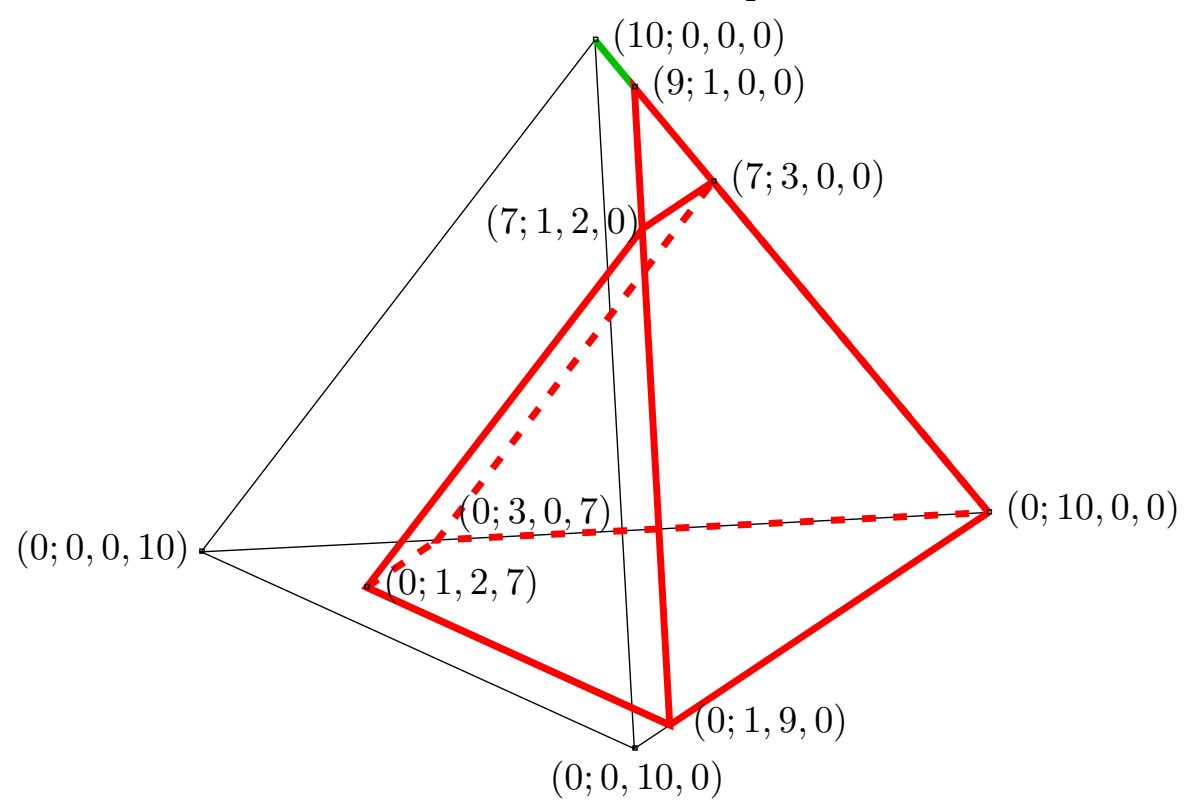

Ehhez képest az $\mathcal{X}$ halmaz tartalmaz még egy háromszöget, ahogy a 24 ábrán láthatjuk. Ebben a háromszögben az első vevő kifizetése 0, a második vevőé legalább 3 , mivel az eladó és a harmadik vevő együtt legfeljebb 7-et kap. A harmadik vevő kifizetése pedig legalább 1, mert az eladó és a második vevő együtt legfeljebb 9-et kap.

\subsection{Kapcsolat a határhozzájárulás vektorokkal}

$\mathcal{U}$ halmaz csúcsai speciális elosztásokhoz tartoznak, ennek megmutatásához definiáljuk a következő elosztásvektorokat:

Legyen $\theta: P \rightarrow\{1, \ldots, p\}$ a játékosok egy sorbarendezése, tehát az $i$ játékos pozíciója a $\theta$ szerinti sorrendben $\theta(i)$, míg $\theta^{-1}(k)$ adja meg, hogy melyik játékos áll a $k$-adik helyen a sorban. Jelölje $\Theta_{P}$ a $P$ halmaz összes lehetséges sorbarendezésének halmazát. Egy adott $\theta \in \Theta_{P}$ sorrendben az $i$ játékost megelöző játékosok halmazát jelölje $P_{i}^{\theta}=\{j \in P \mid \theta(j)<\theta(i)\}$, míg az első $k$ játékos halmazát $Q_{k}^{\theta}=\{j \in P \mid \theta(j) \leq k\}$.

Tegyük fel, hogy a játékosok egyenként társulnak a többiekhez, mégpedig egy adott $\theta \in \Theta_{P}$ sorrend szerint. Amennyiben egy csatlakozó játékos rögtön és teljes egészében megkapja az általa előidézett érték-növekményt, akkor az $i$ játékos kifizetése a $v$ játékban éppen $x_{i}^{\theta}(v)=v\left(P_{i}^{\theta} \cup\{i\}\right)-v\left(P_{i}^{\theta}\right)$ lesz. Tekintsük az így definiált komponensekből álló

$$
\boldsymbol{x}^{\theta}(v)=\left(x_{i}^{\theta}(v)=v\left(P_{i}^{\theta} \cup\{i\}\right)-v\left(P_{i}^{\theta}\right)\right)_{i \in P} \in \mathbb{R}^{P}
$$

kifizetés-vektort. 
24. ábra. $\mathcal{X}$ halmaz a 11. példában

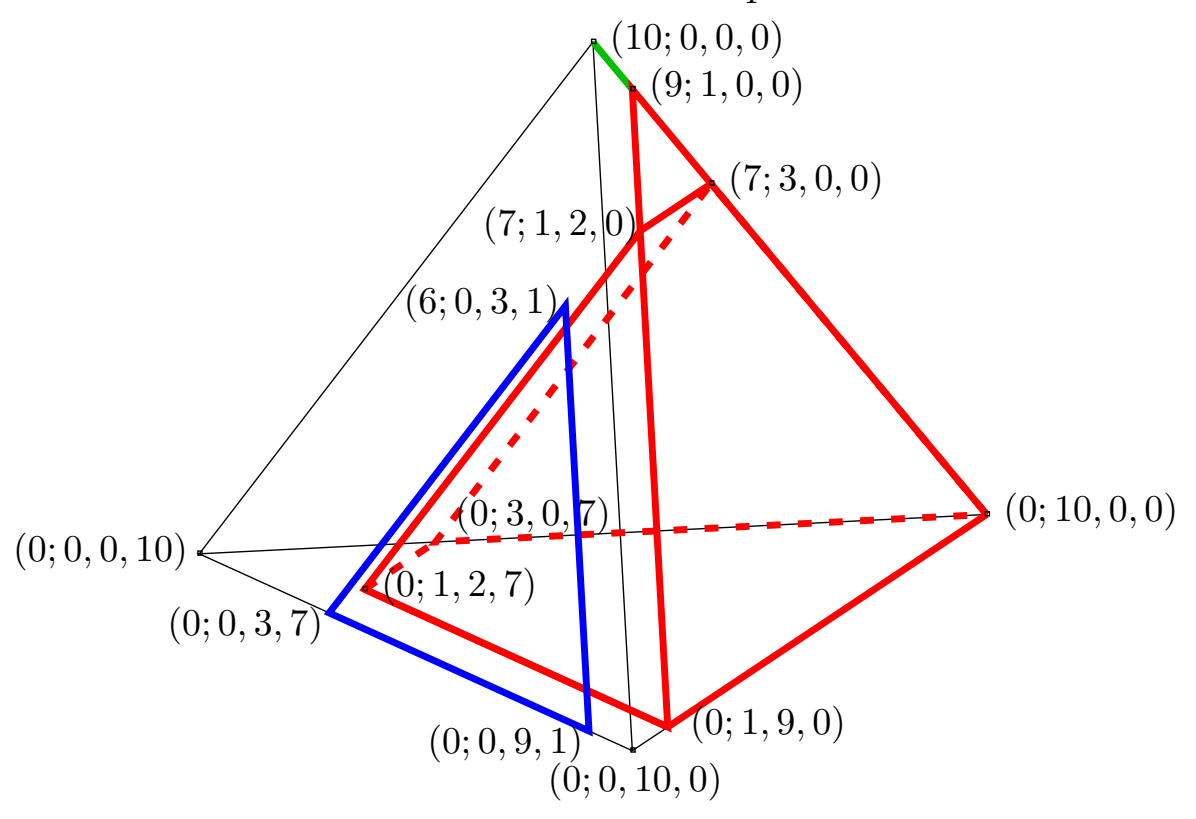

3.2.1. Definíció. Egy $(P, v)$ játékban a szereplők egy $\theta \in \Theta_{P}$ sorrendjéhez tartozó határhozzájárulás-vektor alatt az egyéni $x_{i}^{\theta}(v)$ határhozzájárulásokból álló vektort értjük.

Jelöljük a határhozzájárulás-vektorok halmazát $M$-mel. Az egy-eladós hozzárendelési játékok esetében az eladó határhozzájárulása biztos, hogy megegyezik valamelyik $a_{i}$ értékkel. Ha ö jön először akkor 0-t azaz $a_{n+1}$-et kap, különben azt az $a_{i}$-t amelyre $i$ az elötte érkező legkisebb sorszámú vevő. Legyen $M_{i}=\left\{(u, \boldsymbol{v}) \in M: u=a_{i}\right\}$. Ekkor az előzőek miatt $M=\bigcup_{i=1}^{n+1} M_{i}$.

3.2.2. Állítás. $\mathcal{U}$ csúcsai határhozzájárulás-vektorok:

\section{BIZONYÍTÁS.}

az $i_{1}, i_{2} \ldots i_{l}$ sorozathoz tartozó csúcs a következő sorrendhez tartozó határhozzájárulásvektor:

$$
\begin{gathered}
V_{i_{l}}, V_{i_{l+1}} \ldots V_{i_{n}}, E, V_{i_{l-1}}, V_{i_{l-1}+1} \ldots V_{i_{l}}-1, V_{i_{l-2}} \\
V_{i_{l-2}+1} \ldots, V_{i_{1}}, V_{i_{1}+1}, \ldots V_{i_{2}-1}, V_{1}, V_{2}, \ldots V_{i_{1}-1}
\end{gathered}
$$

ahol $E$ az eladót, $V_{j}$ pedig a $j$-edik vevőt jelöli. Szavakban ez a következő sorrendet jelenti: először bejön az l-edik vevő, majd sorban az utána jövők, utána az eladó, majd az $i_{l-1^{-}}$edik vevő, és sorban a nála gyengébbek, amikor elfogytak bejön az $i_{l-2^{-}}$ edik, utána a nála gyengébbek, és így tovább a végén bejön az $i_{1}$-edik utána a nála gyengébbek, legvégül az első vevő, utána meg akik még megmaradtak. $i_{l}=n+1$-re egyből az eladó jön be és utána ugyanúgy megy, mint az előző esetben. 


\subsection{3. Állítás.}

$$
\mathcal{U}=\bigcup_{i=1}^{n} \operatorname{conv}\left(M_{i} \cup M_{i+1}\right)
$$

BIZONYÍTÁS.

Legyen $\mathcal{U}_{i}=\left\{(u, \boldsymbol{v}) \in \mathcal{U}: a_{i} \geq u \geq a_{i+1}\right\}$. Triviális, hogy $\mathcal{U}=\bigcup_{i=1}^{n} \mathcal{U}_{i}$ Azt látjuk be, hogy $\mathcal{U}_{i}=\operatorname{conv}\left(M_{i} \cup M_{i+1}\right)$. $\mathcal{U}$ definíciójából látszik, hogy $\mathcal{U}_{i}$ egy konvex poliéder minden $i$-re Láttuk, hogy $\mathcal{U}_{i}$ csúcsai határhozzájárulás-vektorok, az kell még, hogy $M \subseteq \mathcal{U}$. Tegyük fel, hogy ez nem igaz, ekkor van egy olyan sorrend és $j$ index, amihez tartozó (uv) határhozzájárulás-vektorra

$$
\sum_{i=j}^{n} v_{i}>\left|a_{j}-u\right|_{+}
$$

1. $u>a_{j}$, akkor az eladó előtt kellett hogy jöjjön egy $j$-nél kisebb indexű vevő, ekkor viszont $v_{j}=v_{j+1}=\cdots=v_{n}=0$ tehát nem állhat fenn az egyenlőtlenség.

2. $u \leq a_{j}$ ekkor viszont, amikor az eladó és a j-ediknél nem nagyobb értékeléssel rendelkező vevők közül az utolsó érkezik, akinek pozitív a hozzájárulása az is legfeljebb $a_{j}$-re növeli a koalíció értékét, tehát $\sum_{i=j}^{n} v_{i}+u \leq a_{j}$, de ekkor megint nem állhat fenn az egyenlőtlenség.

3.2.4. Következmény. $\mathcal{U}$ halmaz konvex burka ugyanaz, mint a határhozzájárulásvektorok konvex burka, azaz a játék Weber halmaza (Weber, 1977).

3.2.5. Következmény. Az általában is igaz, hogy egy játék magja része a Weber halmaznak (Weber, 1977). Az 1-eladós hozzárendelési játékoknál többet is mondhatunk: minden stabil halmaz része a Weber halmaznak.

A stabil halmaz egy halmazértékű megoldás, a pontértékű megoldások közül az egyik legismertebb a Shapley-érték, ami a határhozzájárulás-vektorok átlaga. Az $\mathcal{U}$ halmaz előző jellemzése miatt felmerülhet a kérdés, hogy van-e mindig olyan stabil halmaz, ami tartalmazza a Shapley-értéket.

3.2.6. Megjegyzés. Van olyan játék, amire a Shapley-érték nincs benne egyetlen stabil halmazban sem: Legyen $A=\left[\begin{array}{ll}2 & 1\end{array}\right]$ ekkor a határhozzájárulás-vektorok: 
$(2,0,0)$ 3-szor

$(1,1,0)$

Tehát a Shapley-érték: $\left(\frac{7}{6}, \frac{4}{6}, \frac{1}{6}\right)$

Ez viszont nincs $U$-ban, mert $\left|a_{2}-\frac{7}{6}\right|_{+}=0<\frac{1}{6}$

Ez az eredmény nem is meglepő, mivel általában nincs benne a Shapley-érték $\mathcal{U}$-ban: ha $a_{n}>0$ akkor a Shapley-értékben az $n$-edik vevő kifizetése pozitív, mivel ha az eladó érkezik először és utána az n-edik vevő, akkor a határhozzájárulása $a_{n}$. A Shapley-érték csak úgy lehetne $\mathcal{U}$-beli, ha az eladó kifizetését $\phi_{E^{-}}$-vel jelölve:

$$
\phi_{E}=\sum_{i=1}^{n} \frac{a_{i}}{i \cdot(i+1)}<a_{n}
$$

de mivel

$$
\begin{gathered}
\sum_{i=1}^{n} \frac{a_{i}}{i \cdot(i+1)} \geq \sum_{i=1}^{j} \frac{a_{j}}{i \cdot(i+1)}+\sum_{i=j+1}^{n} \frac{a_{n}}{i \cdot(i+1)}= \\
=\sum_{i=1}^{j} \frac{a_{j}-a_{n}}{i \cdot(i+1)}+\sum_{i=1}^{n} \frac{a_{n}}{i \cdot(i+1)}=\frac{j}{j+1}\left(a_{j}-a_{n}\right)+\frac{n}{n+1} a_{n}
\end{gathered}
$$

így minden $j$-re fenn kell állnia a

$$
\begin{gathered}
\frac{j}{j+1}\left(a_{j}-a_{n}\right)+\frac{n}{n+1} a_{n}<a_{n} \\
\frac{j}{j+1}\left(a_{j}-a_{n}\right)<\frac{a_{n}}{n+1} \\
a_{j}<a_{n}+a_{n} \frac{j+1}{j(n+1)}
\end{gathered}
$$

egyenlőtlenségnek, ami azt jelenti, hogy az értékeléseknek nagyon közel kell lenniük egymáshoz speciálisan $j=1$-re

$$
a_{1}<a_{n} \frac{n+3}{n+1}
$$




\section{Alkuegyensúly}

A játékelmélet egy fontos kutatási területe az úgynevezett Nash-program, mely Nash (1953) cikke után kapta a nevét, amely a kooperatív és nemkooperatív megoldáskoncepciók között próbál kapcsolatot teremteni. Ebben a fejezetben hozzárendelési játékok, és az ezekből alkalmasan megkonstruált alkujátékok közti kapcsolatot fogjuk megvizsgálni.

A korábbi fejezetekben már említettük, hogy a stabil halmaz elnevezést az indokolja, hogy ha ennek a halmaznak egy eleme ellen egy koalíció fellép és kikényszerít egy másik, ezt domináló elosztást, akkor van egy másik koalíció, amelyik kikényszerítheti, hogy visszatérjenek egy, a stabil halmazbeli elosztásba (nem feltétlen az eredetibe). Ezért a halmaztól való minden eltérés csak ideiglenes lehet, így nem is éri meg ettől eltérni.

Harsanyi (1974) a stabil halmazoknak ezt az interpretációját kritizálta, mert csak annyi igaz, hogy a halmaz valamely pontjába kerülnek vissza, de lehet, hogy ez az utóbbi pontja a halmaznak az eredeti elosztástól eltérő koalíció minden tagja számára szigorúan jobb, csak számukra nem volt megvalósítható, így közvetlenül nem tudtak volna eljutni oda, csak a másik koalíció segítségével. Ha ez a helyzet, akkor mégis van olyan koalíció, amelyik fel fog lépni a stabil halmazbeli elosztás ellen, tehát a halmaz „nem is olyan stabil".

Ez a probléma abból adódik, hogy a dominancia relációban rövidlátóak a játékosok: csak az érdekli őket, hogy a következő lépésben szigorúan jobban járjanak. Ezzel szemben az előbb leírt példában a koalíciók már számoltak azzal, hogy ha eltérnek, akkor egy következő koalíció is el fog térni..., és több lépéssel később mi lesz a helyzet. Az ilyen, több lépésben történő dominanciát nevezte Harsányi közvetett dominanciának, mert itt a két kifizetésvektor nem közvetlenül, hanem csak egy más vektorokon át vezető úton közvetetten dominálja egymást.

4.0.1. Definíció (Közvetett dominancia). Egy $\boldsymbol{y}$ vektor közvetetten dominálja az $\boldsymbol{x}$ vektort a koalíciók egy $S_{1}, S_{2} \ldots S_{n}$ sorozatán keresztül, ha létezik egy olyan $\boldsymbol{x}=$ $\boldsymbol{x}^{0}, \boldsymbol{x}^{1}, \boldsymbol{x}^{2}, \ldots, \boldsymbol{x}^{n-1}, \boldsymbol{x}^{n}=\boldsymbol{y}$ sorozat, amiben minden $i=1,2, \ldots, n$-re $\boldsymbol{x}^{i} \operatorname{dom}_{S_{i}} \boldsymbol{x}^{i-1}$ továbbá minden $j \in S_{i}:-r e \boldsymbol{y}_{j}>\boldsymbol{x}_{j}^{i-1}$.

Itt az $S_{1}$ koalíció nem csak a következő állapottal számol, hanem azzal is, hogy ha ők kikényszerítik az $\boldsymbol{x}^{1}$ vektort, akkor utána az $S_{2}$ kikényszeríti az $\boldsymbol{x}^{2}$-t. . végül eljutnak az $\boldsymbol{y}$ vektorhoz. Az $S_{i}$ koalíció tagjainak akkor éri meg folytatni ezt a láncot, ha az $\boldsymbol{y}$ vektor előnyösebb számukra mint az $\boldsymbol{x}^{i-1}$, amitől ők térnek el.

1. Példa. Nézzük az $A=[10,6,2]$ mátrixhoz tartozó hozzárendelési játékot. Ebben a játékban a $(0 ; 10,0,0)$ elosztást közvetetten dominálja a $(2 ; 7,0,1)$ a koalíciók $\left\{M, N_{3}\right\}$, 
$\left\{M, N_{1}\right\}$ és az elosztások $(0 ; 10,0,0),(1 ; 6,2,1),(2 ; 7,0,1)$ sorozatán keresztül, mivel $(2 ; 7,0,1) \operatorname{dom}_{1}(1 ; 6,2,1) \operatorname{dom}_{3}(0 ; 10,0,0)$ és az $\left\{M, N_{3}\right\}$ koalíció mindkét tagja számára elönyösebb a $(2 ; 7,0,1)$ elosztás, mint a $(0 ; 10,0,0)$. Közvetlen dominancia viszont nincs a két vektor között. Ilyen dominancia csak az eladó és a harmadik vevő alkotta koalíción keresztül lenne lehetséges, mivel a $(2 ; 7,0,1)$ vektor csak számukra elönyösebb a másiknál, számukra viszont ez nem elérhetö.

Ezen a számpéldán láthatjuk is Harsányi kritikájának értelmét, és hogy a probléma a legegyszerűbb hozzárendelési játékoknál is fennállhat. A stabil halmaz definíciójába belefér, hogy eleme legyen a $(0 ; 10,0,0)$ és a $(2 ; 7,0,1)$ pont is mivel ezek nem dominálják egymást. Ha az aktuális állapot az előbbi vektor, akkor az eladó és a harmadik vevő nem képes kikényszeríteni az utóbbit, az $(1 ; 6,2,1)$ vektort viszont igen, az az indoklás, hogy ezt nem fogják megtenni, mert a halmaztól való eltérés csak ideiglenes, és valakik ki tudják kényszeríteni majd a $(2 ; 7,0,1)$ vektort nem tűnik meggyőzőnek, ezzel az indokkal az eladót és a harmadik vevőt nem lehetne meggyőzni. Természetesen pusztán a definíció alapján az eladó és a harmadik vevő nem tudhatja biztosan, hogy ebbe a $(2 ; 7,0,1)$ pontba jutunk vissza, lehet hogy van más is ami dominálja a köztes pontot, de elképzelhető olyan eset is, hogy tudják. Harsanyi (1974) definiálta a játékoknak azon osztályát, ahol ilyen probléma nem állhat fenn.

4.0.2. Definíció (Abszolút stabil játék). Azokat a játékokat, ahol a közvetett dominanciából következik a közvetlen, azaz ha egy elosztás dominál egy másikat egy S koalícióval kezdődő sorozaton keresztül, akkor az S koalición keresztül közvetlenül is dominálja, abszolút stabil játékoknak nevezzük.

Könnyü belátni, hogy minden olyan játék abszolút stabil, amiben csak a $|P|-1$ tagú és a nagykoalíció értéke pozitív, a többié 0 . Ilyen például minden legfeljebb 3 fős játék.

Abban az esetben ha a szokásos dominanciarelációt lecseréljük a közvetett dominanciára Diamantoudi \& Xue (2006) megmutatták, hogy Lucas (1968a) híres 10 személyes ellenpéldájában már van stabil halmaz.

A közvetett dominanciát természetesen sokféleképpen lehetne definiálni. Harsanyi (1974) is megemlíti, hogy amikor az egyik koalíció kikényszerít egy új vektort, az nem feltétlen kell megkövetelni, hogy az új dominálja a régit, azaz a koalíció minden tagja jobban járjon, elég lehet annyit elvárni, hogy az új elérhető legyen a koalíció számára. Ha előrelátó játékosokat feltételezünk, akkor úgyis a végső állapot érdekli őket nem a közvetlen következő. Az, hogy melyik definíciónak milyen előnyei és hátrányai vannak nagyon messze vezetne, a témánktól. A fejezet célja csak, hogy bemutassuk a problémát és a 2.1.2. tételben szereplő karakterizáció egy alkalmazását. Annak, hogy miért 
pont ezt a fajta közvetett dominanciát, majd később alkujátékot és egyensúlyfogalmat választottuk két oka is van. Az egyik, hogy már Harsanyi (1974) is ezeket vizsgálta a probléma felvetésekor, a másik (és őszintébb) indok, hogy nagy szükségünk van az eredeti dominancia relációra, és ezek a fajta definíciók mentik át a számunkra jó tulajdonságait. Ezekre van bármilyen eredményünk a kooperatív és nemkooperatív játék megoldásai közti kapcsolatra. A közvetett dominanciával és a stabil halmazokkal a TU játékoknál is általánosabb környezetben Suk-Young (1994) cikkét érdemes megemlíteni.

\subsection{Az alkujáték}

az 1. példában is láttuk, hogy problémát jelenthet, hogy a játékosok nem tudják melyik dominancia fog megvalósulni, ha egy koalíció eltér egy elosztástól, és kiharcol egy másikat, akkor attól sokszor sok koalíció is képes lesz eltérni, nem tudjuk, hogy végül melyik fog, így kérdés, hogy az eredetileg eltérőnek megéri-e. Ennek a modellezésére Harsanyi (1974) javasolt egy nemkooperatív játékot, melyet kis változtatással az alábbiakban bemutatunk (a változtatások nem lényegesek, inkább technikai jellegűek, a később kimondott tétel bizonyítása lesz tőle kicsit egyszerübb):

A játékosok halmaza itt is legyen $P$, és a játék a következő forgatókönyv szerint zajlik: van egy $\boldsymbol{x}^{0}$ vagy félelosztás vektor, ami azt mutatja, hogy éppen hol áll az alku. Az alku során ettől úgy térhetünk el, ha egy koalíció tagjai szimultán módon ugyanazt az aktuális vektort domináló félelosztás vektort mondják. Ebben az esetben ez lesz az alkuban az aktuális helyzet és megint lehetősége van egy koalíciónak dominálni.

A kérdés az, hogy hogyan döntsük el, melyik koalíciónak adjuk meg a lehetőséget egy új ajánlat tételére. Ezen a ponton térünk el Harsányitól. Ö ehhez bevezetett egy új játékost, az alkuvezetőt, aki mindig kijelöl egy koalíciót. Az alkuvezető célja, hogy a játékosok minél tovább alkudozzanak. Ezt úgy lehet legegyszerübben megoldani, hogy azt mondjuk, hogy ha az alku $n$ elfogadott ajánlat után ér véget, akkor a vezető kifizetése például $2-\left(\frac{1}{2}\right)^{n}$ (ha soha nem ér véget akkor legyen 2). Az alkunak pedig akkor van vége, ha egy kijelölt koalíció nem tesz sikeresen új ajánlatot. A többi koalíciónak azért nem kell megadni a lehetöséget ebben az esetben, mivel egyensúlyi stratégiaprofil esetén azok egyike sem folytatná tovább az alkut, mivel ha mégis így lenne akkor az alku vezetőjének azt a koalíciót kellett volna kijelölnie.

Mi ezzel szemben a következőképpen fogunk eljárni: az új játékos bevezetése helyett minden félelosztásvektorhoz megadjuk a koalícióknak egy sorrendjét (ez lehet akár mindig ugyanaz a sorrend is, és ez a játékosok számára köztudott tudás), és ilyen sorrendben adjuk meg a lehetőséget az új ajánlat tételére. Az alku pedig akkor fog végetérni, ha 
egyik koalíció sem tesz sikeres új ajánlatot. A játék definíciójából úgy tünhet, hogy a kapott egyensúlyok nagyban függeni fognak a sorrendektől, de mint később látni fogjuk ez nem így van.

A kifizetések pedig: ha véget ér az alku (tehát van olyan félelosztás, amiből egy koalíció sem akar továbbmenni) akkor a játékosok ezt a félelosztást kapják, ha az alku nem ér véget, akkor minden játékos megkapja a saját maga alkotta egyszemélyes koalíció értékét (mivel az összes ajánlat félelosztás, így bármely lehetséges ajánlat elfogadása esetén sem járna senki ennél rosszabbul).

A játék definiálása után a kérdés az, hogy milyen egyensúlyt vizsgáljunk. Harsányihoz hasonlóan mi is a részjáték tökéletes erős Nash-egyensúlyi stratégiaprofilokat fogunk keresni. Az erős Nash-egyensúlyra (ahol nem csak a játékosok egyénenként, hanem semelyik koalíció sem képes profitálni abból ha megváltoztatja a stratégiáját) azért van szükség, mert ha csak a sima Nash-egyensúlyt vennénk, akkor Egyensúly lenne például az a profil is, ahol soha senki nem akar dominálni (ettől ha csak egy ember akar eltérni az nem változtat semmit, így ez egy Nash-egyensúlyi profil lenne), az ilyeneket viszont nem szeretnénk megengedni.

Feltesszük, hogy ha egy koalíció egy adott állapotban nem akar dominálni, akkor amikor rájuk kerül a sor, akkor az éppen aktuális állapotot fogják javasolni (és nem különböző javaslatokat fognak tenni vagy egy olyan vektort, amelyik nem képes dominálni). Így azokat az állapotokat, amelyekben megáll az alku, nevezhetjük a stratégiaprofil fixpontjának. Feltesszük továbbá, hogy egy koalíció csak akkor dominál, ha ezzel minden tagja szigorúan jobban jár. Ha valakinek mindegy hogy dominál-e, mert végül úgyis ugyanazt a kifizetést kapja, akkor inkább nem dominál.

Az így definiált játékokban, a stabil halmazokkal ellentétben már van szerepe a közvetett stabilitásnak is. Speciális esetben az így definiált játékok fixpontjai (ami az alkujáték végeredménye lehet), megegyeznek a kooperatív játék stabil halmazaival, azaz a fixpontok stabil halmazt alkotnak, és minden stabil halmazhoz található egyensúlyi stratégiaprofil, aminek a stabil halmaz elemei a fixpontjai. Harsanyi (1974) megmutatta, hogy mivel az abszolút stabil játékok osztályán nem különbözik a közvetlen és a közvetett dominancia, a stabil halmazok elöállnak, mint egyensúlyi stratégiák fixpontjai.

4.1.1. Tétel. Az abszolút stabil játékokban a Harsányi-féle alkujáték részjáték tökéletes koalíciós Nash-egyensúlyi stratégiaprofiljainak fixpontjai egy stabil halmazt alkotnak. Fordítva, minden stabil halmazhoz található egy részjáték tökéletes koalíciós Nashegyensúlyi stratégiaprofil, amelynek fixpontjai a halmazbeli kifizetések.

A fejezet hátralévő részében ezt az állítást fogjuk belátni a hozzárendelési játékok- 
ra. (amelyek, mint az a 1. példából is látható, csak nagyon elfajult esetben abszolút stabilak). Ebben nagy segítségünkre lesz a 2.1.2. tételben bemutatott karakterizációja a stabil halmazoknak.

\subsection{Kapcsolat a stabil halmazokkal}

4.2.1. Állítás. Az egyensúlyi stratégiák fixpontjainak halmaza zárt.

BizONYÍTÁs.

Tegyük fel, hogy az állítás nem igaz, azaz van egy $\boldsymbol{x}^{i}$ fixpontokból álló sorozat, aminek $\boldsymbol{x}$ határértéke nem fixpont. Ekkor létezik $\epsilon>0$ és egy koalíció, amelynek megéri eltérni az $\boldsymbol{x}$ vektortól, mert az alku végén a koalíció minden tagja szigorúan jobban fog járni legalább $\epsilon$-nal. Ebben az esetben viszont $\boldsymbol{x}$ vektor $\frac{\epsilon}{2}$ sugarú környezetében nem lehet fixpont, mert az előző koalíciónak ettől a fixponttól is megérné ugyanígy eltérni, ami ellentmondás.

4.2.2. Állítás. Az egyensúlyi stratégiák fixpontjainak halmazára teljesül a belső stabilitás.

BizONYÍTÁs.

Tegyük fel, hogy az állítás nem igaz és van $\boldsymbol{x}, \boldsymbol{y}$ fixpont valamint egy $S$ koalíció, amin keresztül $\boldsymbol{y}$ dominálja $\boldsymbol{x}$-et. Ebben az esetben az $S$ koalíciónak megéri változtatnia a stratégiáján: ha az $\boldsymbol{x}$ helyzetben, amikor rájuk kerül a sor, akkor mindenki $\boldsymbol{y}$-t mond az $\boldsymbol{x}$ helyett, azzal mindannyian nyernek, mivel $\boldsymbol{y}$ elosztás fixpont volta miatt az alku ott fog megállni, és ezzel mind jobban járnak, mivel $\boldsymbol{y}$ dominálja $\boldsymbol{x}$-et. Ezért az eredeti stratégia nem lehetett egyensúlyi.

4.2.3. Állítás. Egy egyensúlyi stratégiához tartozó fixpontok halmaza része az elosztáshalmaznak.

BizONYÍTÁs.

Tegyük fel, hogy az állítás nem igaz, és van egy $\boldsymbol{x} \in \mathcal{I}^{\prime} \backslash \mathcal{I}$ fixpont. Növeljük meg $\boldsymbol{x}$ minden koordinátáját $\frac{v(P)-\boldsymbol{x}(P)}{|P|}$-vel, és jelöljük ezt a vektort $\boldsymbol{y}$-nal. Nyilvánvaló, hogy $\boldsymbol{y} \in \mathcal{I}$ és $\boldsymbol{y} \operatorname{dom}_{P} \boldsymbol{x}$. Ha $\boldsymbol{x}$ fixpont volt, akkor $\boldsymbol{y}$-nak is annak kell lennie, mivel, ha $\boldsymbol{y}$-tól megéri eltérni egy koalíciónak, akkor $\boldsymbol{x}$-től is. Viszont $\boldsymbol{y}$ dominálja $\boldsymbol{x}$-et a nagykoalíción keresztül, ami a 4.2.2. állítás miatt ellentmondás.

Ezek az eredmények általánosan is igazak minden kooperatív játékból származtatott alkujátékban. Hozzárendelési játékok esetén ennél több is elmondható: 
4.2.4. Állítás. Hozzárendelési játékban az egyensúlyi stratégiák fixpontjainak halmaza háló.

BizONYÍTÁs.

A bizonyítás nagyon hasonló az 1.3.4 állításban a mag valamint a stabil halmaz háló tulajdonságának bizonyításához.

Legyen $\left(\boldsymbol{x}^{1} ; \boldsymbol{y}^{1}\right)$ és $\left(\boldsymbol{x}^{2} ; \boldsymbol{y}^{2}\right)$ két fixpont. Ekkor $\left(\boldsymbol{x}^{1} \vee \boldsymbol{x}^{2} ; \boldsymbol{y}^{1} \wedge \boldsymbol{y}^{2}\right)$ és $\left(\boldsymbol{x}^{1} \wedge \boldsymbol{x}^{2} ; \boldsymbol{y}^{1} \vee \boldsymbol{y}^{2}\right)$ közül legalább az egyik félelosztás. A szimmetria miatt választhatjuk az elsőt. Ha ez nem lenne fixpont, akkor van olyan $(i, j)$ koalíció, amelynek megérné ettől eltérni és egy $\left(\boldsymbol{x}^{3} ; \boldsymbol{y}^{3}\right)$ félelosztást mondani. Szimmetria miatt feltehetö, hogy $y_{j}^{1} \leq y_{j}^{2}$. Ekkor viszont $\left(\boldsymbol{x}^{3} ; \boldsymbol{y}^{3}\right) \operatorname{dom}_{i j}\left(\boldsymbol{x}^{1} ; \boldsymbol{y}^{1}\right)$ miatt az $(i ; j)$ vegyespárosnak megéri eltérnie az $\left(\boldsymbol{x}^{1} ; \boldsymbol{y}^{1}\right)$ esetben is, tehát az nem lehet fixpont.

Azt kaptuk tehát, hogy ha $\left(\boldsymbol{x}^{1} \vee \boldsymbol{x}^{2} ; \boldsymbol{y}^{1} \wedge \boldsymbol{y}^{2}\right)$ egy félelosztás, akkor fixpont is. A 4.2.3. állítás miatt ekkor $\left(\boldsymbol{x}^{1} \vee \boldsymbol{x}^{2} ; \boldsymbol{y}^{1} \wedge \boldsymbol{y}^{2}\right)$ egy elosztás, ekkor viszont $\left(\boldsymbol{x}^{1} \wedge \boldsymbol{x}^{2} ; \boldsymbol{y}^{1} \vee \boldsymbol{y}^{2}\right)$ is elosztás tehát fixpont is, azaz a fixpontok halmaza háló.

4.2.5. Állítás. Hozzárendelési játékban az egyensúlyi stratégiák fixpontjainak halmaza tartalmaz egy olyan pontot, amiben mindent az eladók kapnak, és egy olyan pontot, amiben mindent a vevők kapnak.

BizONYÍTÁs.

A szimmetria miatt elég megmutatni, hogy van olyan pont, amiben mindent az eladók kapnak. Az 4.2.1. és a 4.2.4. állítás miatt tudjuk, hogy a fixpontok halmaza egy zárt háló, így van olyan pontja, amelyben az eladók azt maximális összeget kapják, amit csak egy fixpontban kaphatnak. Ha ebben nem mindent az eladók kapnak, akkor vegyük azt a pontot, amiben a vevők kifizetését az eladók között egyenlő arányban osztjuk szét. Ez nem lehet fixpont, mivel minden eladó többet kap, mint a maximális fixpontban. Ekkor viszont van olyan koalíció, amelyiknek megéri ettől eltérni, mert az alku végén egy ennél szigorúan jobb elosztáshoz jut. Ilyen viszont nem lehet, mert ennek az utolsó pontnak egy fixpontnak kell lennie, ezekben viszont az eladók nem járhatnak jobban mint az eredeti eladóoptimális elosztásban.

4.2.6. Állítás. Hozzárendelési játékban az egyensúlyi stratégiák fixpontjainak a halmaza összefüggö.

BIZONYÍTÁs.

4.2.1. állításból tudjuk,hogy a fixpontok halmaza zárt, így 2.1.2. lemma miatt elég megmutatnunk, hogy bármely két fixpont között létezik egy harmadik. 
Legyen $\left(\boldsymbol{x}^{1} ; \boldsymbol{y}^{1}\right)$ és $\left(\boldsymbol{x}^{2} ; \boldsymbol{y}^{2}\right)$ két fixpont. Feltehetö, hogy $\boldsymbol{x}^{1} \leq \boldsymbol{x}^{2}$ és $\boldsymbol{y}^{1} \geq \boldsymbol{y}^{2}$ (vagy mindkét reláció pont fordítva áll, de az szimmetria miatt nem probléma), mivel ha nem így lenne, akkor a két elem valamelyik hálókombinációját véve kapunk egy megfelelö harmadik pontot. Legyen $\left(\boldsymbol{x}^{3} ; \boldsymbol{y}^{3}\right)=\frac{\left(\boldsymbol{x}^{1} ; \boldsymbol{y}^{1}\right)+\left(\boldsymbol{x}^{2} ; \boldsymbol{y}^{2}\right)}{2}$. Ha $\left(\boldsymbol{x}^{3} ; \boldsymbol{y}^{3}\right)$ fixpont akkor találtunk egy $\left(\boldsymbol{x}^{1} ; \boldsymbol{y}^{1}\right)$ és $\left(\boldsymbol{x}^{2} ; \boldsymbol{y}^{2}\right)$ közti fixpontot. Ha nem fixpont, akkor van olyan $(i ; j)$ vegyespáros, akiknek megéri eltérni az $\left(\boldsymbol{x}^{3} ; \boldsymbol{y}^{3}\right)$ elosztástól, mert így az alku végén egy $\left(\boldsymbol{x}^{4} ; \boldsymbol{y}^{4}\right)$ fixponthoz jutnak, ami mindkettejüknek elönyösebb, mint $\left(\boldsymbol{x}^{3} ; \boldsymbol{y}^{3}\right)$. Ha $x_{i}^{1} \leq x_{i}^{3}$ és $y_{j}^{1} \leq y_{j}^{3}$, akkor az $\left(\boldsymbol{x}^{1} ; \boldsymbol{y}^{1}\right)$ elosztástól is megérné eltérni. Tehát $x_{i}^{1}>x_{i}^{3}$-nek vagy $y_{j}^{1}>y_{j}^{3}$-nek fenn kell állnia. A szimmetria miatt feltehetö, hogy az első eset áll fenn. Ekkor $x_{i}^{1}>x_{i}^{3}=\frac{x_{i}^{1}+x_{i}^{2}}{2}>x_{i}^{2}$. Hasonlóan $x_{i}^{2}>x_{i}^{3}$ és $y_{j}^{2}>y_{j}^{3}$ közül is valamelyiknek teljesülnie kell. Az első egyenlőtlenség nem teljesülhet, így a másodiknak kell teljesülnie. Ekkor $y_{j}^{2}>y_{j}^{3}=\frac{y_{j}^{1}+y_{j}^{2}}{2}>y_{j}^{1}$. 4.2 .4 miatt $\operatorname{med}\left(\left(\boldsymbol{x}^{1} ; \boldsymbol{y}^{1}\right) ;\left(\boldsymbol{x}^{2} ; \boldsymbol{y}^{2}\right) ;\left(\boldsymbol{x}^{4} ; \boldsymbol{y}^{4}\right)\right)$ fixpont, és $y_{j}^{1}<y_{j}^{3}<y_{j}^{4}$, valamint $x_{i}^{2}<x_{i}^{3}<x_{i}^{4}$ miatt különbözik $\left(\boldsymbol{x}^{1} ; \boldsymbol{y}^{1}\right)$-től és $\left(\boldsymbol{x}^{2} ; \boldsymbol{y}^{2}\right)$-töl.

Mivel a fixpontok halmaza zárt és bármely két pontja közt van egy harmadik, így összefüggo" is.

4.2.7. Állítás. Hozzárendelési játékban az egyensúlyi stratégiák fixpontjainak halmaza tartalmazza a bármely két pontja közti félelosztások magját.

\section{BIZONYÍTÁS.}

Vegyünk két $\left(\boldsymbol{x}^{1} ; \boldsymbol{y}^{1}\right)$ és $\left(\boldsymbol{x}^{2} ; \boldsymbol{y}^{2}\right)$ fixpontot. Felteheto, hogy $\boldsymbol{x}^{1} \geq \boldsymbol{x}^{2}$ és $\boldsymbol{y}^{1} \leq \boldsymbol{y}^{2}$, mivel ha a két pont helyett a két pont két hálókombinációját vesszük azok is fixpontok 4.2.4. állítás miatt, ugyanazt a téglatestet határozzák meg, és azokra már teljesül a két egyenlőtlenség. Az $\left(\boldsymbol{x}^{1} ; \boldsymbol{y}^{1}\right)$ és $\left(\boldsymbol{x}^{2} ; \boldsymbol{y}^{2}\right)$ pontok közti félelosztások magja, azon $(\boldsymbol{x} ; \boldsymbol{y})$ félelosztásokból áll, amelyek ezen két pont között vannak, és minden $(i ; j)$ vegyespárosra $x_{i}+y_{j} \geq a_{i j}$ vagy $x_{i}=x_{i}^{1} \vee x_{i}^{2}=x_{i}^{1}$ vagy $y_{j}=y_{j}^{1} \vee y_{j}^{2}=y_{j}^{2}$. Ha egy ilyen félelosztás nem fixpont, akkor van olyan vegyespáros, amelyiknek megéri ettől eltérni, de akkor ennek a vegyespárosnak ugyanígy megéri $\left(\boldsymbol{x}^{1} ; \boldsymbol{y}^{1}\right)$-től vagy $\left(\boldsymbol{x}^{2} ; \boldsymbol{y}^{2}\right)$-től is eltérni, mivel erre a vegyespárosra a három egyenlőtlenség közül az első nem teljesülhetett, mert attól nem tudtak volna eltérni, ha a második teljesül, akkor ugyanígy az $\left(\boldsymbol{x}^{1} ; \boldsymbol{y}^{1}\right)$-töl is megérné eltérniük, mvel $x_{i}^{1}=x_{i}$ és $y_{i}^{1} \leq y_{j}\left(\operatorname{mivel}(\boldsymbol{x} ; \boldsymbol{y})\right.$ az $\left(\boldsymbol{x}^{1} ; \boldsymbol{y}^{1}\right)$ és $\left(\boldsymbol{x}^{2} ; \boldsymbol{y}^{2}\right)$ fixpontok között van). Szimmetria miatt ugyanilyen a helyzet akkor is ha a harmadik egyenlötlenség teljesül.

4.2.1. Tétel. Hozzárendelési játékban az egyensúlyi stratégiák fixpontjai stabil halmazt alkotnak. 


\section{BizONYÍTÁs.}

A bizonyításhoz felhasználjuk a stabil halmazok hozzárendelési játékokon vett karakterizációját, amit a 2.1.2. tételben láttunk be. Eszerint meg kell mutatni, hogy a fixpontok halmaza

1. teljesíti a belső stabilitást,

2. tartalmaz egy olyan pontot, ahol mindent az eladók kapnak és egy olyat, ahol mindent a vevők kapnak,

3. összefüggö,

4. tartalmazza a bármely két pontja közti elosztások magját.

Azt, hogy minden fixpont elosztás a 4.2.3. állításban, a belső stabilitást 4.2.2. állításban, azt, hogy tartalmazza a két szélsőséges elosztást 4.2.5. állitásban láttuk be, az összefüggőséget a 4.2.6. állításban, az utolsó feltételt pedig 4.2.7. állításban mutattuk meg.

Ennek az állításnak a forditottja is igaz.

4.2.2. Tétel. Hozzárendelési játékban minden stabil halmazhoz található egyensúlyi stratégiaprofil, aminek a fixpontjai a stabil halmaz elemei.

\section{BIZONYÍTÁS.}

Legyen $\mathcal{V}$ egy stabil halmaz az $A$ mátrixhoz tartozó hozzárendelési játékban és legyen $\mathcal{X} \subseteq \mathcal{V}$ egy, a $\mathcal{V}$ vevő- és eladóoptimális pontjait összekötö monoton görbe 2.1.2. tétel miatt ez tényleg létezik). Vegyük azt a stratégiaprofilt, amelyben az $(i ; j)$ koalíció a következőt teszi ha $(\boldsymbol{x} ; \boldsymbol{y})$ pontban áll a játék:

- ha $(\boldsymbol{x} ; \boldsymbol{y}) \in \mathcal{V}$, akkor nem akarnak dominálni, azaz mindketten $(\boldsymbol{x} ; \boldsymbol{y})$-t mondanak,

- ha $(\boldsymbol{x} ; \boldsymbol{y}) \in \mathcal{V}$ és nincs az $\mathcal{X}$ görbének olyan pontja, amivel mindketten jobban járnak, akkor szintén nem akarnak dominálni,

- ha $(\boldsymbol{x} ; \boldsymbol{y}) \in \mathcal{V}, \mathcal{X}$-nek van olyan pontja, amivel mindketten jobban járnak, és az dominálja is $(\boldsymbol{x} ; \boldsymbol{y})$-t, akkor mindketten ezt mondják (ha több ilyen van akkor ezek közül egyet),

- ha $(\boldsymbol{x} ; \boldsymbol{y}) \in \mathcal{V}, \mathcal{X}$-nek van olyan pontja, amivel mindketten jobban járnak, de ezek egyike sem dominálja $(\boldsymbol{x} ; \boldsymbol{y})$-t, (mert nem elérhető az $(i ; j)$ vegyespáros számára,) akkor legyen $\left(\boldsymbol{x}^{1} ; \boldsymbol{y}^{1}\right)$ az a pont az $(\boldsymbol{x} ; \boldsymbol{y})$-t és $(\boldsymbol{u} ; \boldsymbol{v})$-t összekötő szakaszon, amelyre 
$x_{i}^{1}+y_{j}^{1}=a_{i j}$. Legyen $\left(\boldsymbol{u}^{1} ; \boldsymbol{v}^{1}\right)$ az $\mathcal{X}$ görbének egy olyan pontja, amelyre $x_{i}^{1}=u_{i}^{1}$, $\left(\boldsymbol{u}^{2} ; \boldsymbol{v}^{2}\right)$ pedig egy olyan, amire $y_{j}^{2}=v_{j}^{2}$. Ilyen van, mivel az $(\boldsymbol{u} ; \boldsymbol{v}) \in \mathcal{X}$ pontnak a megfelelő koordinátái nagyobbak, mint $\left(\boldsymbol{x}^{1} ; \boldsymbol{y}^{1}\right)$-nek, $\mathcal{X}$ végpontjaiban a megfelelő koordináták kisebbek, és $\mathcal{X}$ összefüggősége miatt minden, a kettő közötti értéket felveszi $\mathcal{X}$-nek valamelyik pontja. Legyen $\left(\boldsymbol{x}^{3} ; \boldsymbol{y}^{3}\right)$ az $\left(\boldsymbol{x}^{1} ; \boldsymbol{y}^{1}\right)$ és $\left(\boldsymbol{x}^{2} ; \boldsymbol{y}^{2}\right)$ vektorok minimuma, azaz $\left(\boldsymbol{x}^{3} ; \boldsymbol{y}^{3}\right)=\left(\boldsymbol{x}^{1} \wedge \boldsymbol{x}^{2} ; \boldsymbol{y}^{1} \wedge \boldsymbol{y}^{2}\right)$.

Ebben az esetben az $(i ; j)$ koalíció mindkét tagja ezt az $\left(\boldsymbol{x}^{3} ; \boldsymbol{y}^{3}\right)$ vektort mondja be.

Ez egyensúlyi stratégia lesz, mivel ha mindenki ezt játssza, akkor biztos, hogy egy $\mathcal{V}$-beli pontba (általában $\mathcal{X}$-belibe, kivéve ha eredetileg $\mathcal{V}$-ből indult az alku) jutunk. A fent leírt stratégiától egyik koalíciónak sem éri meg eltérnie mivel:

- Egy $\mathcal{V}$-beli pontból egy koalíciónak sem éri meg eltérnie, mivel ha eltérnek, akkor az alku végén biztos, hogy egy másik $\mathcal{V}$ beli vektorba jutnak el, ami $\mathcal{V}$ belső stabilitása miatt nem lehet mindkettejüknek előnyösebb, mint az eredeti.

- Ha nem $\mathcal{V}$ beli pontból indulunk ki, akkor az eredeti stratégia végül egy $\mathcal{X}$-beli pontot fog eredményezni. Ezen egy koalíciónak sem éri meg változtatni. Tegyük fel, hogy mégis megéri ez a játékosok egy csoportjának. Nézzük az utolsó párost akik eltértek. Ök egy $\mathcal{V} \backslash \mathcal{X}$ beli pontot mondtak (ha nem ilyet akkor onnan végül egy $\mathcal{X}$ belibe érne az alku, mivel onnantól mindenki követi az eredeti stratégiát). Ez az elosztás viszont dominálja azt a $\mathcal{X}$-belit ahova eltérés nélkül jutottak volna, mivel megvalósítható az utolsó pár számára és előnyösebb is (különben nem érte volna meg változtatni a stratégián), ami ellentmond $\mathcal{X}$ belső stabilitásának.

- Eddig azt láttuk, hogy ha a fent leírt stratégiától egy koalíció eltér, az is egy $\mathcal{X}$ beli kifizetést fog eredményezni. $\mathcal{X}$ monotonitása miatt viszont nem érheti meg szigorúan a páros mindkét tagjának eltérni, hogy a mostani végeredmény helyett egy másik $\mathcal{X}$-beli pontba jussanak, ezért a stratégia egyensúlyi. 


\section{Többoldalú hozzárendelési játékok}

Ebben a részben a hozzárendelési játékok egy általánosításával, a többoldalú hozzárendelési játékokat vizsgáljuk. Itt a koalíciók értékét nem két- hanem $r(\geq 3)$ oldalú párosítások maximális értékeként kapjuk meg. Ez az általánosított osztály sok szempontból hasonló, mint a „sima” hozzárendelési játékok, de vannak alapvető különbségek is. Az két fontos különbség (a sok közül), hogy itt a játék magja lehet üres (Kaneko, 1982), valamint a „sima” hozzárendelési játékok esetén nagyon sokszor használt háló tulajdonságnak itt már az értelmezése sem egyszerü, valamint míg a 2 oldalú esetben a magnak volt vevő-, és eladóoptimális pontja, több oldal esetében ilyen már nem biztos hogy létezik (Tejada, 2011). A mag stabilitására Solymosi \& Raghavan (2001) által a sima hozzárendelési játékokra adott szükséges és elégséges feltételnek (1.2.1. tétel) csak a szükségessége látszik egyből, a bizonyítása is gyakorlatilag ugyanaz, mint a kétoldalú hozzárendelési játékok esetén. Solymosi \& Raghavan (2001) bizonyítása, valamint az dolgozatban az 1.2.1. tétel bizonyításában is kihasználtuk, hogy kétoldalú hozzárendelési játékkal van dolgunk. A legkisebb nem triviális $2+2+2$-es háromoldalú esetben Atay \& Núñez (2019) belátták, hogy a mátrix főátlódominanciája elégséges feltétele a stabilitásnak, de a bizonyításuk viszonylag bonyolult, és nem valószínü, hogy általánosítható nagyobb esetekre. Ebben a fejezetben saját eredményként belátjuk, hogy bármely többoldalú hozzárendelési játékban igaz, hogy a mag akkor és csak akkor stabil, ha a generáló (poli)mátrix foátlódomináns. A bizonyítás egyszerübb és rövidebb, mint Atay \& Núñez (2019) bizonyítása a nagyon speciális esetre, és a bizonyítást felhasználva könnyen kaphatunk egy algoritmust is, aminek segítségével a fóátlódomináns esetben bármely nem magbeli elemhez kaphatunk egy azt domináló mag-elosztást. A fejezet végén megmutatjuk, hogy a hozzárendelési játék magjának stabilitására az 1.2.1. tétel bizonyításának ötlete, miszerint ha egy vegyespáros aktív a mag valamely pontjában, akkor egy van olyan pontja is a magnak, ahol a vevő, és egy olyan is ahol az eladó kifizetése 0 és ezekben a pontokban szintén aktív a vegyespáros, a többoldalú hozzárendelési játékoknál egyedül a $2+2+2$-es esetben müködik. Ebben az esetben viszont ez adni is fog egy bizonyítást a fóátlódominancia elégségességére.

\subsection{Definíciók}

5.1.1. Definíció. Egy $(P ; v)$ játék többoldalú hozzárendelési játék, ha a játékosok halmazának van egy $P=N^{1} \cup N^{2} \cup \cdots \cup N^{r}$ partíciója, és található hozzá olyan nemnegatív 
$A=\left[a_{E}\right]_{E \in N^{1} \times N^{2} \times \cdots \times N^{r}}$ polimátrix, amelyre minden $S \subseteq P$ koalíció esetén

$$
v(S)= \begin{cases}0 & \text { ha } \exists i: N^{i} \cap S=\emptyset \\ v_{A}(S):=\max _{\mu \in \Pi\left(S \cap N^{1} ; S \cap N^{2} ; \ldots ; S \cap N^{r}\right)} \sum_{E \in \mu} a_{E} & \text { különben }\end{cases}
$$

Ahol $\Pi\left(X^{1} ; X^{2} ; \ldots ; X^{r}\right)$ az $X^{i}$ halmazok közti r-esitések halmaza.

A fenti definíció az $r=2$ esetben a „sima” kétoldalú hozzárendelési játékok osztályát adja.

A hozzárendelési játékokhoz hasonlóan a jelölések egyszerüsítése érdekében felteszünk néhány dolgot:

- Minden osztályban ugyanannyi játékos van, azaz $\left|N_{1}\right|=\left|N_{2}\right|=\cdots=\left|N_{r}\right|=n$. Ezt zéró-játékosok hozzávételével mindig el tudjuk érni.

- A főátlóban maximális értékű párosítás van. Ez is mindig elérhető, ha az osztályok elemeinek sorrendjét megváltoztatjuk. A föátló elemeit $\boldsymbol{d}$ vektorral jelöljük.

- A fóátlóbeli elemek csökkenő sorrendben jönnek, azaz $d_{i} \geq d_{j}$ ha $i<j$. Ez is elérhető az osztályok cseréjével.

- Azt a vektort, amelyben az $i$. osztály kivételével minden játékos kifizetése 0 , az i. osztály játékosai pedig éppen a fóátlóbeli értékeket kapják (azaz a maximális értékü párosításbeli értékeiket) $\boldsymbol{d}^{i}$-vel jelöljük.

\subsection{A mag stabilitása}

Az $A$ polimátrixhoz tartozó játék magját a hozzárendelési játékokéhoz hasonlóan $\mathcal{C}_{A^{-}}$val jelöljük. A későbbiekben a magegyenlőtlenséget megszegő koalíción, domináló koalíción stb mindig vegyes $r$-est értünk, mivel a hozzárendelési játékokhoz hasonlóan itt is az egyszemélyes koalíciók és a vegyes $r$-esek a hatékonyak, így ha egy elosztás dominál egy másikat, akkor dominálja egy vegyes $r$-esen keresztül is.

Megmutatjuk, hogy a kétoldalú hozzárendelési játékokhoz hasonlóan a mag akkor és csak akkor stabil, ha a játékot megadó polimátrix fóátlódomináns.

A hozzárendelési játékhoz hasonlóan az egyik az az irány triviális, hogy ha stabil a mag, akkor a mátrix fóátlódomináns. A bizonyítás is pontosan ugyanaz: tudjuk, hogy a fóátlóbeli elemekre a magegyenlőtlenségeknek egyenlőségre kell teljesülniük minden magelem esetén, így a $\boldsymbol{d}^{i}$ vektorokat $i=1,2, \ldots, r$ nem dominálja a mag. Ezek a vektorok pedig pontosan akkor elemei a magnak, ha a generáló mátrix fóátlódomináns. 
Nézzük a másik irányt, azaz ha a generáló polimátrix fóátlódomináns, akkor a játék magja stabil.

A bizonyítás során szükségünk lesz a következő két lemmára:

5.2.1. Lemma. Legyen A egy föátlódomináns polimátrix $\boldsymbol{x} \notin \mathcal{C}_{A}$ elosztásvektor, amely megszeg egy olyan $S$ vegyes $r$-eshez tartozó magegyenlötlenséget, amelynek jobb oldalán $d_{1}$ szerepel (a legnagyobb érték a mátrixban). Ekkor $\boldsymbol{x}$-et dominálja a játék magja.

\section{BIZONYÍTÁs.}

Mivel $\boldsymbol{d}^{i}$ magbeli és $\boldsymbol{d}^{i}(S)=d_{1}>\boldsymbol{x}(S)$ minden $i=1,2, \ldots, r$-re, ezért a $\boldsymbol{d}^{i}$ vektoroknak van olyan konvex kombinációjuk, amely dominálja $\boldsymbol{x}$-et.

5.2.2. Lemma. Legyen $A$ egy föátlódomináns polimátrix, $\boldsymbol{x} \notin \mathcal{C}_{A}$ elosztásvektor és $\boldsymbol{y} \leq \boldsymbol{x}$ szintén egy nemnegatív (jellemzöen nem elosztás) vektor.

Legyen $a_{S}^{\prime}=\max \left\{0 ; a_{S}-\boldsymbol{y}(S)\right\}$ a vegyes $r$-es $S$ koalíciókra, továbbá legyen $A^{\prime}$ az ezekböl összerakott polimátrix. (azaz A minden elemét csökkentjük annyival, amennyit $\boldsymbol{y}$-ban kapnak, de legfeljebb 0-ig).

Ha az $A^{\prime}$ mátrix is fóátlódomináns, és $\boldsymbol{x}$-et nem dominálja az A mátrixhoz tartozó játék magja, akkor $\boldsymbol{x}-\boldsymbol{y}$ egy olyan elosztás az $A^{\prime}$-höz tartozó játékban, amely nincs a játék magjában, és nem is dominálja a mag és fordítva. (Azaz A-ban az $\boldsymbol{x}$ ugyanúgy viselkedik, mint $A^{\prime}$-ben az $\boldsymbol{x}-\boldsymbol{y}$ ).

\section{BIZONYÍTÁS.}

Elosztás: $\boldsymbol{y} \leq \boldsymbol{x}$ miatt $\boldsymbol{x}-\boldsymbol{y}$ nemnegatív, és mivel továbbra is maximális értékű párosítás van a fóátlóban és a föátló elemeit összesen $\boldsymbol{y}(P)$-vel csökkentettük hatékony is.

Ha $\boldsymbol{x}$ megszeg egy magegyenlötlenséget az $A$-hoz tartozó játékban, akkor $\boldsymbol{x}-\boldsymbol{y}$ is megszegi ugyanazt az $A^{\prime}$-höz tartozó játékban, mivel az egyenlőtlenség mindkét oldalát ugyanannyival csökkentettük ez nyilván fordítva is igaz.

5.2.3. Tétel. Az A polimátrix pontosan akkor föátlódomináns, ha a hozzá tartozó többoldalú hozzárendelési játék magja stabil.

\section{BIZONYÍTÁS.}

Legyen $\boldsymbol{x}$ egy nem magbeli elosztásvektor. Ha $\boldsymbol{x}$ nem teljesít egy olyan magegyenlötlenséget, amelyhez $d_{1}$ érték tartozik (a mátrixban a legnagyobb fóátlóbeli elem), akkor 5.2.1. lemma miatt van a magnak olyan eleme, amely dominálja.

Ha minden ilyet teljesít, akkor legyen $K$ a $d_{1}$ érték(ek)hez tartozó játékosok halmaza, és legyen $\boldsymbol{x} \mid K$ az a vektor, amiben a $K$-beli játékosok ugyanazt kapják mint $\boldsymbol{x}$-ben a 
többiek 0-t.

5.2.2. lemmához hasonlóan csökkentsük $\boldsymbol{x}$-et és az $A$ mátrixot $\epsilon \cdot \boldsymbol{x} \mid K$-val, ahol $\epsilon$-t a lehető legnagyobbnak választjuk meg úgy, hogy még éppen ne legyen baj a fóátlódominanciával vagy éppen bővüljön a $K$ halmaz.

Valamilyen kis pozitív $\epsilon$ biztos jó lesz, mert csak a $K$-n belüli $r$-esekkel lehetne probléma (az összes nem $K$-beli $r$-eshez tartozó érték szigorúan kisebb volt mint $d_{1}$ ), amik valamely föátlón kívüli $d_{1}$ értékhez tartoztak. Ezekre viszont teljesültek a magegyenlőtlenségek, így legalább annyival csökkennek, mint a fóátlóbeli $d_{1}$ elemek. Nézzük meg mikor kell megállnunk:

- bővül a $K$ halmaz: ekkor bővítsük a halmazt készítsük el az új $\boldsymbol{x} \mid K$ vektort és folytassuk a csökkentést.

- valamelyik nem fóátlóbeli elem éppen annyi lesz, mint valamelyik hozzá tartozó fóátlóbeli elem. Ez a nem fóátlóbeli elem csak $K$ halmazon belüli lehet, és csak úgy fordulhat elő, hogy a kérdéses elem kevésbé csökkent mint a fóátló, ami azt jelenti, hogy megszegte a hozzá tartozó magegyenlőtlenséget. Ekkor viszont az új mátrixban találtunk egy elemet ami megszeg egy maximális mátrixelemhez tartozó egyenlőtlenséget, így 5.2.1. lemma miatt a csökkentett játék magja dominálja a csökkentett vektort, 5.2.2. lemma miatt ekkor az eredetiben is találunk, tehát kész vagyunk.

Véges sok lépés alatt végzünk, mivel vagy bővül a $K$ halmaz, vagy találunk domináló elemet.

12. Példa. A példa kétoldalú hozzárendelési játék, de pontosan ugyanígy megy többoldalúra is.

\begin{tabular}{c|ccc} 
& 2 & 6 & 3 \\
\hline 8 & 10 & 6 & 4 \\
2 & 0 & 8 & 2 \\
1 & 3,5 & 4 & 4
\end{tabular}

K-ban csak az elsö pár van benne így őket csökkentjük. A sorjátékos kifizetését 8€-nal az oszlopét 2є-nal.

Addig tudjuk csökkenteni, amíg a fóátlóbeli 10-es 8 nem lesz, azaz $\epsilon=\frac{2}{10}$ A következö \begin{tabular}{cc|ccc} 
& & 1,6 & 6 & 3 \\
\cline { 2 - 5 } mátrix és a dominálandó vektor: & 6,4 & 8 & 4,4 & 2,4 \\
2 & 0 & 8 & 2 \\
1 & 3,1 & 4 & 4
\end{tabular}

Most már az első két-két játékos van K-ban, igy ezeket csökkentjük. A sorjátékosokat 


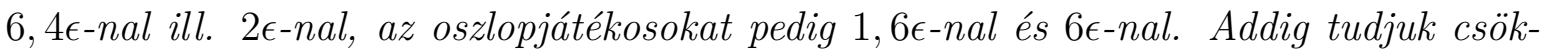
kenteni, amíg a fóátlóbeli 8-asokból 1-es lesz, azaz $\epsilon=\frac{1}{2}$

Az új mátrix és a dominálandó vektor:

\begin{tabular}{c|ccc} 
& 0,8 & 3 & 3 \\
\hline 3,2 & 4 & 0 & 0 \\
1 & 0 & 4 & 1 \\
1 & 2,3 & 1 & 4
\end{tabular}

K-nak már az összes játékos tagja, ezért a sorokat $(3,2 ; 1 ; 1) \epsilon$-nal, az oszlopokat

$(0,8 ; 3 ; 3) \epsilon$-nal csökkentjük, addig amíg a fóátlódominancia éppen el nem romlik, azaz a 2,3-as $a_{31}$ érték egyenlő nem lesz a fóátlóbeliekkel. Ez $\epsilon=\frac{17}{22}$-nél történik.

Az utolsó mátrix és dominálandó vektor: \begin{tabular}{c|cccc} 
& & $\frac{4}{22}$ & $\frac{15}{22}$ & $\frac{15}{22}$ \\
\cline { 2 - 5 } & $\frac{16}{22}$ & $\frac{20}{22}$ & 0 & 0 \\
$\frac{5}{22}$ & 0 & $\frac{20}{22}$ & 0 \\
& $\frac{5}{22}$ & $\frac{20}{22}$ & 0 & $\frac{20}{22}$
\end{tabular} Az utolsó játék magjában van az az elem, amelyben minden vevő $\frac{20}{22}$-et kap, az eladók 0-t és fordítva. Ennek a kettönek pl a számtani közepe (ahol mindenki $\frac{10}{22}$-et kap) dominálja a vektorunkat. Ezt visszatranszformálva az eredeti játékra a sorjátékosok kifizetései: $\frac{10}{22}+8-\frac{16}{22}=\frac{170}{22}$

$\frac{10}{22}+2-\frac{5}{22}=\frac{49}{22}$

$\frac{10}{22}+1-\frac{5}{22}=\frac{27}{22}$

Az oszlopjátékosoké: $\frac{10}{22}+2-\frac{4}{22}=\frac{50}{22}$

$\frac{10}{22}+6-\frac{15}{22}=\frac{127}{22}$

$\frac{10}{22}+3-\frac{15}{22}=\frac{61}{22}$

\section{3. $2+2+2$-es eset}

A legegyszerübb nem triviális többoldalú esetben, az olyan háromoldalú játékokban, ahol minden osztályban 2 játékos van többet is mondhatunk a mag szerkezetéről. az 1.2.1. tétel bizonyításában láttuk, hogy a hozzárendelési játékoknál, ha a generáló mátrix fóátlódomináns, és veszünk egy nem magbeli (fél)elosztást, akkor a mag minden olyan koalíción keresztül képes dominálni a kiválasztott vektort, amelyhez tartozó magegyenlőtlenséget a vektor megszeg, és valamely magelemre egyenlőségként teljesül. Meg fogjuk mutatni, hogy a magnak ez a tulajdonsága megvan a $2+2+2$-es többoldalú hozzárendelési játékokban is.

5.3.1. Állítás. $2+2+2$-es többoldalú hozzárendelési játékban ha a generáló mátrix föátlódomináns, akkor ha van olyan eleme a magnak, amelyre valamely vegyes hármashoz tartozó magegyenlötlenség egyenlöségként teljesül, akkor van a magnak három olyan ele- 
me is, amire ugyanez az egyenlötlenség szintén egyenlöségként teljesül, és a hármasból csak az egyik játékos kifizetése pozitív, a másik kettőé 0.

\section{BiZONYÍTÁs.}

Továbbra is a főátlóban van az optimális párosítás, az általunk választott egyenlőtlenség az $u_{i}+v_{j}+w_{k} \geq a_{i j k}$, ami az $(\boldsymbol{u} ; \boldsymbol{v} ; \boldsymbol{w})$ pontra egyenlöségként teljesül. Ha $i=j=k$, akkor nyilvánvalóan teljesül az állítás, mert $\boldsymbol{d}^{i}$-k pont ilyen pontok, így elég azzal foglalkozni, amikor $a_{i j k}$ nem fóátlóbeli elem. Feltehetjük, hogy az $A$ mátrixunk a következö alakú: $a_{p q r}=\min \left(u_{p}+v_{q}+w_{r} ; u_{1}+v_{1}+w_{1} ; u_{2}+v_{2}+w_{2}\right)$, azaz mintha minden egyenlőtlenséget egyenlőségre teljesítene (ez lenne ha csak az első tag lenne minimum nélkül), de hogy megtartsuk a fóátlódominanciát, ha valamelyik elem így nagyobb lenne mint az optimális párosításbeli, akkor azt lecsökkentjük. A definíciója miatt ez a mátrix nyilván fóátlódomináns, a principal sectione megegyezik az eredeti mátrixéval és a magja tartalmazza $(\boldsymbol{u} ; \boldsymbol{v} ; \boldsymbol{w})$-t. Az ilyen mátrixok közül pedig ez a legnagyobb. Éppen ezért az ehhez a mátrixhoz tartozó játék magja részhalmaza az eredeti játék magjának, így ha erre igaz az állítás, akkor az eredetire is.

Abban az esetben ha $a_{i j k}=a_{111} \leq a_{222}$, azaz a vizsgált egyenlőtlenség jobb oldala megegyezik valamelyik elemmel a fóátlóban, akkor könnyen tudunk megfelelö elosztást mutatni: mivel az $a_{i j k}$-t nem a fóátlóból vettük, $i, j, k$ közül valamelyik 1-es. Ebben az osztályban a második játékos kapjon $a_{222}-a_{111}$-et, majd a megfelelő osztály (amelyikben lévő játékosnak akarunk mindent adni az $a_{i j k}$-hoz tartozó egyenlőtlenségben) mindkét játékosának adjunk még $a_{111}$-et.

Fontos lesz számunkra, hogy a magbeli vektorban (amiből a mátrixot csináltuk) melyik volt a nagyobb koordináta. Ha mindenhol az 1-es (vagy mindenhol a 2-es) koordináta a nagyobb, akkor az $a_{i j k}$ vizsgált elem megegyezik a kisebb fóátlóbeli elemmel, amire már beláttuk az állítást.

Az ijk elemhez tartozó koordinátának legalább 2 esetben a kisebbek kell lenniük. Ez azért van, mert ha két koordináta is nagyobb lenne, akkor az $a_{i j k}$-hoz tartozó egyenlőtlenség (ami a feltevésünk szerint egyenlőségre teljesül) jobb oldalán nagyobb szám kellene, hogy álljon mint az egyik fóátlóbeli elem (a kisebbik koordináta szerinti fóátlóelemnél), ami ellentmondás.

Az $a_{i j k}$-hoz tartozó koordináták közül azokat, ahol kettő közül az a kisebb könnyen le tudjuk nullázni: szimmetria miatt tegyük fel, hogy $u_{i} \leq u_{j}$. Ekkor csökkentsük le $u_{i}$-t és $u_{j}$ koordinátáját $u_{i}$-vel, és növeljük meg $\boldsymbol{v}$ (vagy $\boldsymbol{w}$ ) mindkét koordinátáját 
ennyivel. Ez az elem nyilván magbeli lesz, mivel az összes magegyenlőtlenség bal oldala változatlan maradt.

Ebből következik, hogy ha az $a_{i j k}$-nál mindhárom koordináta a kettő közül a kisebb (vagy egyenlö) volt, akkor kész is vagyunk. Egyedül akkor van gond, ha valamelyik koordináta (azt már láttuk, hogy csak egy ilyen lehet) a nagyobbik volt. Tegyük fel tehát, hogy $u_{i}=u_{1} \wedge u_{2}$. $j$ és $k$ közül az egyik meg kell, hogy egyezzen $i$-vel, mivel ha mindkettő a másik koordináta lenne, akkor mindhárom helyen az $i$ koordináta lenne a nagyobb, amire már beláttuk az állítást. Ismét szimmetria miatt feltehetjük hogy $j=i$ és $k \neq i$. Csökkentsük le $u_{i}$-t és növeljük meg $v_{i}$-t $u_{i}-u_{k} \wedge v_{k}-v_{i}$-vel.

Az így kapott vektor magbeli, mivel nézzük meg melyik egyenlőtlenségek bal oldala csökkent: az $a_{i k i}$-hez és $a_{i k k}$-hoz tartozóké. Tudjuk viszont, hogy mindkettő szigorú egyenlőtlenségre teljesült, mivel ezeknél két illetve három helyen is a kettő közül a nagyobb koordináta volt, tehát a koalíció kifizetése szigorúan nagyobb volt, mint valamelyik főátlóbeli elem. Az $a_{i i k}$-hoz tartozó egyenlőtlenség pedig továbbra is egyenlőtlenségre teljesül. A kettő közül egyébént az $u_{i}-u_{k}$ kell, hogy a kisebb legyen, mivel ha nem az lenne, akkor az $a_{i j k}$ elem nagyobb lenne, mint az $a_{j j j}$ fóátlóbeli elem.

Most viszont már egy olyan mag-elosztásunk van, ahol az egyik osztályban a két koordináta megegyezik. Ekkor viszont igaz az állítás, mivel ha ha csak a másik két osztályt nézzük az egy sima hozzárendelési játék, amiben bárhogy elóáll az egyenlőség.

Most megmutatjuk, hogy a $2+2+2$-es az egyetlen érdekes többoldalú eset, amiben az 5.3.1. állítás teljesül. Mivel a játék magjában csak azok a játékosok kaphatnak pozitív kifizetést, akik minden maximális értékü hozzárendelésben résztvesznek, feltehető, hogy minden osztály azonos elemszámú.

5.3.2. Állítás. 5.3.1. állitás nem igaz $2+2+2+2$-es hozzárendelési játék esetén.

\section{BIZONYÍTÁs.}

Nézzük a következő mátrixot: $a_{1111}=a_{2222}=8, a_{2122}=2, a_{1122}=a_{2121}=6$, és az összes többi vegyes négyes értéke 0 .

Az $a_{2122}$-höz tartozó magegyenlőtlenség a $(4,0 ; 0,6 ; 0,2 ; 4,0) \in \mathcal{C}$-re egyenlőségre teljesül. Viszont minden $(\boldsymbol{u} ; \boldsymbol{v} ; \boldsymbol{w} ; \boldsymbol{x})$ magelemre, amelyre az $a_{2122}$ elemhez tartozó egyenlőtlenség aktív $u_{2}=v_{1}=0$.

Adjuk össze az $u_{1}+v_{1}+w_{1}+x_{1}=8, u_{2}+v_{1}+w_{2}+x_{2}=2, u_{1}+v_{1}+w_{2}+x_{2} \geq$ $6, u_{2}+v_{1}+w_{2}+x_{1} \geq 6$ egyenlőtlenségeket $1,2,-1,-1$ súlyokkal. Ekkor a következőt kapjuk: $u_{2}+v_{1}+w_{1}+x_{2} \leq 0$, tehát minden magelemre, ahol az $a_{2122}$-höz tartozó magegyenlőtlenség aktív $0=u_{2}=v_{1}\left(=w_{1}=x_{2}\right)$. 
5.3.3. Állítás. 5.3.1. állitás nem igaz $3+3+3$-as hozzárendelési játék esetén.

\section{BIZONYÍTÁs.}

Nézzük a következö mátrixot: $a_{111}=a_{222}=a_{333}=10, a_{322}=4, a_{122}=a_{312}=9$ és az összes többi vegyes hármas értéke 0 .

Az $a_{322}$-höz tartozó magegyenlőtlenség $\mathrm{Az}(5,6,0 ; 5,0,10 ; 0,4,0) \in \mathcal{C}$-re egyenlőségre teljesül. Viszont minden $(\boldsymbol{u} ; \boldsymbol{v} ; \boldsymbol{w})$ magelemre, amelyre az $a_{322}$-höz tartozó magegyenlőtlenség aktív $u_{3}=v_{2}=0$.

Adjuk össze az $u_{1}+v_{1}+w_{1}=10, u_{3}+v_{2}+w_{2}=4, u_{1}+v_{2}+w_{2} \geq 9, u_{3}+v_{1}+w_{2} \geq 9$ egyenlőtlenségeket $1,2,-1,-1$ súlyokkal. Ekkor a következőt kapjuk:

$u_{3}+v_{2}+w_{1} \leq 0$, tehát minden magelemre, ahol az $a_{322}$-höz tartozó magegyenlőtlenség aktív $0=u_{3}=v_{2}\left(=w_{1}\right)$. 


\section{Ábrák jegyzéke}

1. $2+2$ játékos stabil mag, elosztáshalmaz . . . . . . . . . . . . . . . . . . 16

2. $2+2$ játékos stabil mag, principal section . . . . . . . . . . . . . . . . . 16

3. $3+3$ játékos stabil mag . . . . . . . . . . . . . . . . . . . . . . 18

$4.2+2$ játékos nem stabil mag, principal section . . . . . . . . . . . . . . 19

$5 . \quad$ Háló ábra . . . . . . . . . . . . . . . . . . . . . . . 20

6. $\quad \mathcal{C} \mathcal{B}$ stabil bizonyítása 1 . . . . . . . . . . . . . . . . . . . . . . . 29

7. $\quad \mathcal{C B}$ stabil bizonyítása $2 \ldots \ldots \ldots$. . . . . . . . . . . . 30

8. $\quad \mathcal{C B}$ vetítés elött . . . . . . . . . . . . . . . . . . . . . . . . 31

9. $\quad \mathcal{C B}$ vetülete . . . . . . . . . . . . . . . . . . . . . . . . . . . . 32

10. Két $\mathcal{C B}$ stabil halmaz együtt . . . . . . . . . . . . . . . . . 33

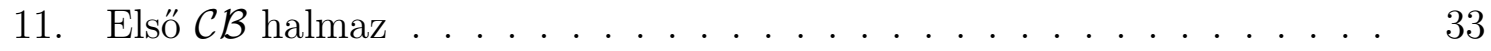

12. Második $\mathcal{C B}$ halmaz . . . . . . . . . . . . . . . . . . . . . . 34

13. Erösebb belsö stabilitás . . . . . . . . . . . . . . . . . . . . . . . . . . . 43

14. 2.1 .2 tétel bizonyítása 1 . . . . . . . . . . . . . . . . . . . . . 47

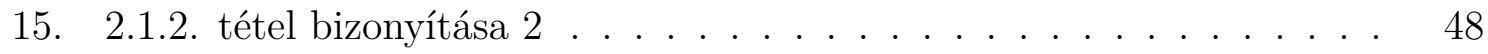

16. 2.1 .2 tétel bizonyítása 3 . . . . . . . . . . . . . . . . 50

17. Egyszerü többségi stabil halmaz 1 . . . . . . . . . . . . . . . . . . . . 52

18. Egyszerü többségi stabil halmaz 2 . . . . . . . . . . . . . . . . . . . . . 52

19. Egyszerü többségi $\mathcal{I}^{*}$-stabil halmaz 2 . . . . . . . . . . . . . . . . . . . 59

20. Konstrukció 1. lépés . . . . . . . . . . . . . . . . . . . . 65

21. Konstrukció 2. lépés . . . . . . . . . . . . . . . . . . . 65

22. Konstrukció 3. lépés . . . . . . . . . . . . . . . . . 66

23. $\mathcal{U}$ halmaz a 11 . példában . . . . . . . . . . . . . . . . . 74

24. X halmaz a 11 példában . . . . . . . . . . . . . . . . 75 


\section{Hivatkozások}

Atay, Ata. 2017. An alternative proof of the characterization of core stability for the assignment game. Operations Research Letters, 45(3), 217-219.

Atay, Ata, \& Núñez, Marina. 2019. A note on the relationship between the core and stable sets in three-sided markets. Mathematical Social Sciences, 98.

Bednay, Dezső. 2009. Stabil halmazok hozzárendelési játékokban. M.Phil. thesis, Budapesti Corvinus Egyetem. http://szd.lib.uni-corvinus.hu/1981/1/bednay_dezso.pdf Accessed on 2019-08-30.

Bednay, Dezső. 2012. Egyensúly és optimum. Tanulmányok Forgó Ferenc 70. születésnapjára. Budapest: Aula Kiadó. Chap. Alkuegyensúlyok és stabil halmazok, pages $3-12$.

Bednay, Dezső. 2014. Stable sets in one-seller assignment games. Annals of Operations Research, 222, 143-152.

Bondareva, Olga N., Kulakovskaya, T.E., \& Naumova, N.I. 1979. Solution of arbitrary cooperative four person games. Vestnik Leningradskogo Universiteta, Matematika, Mekhanika, Astronomija, 1979.

Diamantoudi, Effrosyni, \& Xue, Licun. 2006. Lucas Counter Example Revisited. Departmental Working Papers 2005-09. McGill University, Department of Economics.

Ehlers, Lars. 2007. Von Neumann-Morgenstern stable sets in matching problems. Journal of Economic Theory, 134, 537-547.

Gale, David, \& Shapley, Lloyd S. 1962. College Admissions and the Stability of Marriage. The American Mathematical Monthly, 69(1), 9-15.

Greenberg, Joseph. 1990. The Theory of Social Situations: An Alternative GameTheoretic Approach. Cambridge University Press.

Harsanyi, John C. 1974. An Equilibrium-Point Interpretation of Stable Sets and a Proposed Alternative Definition. Management Science, 20(11), 1472-1495.

Kaneko, Mamoru andWooders, Myrna Holtz. 1982. Cores of partitioning games. Mathematical Social Sciences, 3(4), 313 - 327.

Lucas, William F. 1968a. A game with no solution. Bull. Amer. Math. Soc., 74(2), $237-239$. 
Lucas, William F. 1968b. On Solutions for n-Person Games.

Lucas, William F. 1971. Some Recent Developments in n-Person Game Theory. SIAM Review, 13(4), 491-523.

Lucas, William F. 1992. Chapter 17 Von Neumann-Morgenstern stable sets. Handbook of Game Theory With Economic Applications, 1, 543-590.

Nash, John F. 1953. Two-Person Cooperative Games. Econometrica, 21(1), 128-140.

Nash, John F. 1958. Games and Decisions: Introduction and Critical Survey. Vol. 121.

Núñez, Marina, \& Rafels, Carles. 2013. Von Neumann-Morgenstern solutions in the assignment market. Journal of Economic Theory, 148(3), 1282-1291.

Peleg, Bezalel. 1986. A proof that the core of an ordinal convex game is a von NeumannMorgenstern solution. Mathematical Social Sciences, 11(1), 83-87.

Schotter, Andrew. 1974. Auctioning Bohm-Bawerk's Horses. International Journal of Game Theory, 3, 195-215.

Shapley, Lloyd S. 1959. Contributions to the Theory of Games (AM-40), Volume IV. Princeton University Press.

Shapley, Lloyd S. 1971. Cores of convex games. International Journal of Game Theory, $\mathbf{1}(1), 11-26$.

Shapley, Lloyd S, \& Shubik, Martin. 1969. On market games. Journal of Economic Theory, 1(1), 9-25.

Shapley, Lloyd S, \& Shubik, Martin. 1972. The assignment game I: The core. International Journal of Game Theory, 1, 111-130.

Shubik, Martin. 1984. A Game Theoretical Approach to Political Economy. Cambridge, MA: MIT Press.

Solymosi, Tamás. 2007. Kooperatív játékok (elektronikus jegyzet). http://gametheory.uni-corvinus.hu/Solymosi-KooperativJatekok-2007maj31.pdf Accessed 2019-08-28.

Solymosi, Tamás, \& Raghavan, T. 2001. Assignment Games with Stable Core. International Journal of Game Theory, 30, 177-185. 
Suk-Young, Chwe Michael. 1994. Farsighted Coalitional Stability. Journal of Economic Theory, 63(2), 299-325.

Tejada, Oriol. 2011. A theoretical study on assignment markets, power indices and taxation. Ph.D. thesis, Universitat de Barcelona.

Von Neumann, John, \& Morgenstern, Oskar. 1944. Theory of games and economic behavior. Princeton University Press Princeton.

Wako, Jun. 2010. A Polynomial-Time Algorithm to Find von Neumann-Morgenstern Stable Matchings in Marriage Games. Algorithmica, 58, 188-220.

Weber, Robert J. 1977. Probabilistic Values for Games. Cowles Foundation Discussion Papers 471R. Cowles Foundation for Research in Economics, Yale University. 